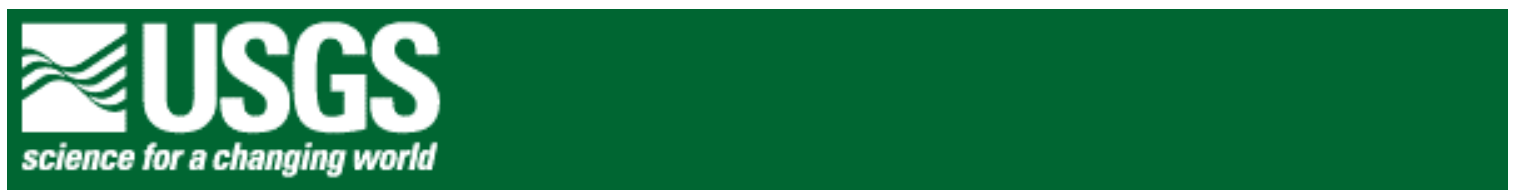

\title{
Geology of Badlands National Park: A Preliminary Report
}

By Philip W. Stoffer ${ }^{1}$

\section{Open-File Report 03-35}

\section{3}

This report is preliminary and has not been reviewed for conformity with U.S. Geological Survey editorial standards or with the North American Stratigraphic Code. Any use of trade, product, or firm names if for descriptive purposes only and does not imply endorsement by the U.S. Government.

U.S. Department of the Interior U.S. Geological Survey

${ }^{1}$ U.S. Geological Survey, Menlo Park, California 


\section{Table of Contents}

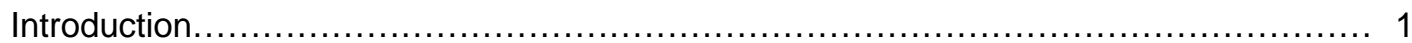

How the Badlands became a national park ...................................... 1

Maps of Badlands National Park ................................................ 2

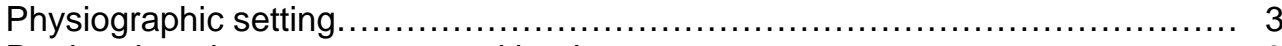

Regional geology, structure, and landscape..................................... 3

Geologic time scale.............................................. 3

Ancient rocks and structures........................................... 4

The Western Interior Seaway ............................................... 6

The Tertiary "White River" world ...................................... 6

The Quaternary landscape............................................. 7

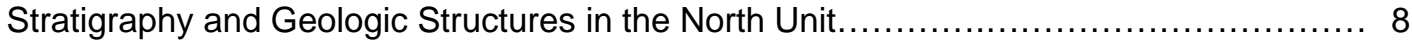

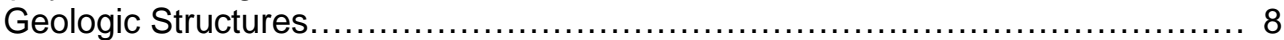

Composite Stratigraphic Section................................................. 9

Cretaceous Geology of Badlands National Park ........................................... 12

Resolving Cretaceous geology through paleontology.............................. 12

Cretaceous stratigraphy of Badlands National Park ................................ 14

Pierre Shale............................................................ 14

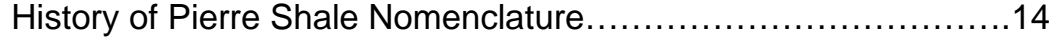

DeGrey facies.................................................. 15

Verendrye facies.................................................17

The Campanian-Maestrichtian boundary unconformity............. 21

Virgin Creek facies............................................. 22

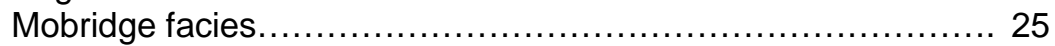

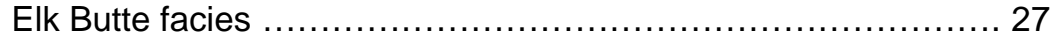

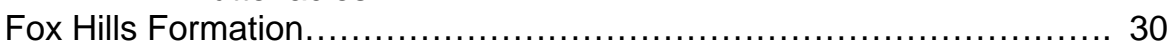

The Cretaceous-Tertiary boundary in Badlands National Park .............................. 35

A historical perspective on the Interior Zone ............................. 36

The Disturbed Zone............................................................ 37

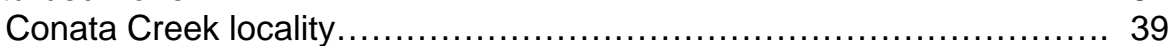

Grassy Tables Overlook locality .......................................40

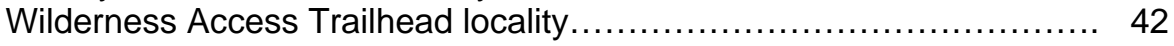

Buffalo Gap National Grasslands locality............................. 43

Dry Creek locality..................................................... 44

Unnamed marine facies (upper Fox Hills Formation)............................ 44

Tertiary Geology of Badlands National Park........................................... 46

Historical overview of the White River Group...................................... 47

The Yellow Mounds and Interior paleosols ........................................ 47

Chamberlain Pass Formation.................................................. 49

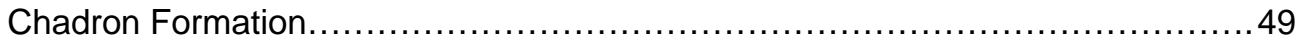

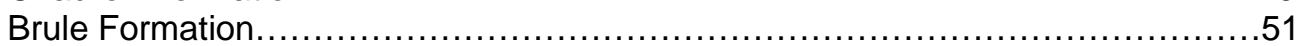

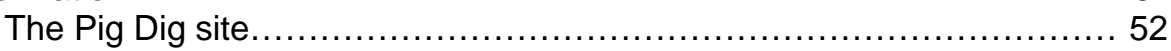

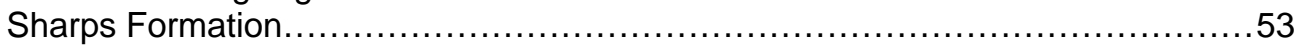

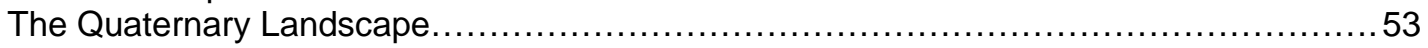

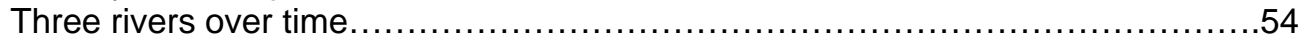

Stream terraces: can they tell us about past climatic conditions? ................... 55

Quaternary and late Tertiary time scale (stages and stades) $\ldots \ldots \ldots \ldots \ldots \ldots \ldots \ldots \ldots 5$

Weathering, mass wasting, and erosion........................................ 57

Castles, monuments, sod tables, and hoodoos................................ 59

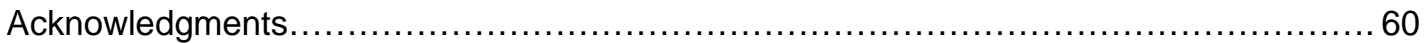

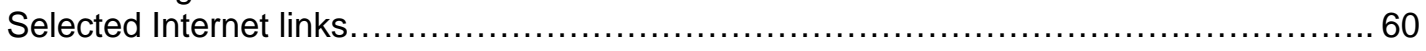

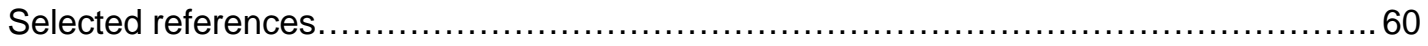




\section{Introduction}

Badlands National Park is host to perhaps the most scenic geology and landscape features in the Western Interior region of the United States. Ongoing erosion that forms the "badlands" exposes ancient sedimentary strata (fig. 1). This report provides a basic overview of the geology of the park. The discussions presented within include both wellestablished concepts and theories and new, preliminary data and interpretations. Much emphasis is placed on presenting information about the oldest and least studied rocks in the park (those that underlie the White River beds throughout the park region). A reference list provided includes many important published sources used in the preparation of this report. However, the volume of literature about the geology and paleontology of the Badlands region is immense, probably in range of thousands of publications.

\section{How the Badlands Became a National Park}

Although travelers and homesteaders called them "badlands" because of their rugged, desolate appearance and their lack of value for farming, the scenic descriptions these people returned east with added to the romantic call of the West. The value of the Badlands' paleontological resources was recognized in the early stages of exploration of the Nebraska Territory. Numerous fossil-collecting expeditions early in last century resulted in compilation of research and display collections in eastern American field museums. A perusal of the geologic literature of the Badlands region

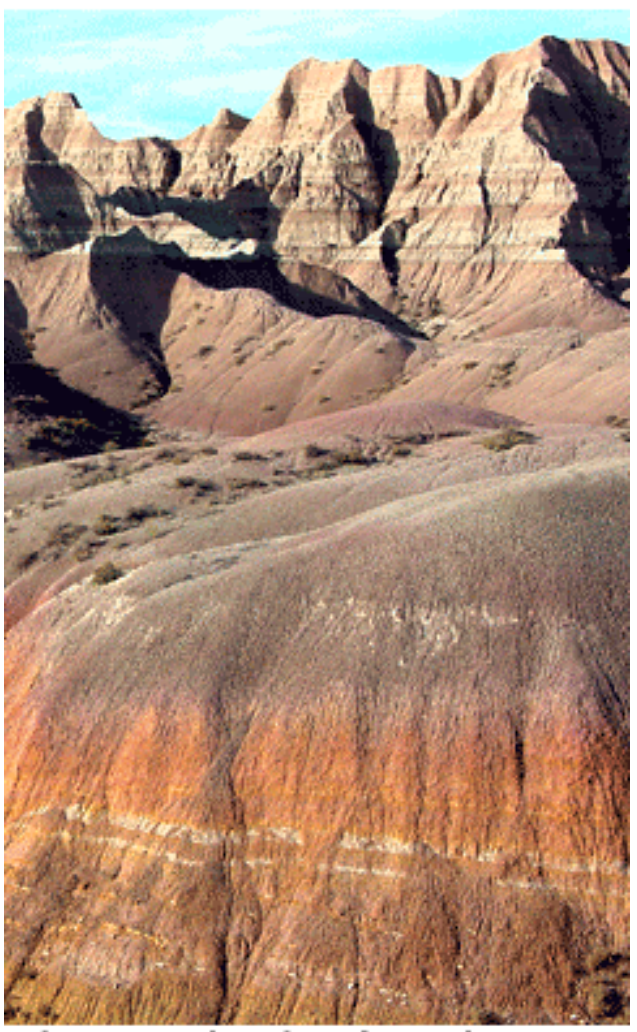

Figure 1. The view from the Rainbow Colors Overlook along the Badlands Loop Road encompasses exposures of strata of Late Cretaceous to middle Tertiary age. through time tells a story of changing thoughts and attitudes towards the land and its resources. Historically, research in the Badlands has focused on the fossil-rich terrestrial deposits (bone beds) of the Tertiary White River Group. Unfortunately, enthusiasm by amateur, private, and commercial collectors lead to the perceived over-exploitation of these resources, especially after a rail line linked the South Dakota towns of Interior and Scenic to the main rail lines in Rapid City. Efforts to preserve the uniquely scenic geologic setting led to the establishment of Badlands National Monument in 1929. Badlands became a national park by an Act of Congress in 1978 (see location maps, figs. 2 and 3). Today, all fossil, rock, plant, and animal resources are protected in the park and must remain where you find them. 


\section{Maps of Badlands National Park}

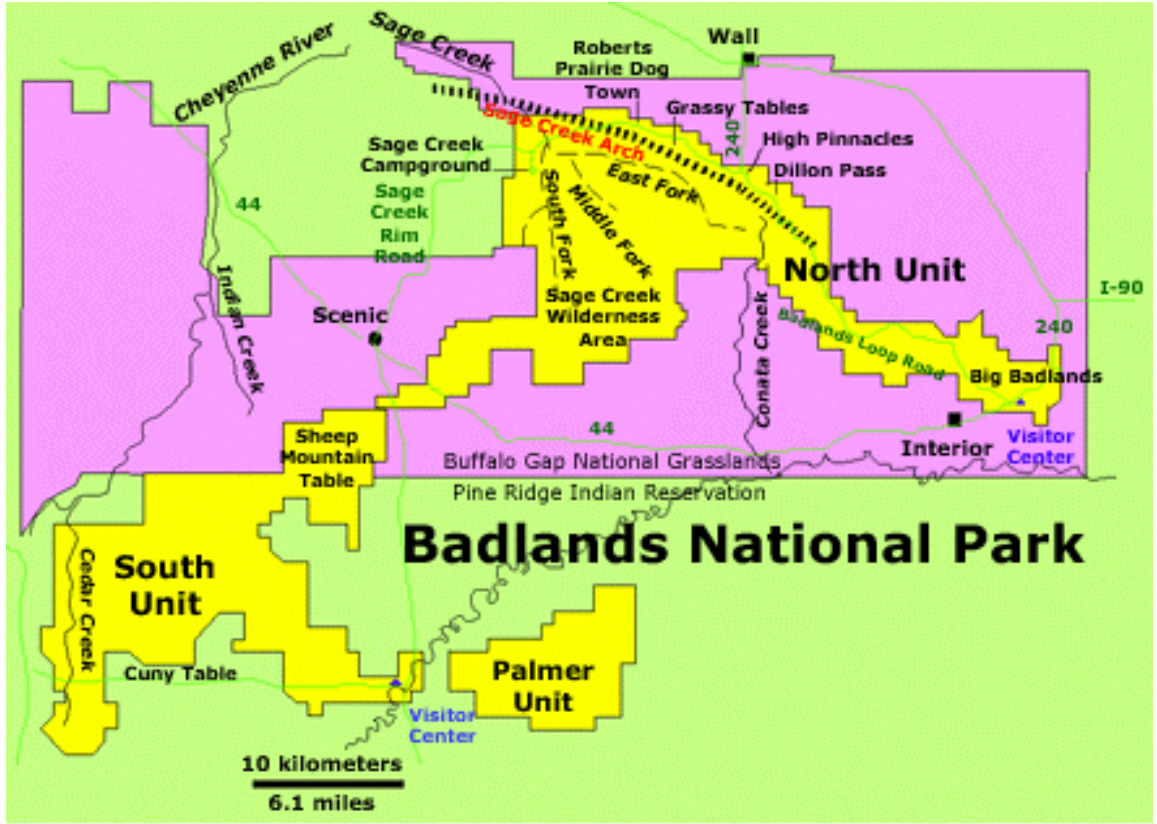

Figure 2. Map of Badlands National Park showing selected areas discussed in this report.

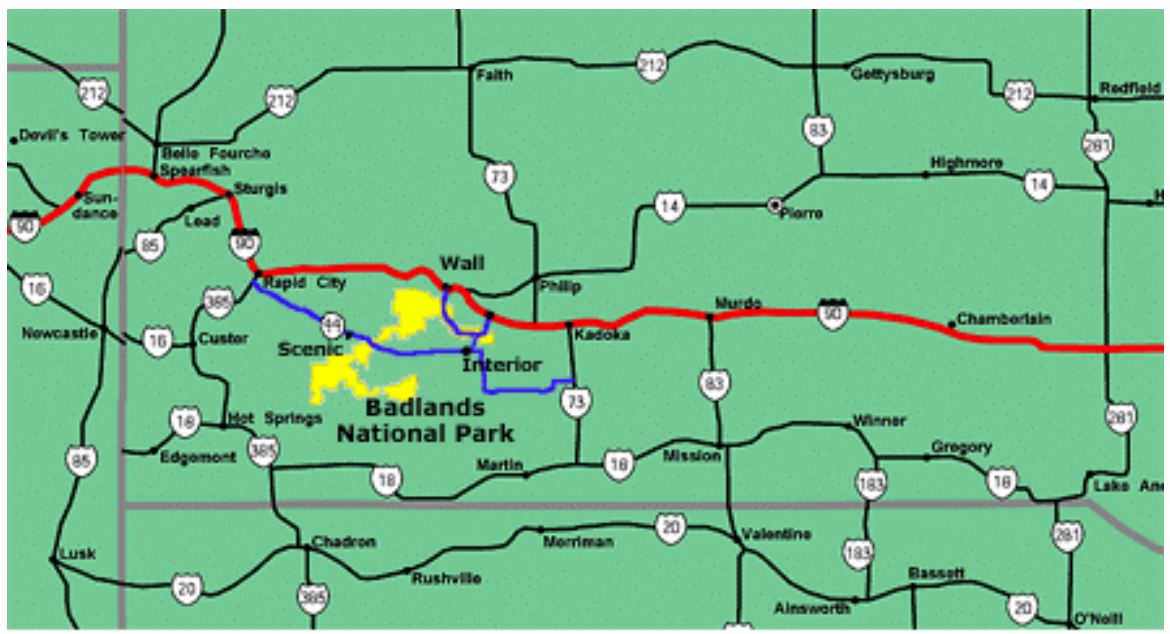

Figure 3. Road map of Badlands National Park region. 


\section{Physiographic Setting}

Badlands National Park is located on the high Great Plains of southwestern South Dakota east of the Black Hills. The highest elevation in the park is $3282 \mathrm{ft}(1000 \mathrm{~m})$ on Sheep Mountain; the lowest elevation is 2460 $\mathrm{ft}(750 \mathrm{M})$ along Sage Creek along the northern park boundary. The park receives an average of between 15 and 16 inches of rain per year, mostly in the form of thunderstorm activity that peaks in late June. By comparison, only a trace of precipitation occurs during the fall and winter months. The average high temperature for the month of July is around 91 degrees $\mathrm{F}$ (with some days rising into the 100s); January averages a low of 32 degrees $F$ (with some lows in the sub zero range). These climatic conditions are the essential ingredients of the American short grass prairies (or steppes) of the high plains. These climatic conditions unite with the local geologic setting to form the essential ingredients for the formation of "badlands" topography. The cold, dry winters and the hot summers limit the vegetation to short grasses and sedges on sunny exposures, to juniper and shrub oak communities in the cooler, shady, and wetter areas along ravines.

By comparison, the terrestrial strata of the White River Group lacks the essential nutrients for plants, whereas the underlying Cretaceous marine shale beds are rich in phosphorus, potassium, and iron. As a consequence, the Cretaceous strata are generally very poorly exposed beneath thick ground cover except along stream cut banks. In contrast, the White River beds form the steep upper hillsides of mostly barren white, red, and gray strata. Infrequent summer thunderstorms loosen and quickly erode the poorly consolidated sediments resulting in the development of badlands-style topography along escarpments. In the badlands region, escarpments have developed along the valleys of the White and Cheyenne River valleys and their tributaries. These escarpments formed in association with Quaternary erosion cycles - the episodic rapid down cutting by streams during wet periods followed by the gradual expansion of flood plains during dry periods. The Badlands Escarpment in the North Unit is also controlled in part by gradual on-going uplift along faults.

\section{Regional Geology, Structure, and Landscape}

The spectacular landscape in Badlands National Park is a reflection of ongoing erosional forces carving bedrock consisting of sedimentary rock formations. The exposed sedimentary strata preserve a record of more ancient geologic events and processes including changing depositional environments and the tectonic uplift and folding of rock layers in the Earth's crust. These strata and the fossils they preserve reveal evidence for gradual changes in the regional and global Earth system (such as uplift of the Rocky Mountains or changes in sea level and climate over time) or distant catastrophic events (such as the effects massive volcanic eruptions or asteroid impacts). A significant physiographic factor influencing the landscape of Badlands National Park is its proximity to rivers draining the high plains east of the Black Hills. The core of the "badlands" (meaning the "badlands" associated with Badlands National Park) is part of a dissected plateau region bounded by the Cheyenne River (to the north and west), the Bad River (to the east), and the White River (to the south). The word, badlands, applies to any region where erosion in poorly consolidated sediments creates a rugged and barren landscape.

\section{Geologic Time Scale}

Fig. 4 is a general geologic time scale that shows named divisions of time used in North America. This table only provides detail for geologic names used in this report. Geologic time is subdivided into unit rank from largest to smallest time intervals: era, period, epoch. Epochs are also subdivided into stages (some of these smaller subdivisions are mentioned later in the text); epochs are only shown for the Cretaceous and younger periods on Fig 4. Subdivisions of Precambrian time are not shown. 


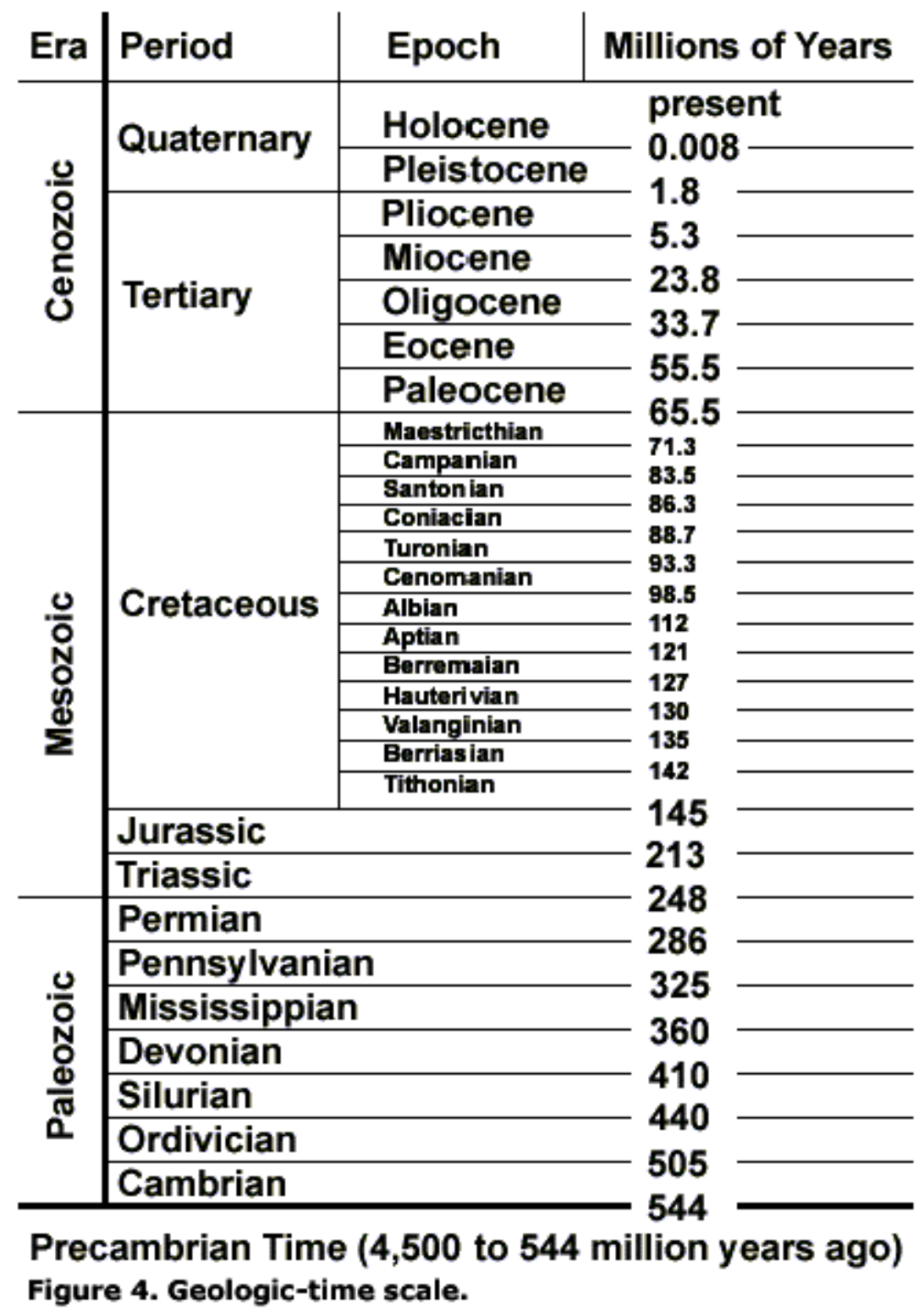

\section{Ancient Rocks and Structures}

The sedimentary layers exposed at the surface in the area are only a fraction of a thick blanket of sedimentary rock formations that blanket the high Great Plains region (fig. 5). Sedimentary rocks overlie a "basement" of even more ancient crust consisting of igneous and metamorphic rocks, similar to those exposed throughout the core of the Black Hills, or in smaller exposures east of the Missouri River or in the Canadian Shield region far to the northeast. The age of these basement rocks is measured in billions of years. Wells drilled in search of water and petroleum reveal that the blanket of sedimentary rock above the basement ranges varies in thickness across the region. Over time, in regions where the bedrock sank sedimentary basins formed. Areas where the land rose or folded upward are called arches or uplifts. 


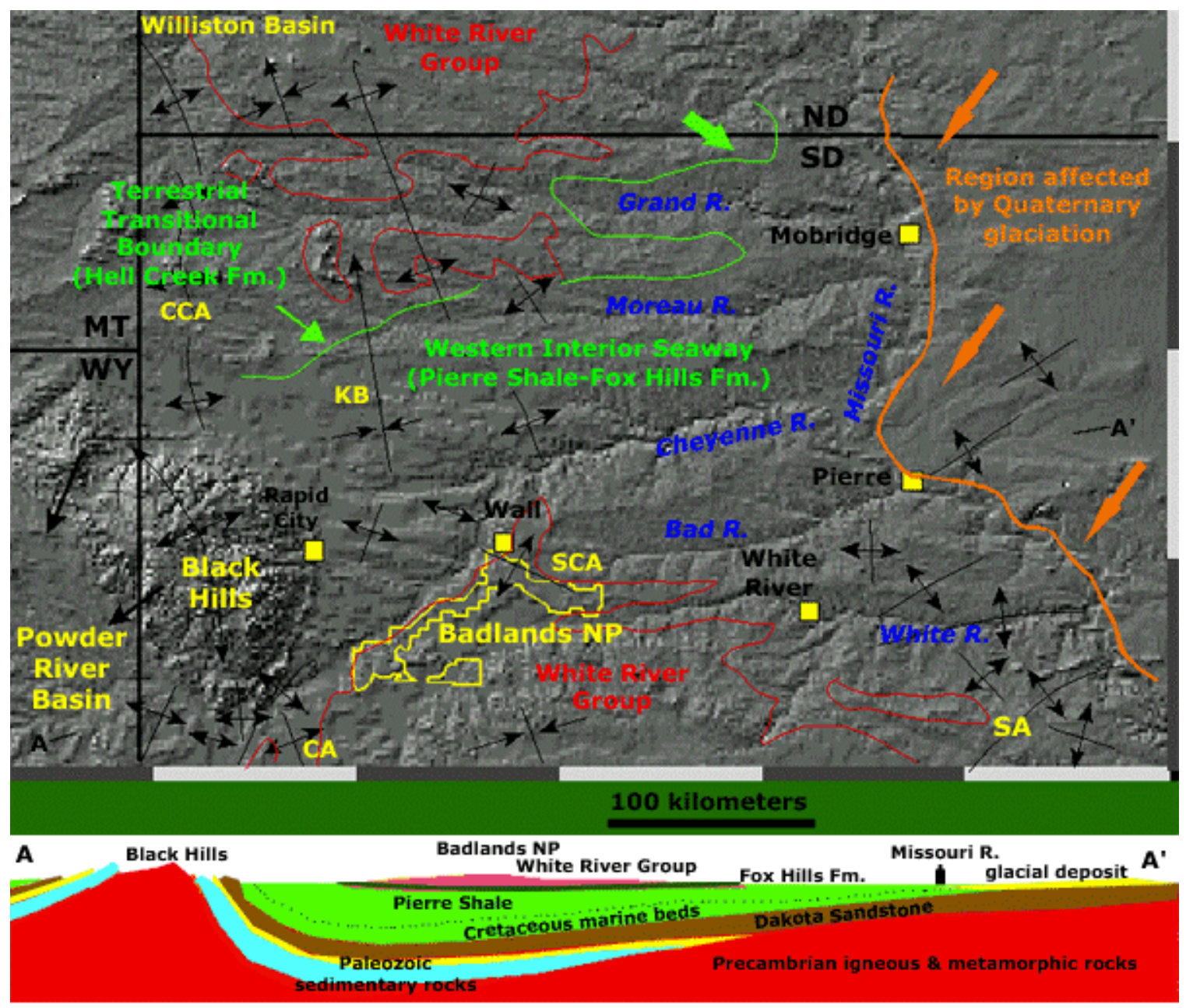

Figure 5. A regional geologic cross section of the Badlands National Park region and map showing selected geologic features with significance to discussions within this report. (abbreviations: SCA - Sage Creek Arch; KB - Kennedy Basin; CA - Chadron Arch; CCA - Cedar Creek Anticline; and SA - Siouxana Arch).

This blanket of sedimentary material that overlies the ancient basement rocks began to accumulate nearly half a billion years ago as erosion allowed the advance of the Cambrian sea across the region. Over the next half billion years, shallow seas advanced and retreated across the region many times as the land gradually rose or sank. The sedimentary blanket is thickest in regions where the land subsided relative to surrounding regions. Deep sedimentary basins in the region include the Williston Basin (in North Dakota and Montana) and the Powder River Basin (in eastern Wyoming). In portions of these basins, the sedimentary sequence is over 4,000 meters thick. However, in the Badlands National park area this sedimentary blanket is only about 1,000 meters thick. Records from oil drilling on anticlines such as the Cedar Creek Arch (in northwestern South Dakota) reveal that some basins and intervening uplifts formed gradually over time, whereas others grew in relatively short "pulses" such as occurred with the initial uplift of the modern Rocky Mountains (including the Black Hills) that began rising about 70 million years ago. As the Black Hills rose, erosion gradually stripped away materials. Today we can see a profile of this great sedimentary blanket in an outcrop belt of hogbacks along the flanks of the Black Hills. Water well drilling in the park area reveals that many of the same rock units exposed along the eastern flank of the Black Hills also occur beneath the park.

The geologic setting of the park's North Unit is controlled in part by the Sage Creek Arch, a long southeast-to-northwest-trending system of folds and faults that roughly parallels the park's northern boundary. Many other structural features are known throughout the region. As these uplifts developed, they 
influenced the pattern of sediment deposition across the region through time. The rock record for the Paleozoic Era (between 570 and 230 million years ago) is dominated by limestone formations formed from calcareous sediments deposited in shallow seas. Starting in the late Paleozoic, uplift in the region began to generate large quantities of clastic sediments (mostly sand and clay) that filled in basins across the region.

Through the Triassic and Jurassic Periods of the Mesozoic Era additional sediments were episodically deposited across the Badlands region. Rivers draining westward for the Appalachian region drained into a low, subdued landscape. Sedimentary rocks of the Triassic and Early Jurassic are "red beds" - typically consisting of layers of mudrock, sandstone, and gypsum deposited in a hot, arid, subtropical climate. By Jurassic time, the Cordilleran Mountain belt was actively developing. The development of the volcanic chains, such as those that formed the ancestral core or the Sierra Nevada, eventually blocked westward draining river systems. Ongoing volcanism and mountain building along the West Coast began the events that lead to the formation of the Western Interior Seaway in the Cretaceous Period.

\section{The Western Interior Seaway}

The oldest rocks exposed in the park formed from sediments deposited nearly 75 million years ago in the Western Interior Seaway, a broad, shallow inland sea that once extended from the Gulf of Mexico to the Arctic Ocean. At its maximum extent roughly 80 million years ago, this shallow inland sea extended from the Arctic Ocean to the Gulf of Mexico, and from the Wyoming/Idaho border region to perhaps the Mississippi Valley region (fig. 6). This seaway gradually vanished as the rising Rocky Mountains progressively flooded the region with sediments and the land rose above sea level. These strata consist of dark shale beds that contain remains of extinct species of marine organisms. These sediments, and other similar exposures across the region demonstrate that a great shallow seaway persisted across central North America.

Marine waters began flooding the mid-continent region nearly 115 million years ago (during the Early Cretaceous) as the Cordilleran mountain chain developed along the western margin of North America. This great seaway persisted for an additional 50 million years. In its final stages, sediment pouring into the seaway basin from the developing western mountain ranges caused the final eastward migration of the western shoreline. About this time, the last great dinosaurs of the Late Cretaceous (i.e., Tyrannosaurus and Triceratops) lived on a floodplain as the shoreline migrated into northwestern South Dakota, but marine conditions persisted in the Badlands region. These floodplain deposits are preserved as the Hell Creek Formation in northwestern South Dakota, Montana, and North Dakota, whereas the equivalent marine rocks make up the Fox Hills Formation and Pierre Shale in central South Dakota.

Then a great catastrophe occurred. At least one great asteroid collided with Earth around 65 million years ago, causing a great mass extinction. On land, all dinosaurs and flying reptiles vanished, and in the sea, the ammonites, mosasaurs (large swimming reptiles), and other groups disappeared. The seaway eventually completely disappeared from the region, and a whole new terrestrial ecosystem took its place.

\section{The Tertiary "White River" World}

During the early Tertiary, the landscape was dominated by broad, forested floodplains of ancient river systems draining from the west. Through the middle to late Tertiary, the landscape grew progressively higher and drier, yet still received sediments from the west, including ash falls from volcanic eruptions in the Western Cordilleran region (now the Nevada region). Terrestrial sedimentation during the early to mid Tertiary is responsible for the formation of the White River Group, the group of rock formation exposed in the "badlands" throughout the park region. The oldest sedimentary deposits of the White River Group 
formed in the Eocene Epoch, but the majority of the rock units formed during the following Oligocene Epoch. The youngest White River beds preserved in the park were deposited around 23 million years ago.

By about 50 million years ago, smaller brackish-water remnants of the Western Interior Seaway had completely vanished from the region, and a broad, low plain replaced it. Unlike today, the climate was warm and humid with abundant rainfall, producing a forested subtropical environment. Starting around 40 million years ago, sediments derived from the ancient core of the Black Hills and other areas began to fill in the broad low valleys that had developed across the landscape. River channel deposits and floodplain sediments accumulated, and the soils formed from them. With dinosaurs out of the way, mammalian species began to spread and diversify. During the Oligocene Epoch (35-23 million years ago) many large mammals adapted to the Badlands region. Many had appearances similar to modern species: Some resembled deer-like creatures (Leptomeryx), a giant pig (Archaeotherium), small horses (Mesohippus), a saber-tooth cat (Hoplophoneus), rhinoceros/hippopotamus-like creatures (Subhyracodon and Metamynodon), squirrel-like (Ischromys), burrowing sheep-like animals (Oreodon), and a rabbit-like rodent (Paleolagus). In addition, fish, turtles and other reptiles and birds flourished.

Although volcanoes in the western states had dumped ash across the region many times throughout time, in the late Oligocene several massive volcanic eruptions in the Nevada region dumped thick blankets of ash in the badlands region. Also in the late Oligocene the climate began to change, becoming drier as the land steadily began to rise. The record of sedimentation ends in the region in early Miocene time (around 20 million years ago).

The White River beds in Badlands National Park consist of a group of several rock formations, each with unique sedimentary rocks and fossil flora and fauna. Named rock subdivisions within the Tertiary White River Group exposed in the park include from oldest to youngest: the Chamberlain Pass Formation (Eocene), the Chadron Formation (Eocene), the Brule Formation (Oligocene), and the Sharps Formation (Oligocene).

\section{The Quaternary Landscape}

From the late Tertiary through today erosion has dominated the landscape while the entire region slowly continues to rise. Although continental glaciers of the Quaternary period did not reach the Badlands area, their influence on the river systems indirectly influenced the pattern of river drainages in the region. Climatic conditions in combination with bedrock characteristics are responsible for the formation of unusual badlands topography throughout the park region.

Although deposition of sediments probably continued in the park region after deposition of the Sharps Formation (late Oligocene, about 23 million years ago), erosion has removed all evidence of younger Tertiary deposits (however, deposits of Miocene and younger age do occur in the region). Many of the landscape features we see today owe their origin to processes that have taken place over the last several million years. On the highest hilltops in the park are coarse gravel deposits consisting of material derived from stream deposits formed when the surface of the landscape was much higher than today. Erosion now dominates the landscape. In most areas, hundreds of meters of sediment have been stripped away by erosion. The modern topographic distribution of the Badlands is a reflection the stream drainage patterns, vegetation, and climatic conditions that have changed over time.

The Quaternary Epoch began about 2 million years ago. In this time interval great continental glaciers developed in northern Canada and throughout the Rocky Mountain region. Several times continental glaciers spread from Canada as far south as Nebraska and Kansas. Although these glaciers did not reach the Badlands, they did change the river drainage pattern of the continent. Prior to these "ice ages", the major river systems that drained the mid continent flowed northward into Hudson Bay. As the continental glacier formed, large lakes developed along the southern boundary of the ice sheets (the modern Great Lakes, although analogous, are tiny by comparison). These lakes eventually filled to capacity and then poured over divides, spilling southward into the Mississippi River valley. The modern Missouri and Ohio Rivers 


\section{Stratigraphy and Geologic Structures in the North Unit}

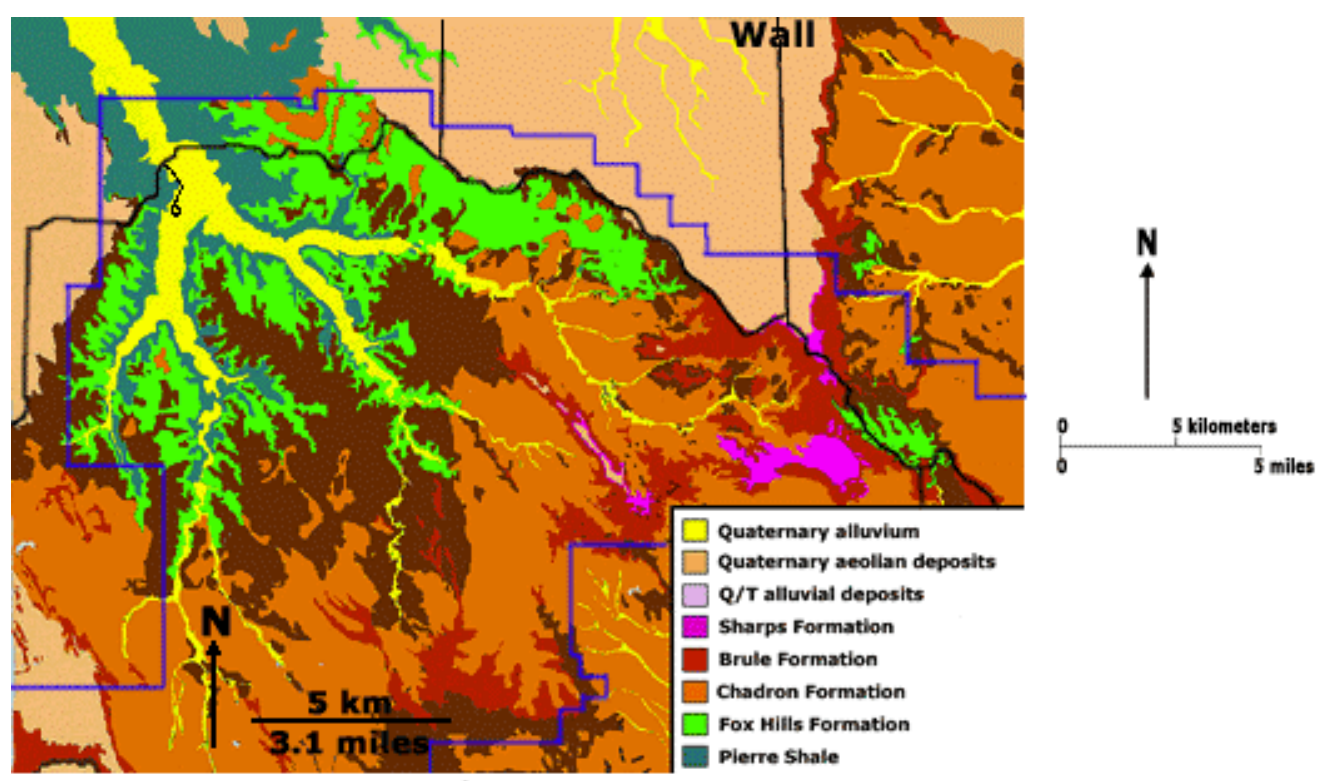

Figure 7. Geologic Map of the Sage Creek Wilderness Area and environs in the park's North Unit (Modified after Raymond and King, 1976). Colors are coded to named Cretaceous and Tertiary rock formations, Quaternary and Tertiary (Q/T) alluvial deposits, and Quaternary aeolian deposits and alluvium. Most of the discussion in this report focuses on this region. The blue line marks the park boundary.

\section{Geologic Structures}

In most areas around Badlands National Park the bedrock consists of flat lying (or nearly flat lying) sedimentary strata (see figs. 7 and 8 ). Faults in the park area typically only display measurable offsets in the range of several meters. In the North Unit of the park a large northwest-to-southeast-trending system of folds and faults defines one of the region's more prominent structures, the Sage Creek anticline/fault system (SCAFS). In some places the SCAFS consists only of a fault, in other places it consists of both folds and faults, some of which diverge from the overall trend in the system. The eastern end of SCAFS begins in the vicinity of the Big Badlands (in the eastern end of the North Unit) and is partly be responsible for the south-facing Badlands escarpment in that region. The anticline is perhaps most visible in the vicinity of the upper drainages of Conata Creek along the Badlands Loop Road (see below). The SCAFS basically parallels the Sage Rim Road in the western part of the North Unit. South and west of the Wilderness Access Trailhead area, the SCAFS forms the north limb of a gently southward-dipping monocline that essentially flattens into horizontal bedding south of the East Fork of Sage Creek. The SCAFS looses its surficial expression west of Sage Creek. 


\section{Composite Stratigraphic Section}

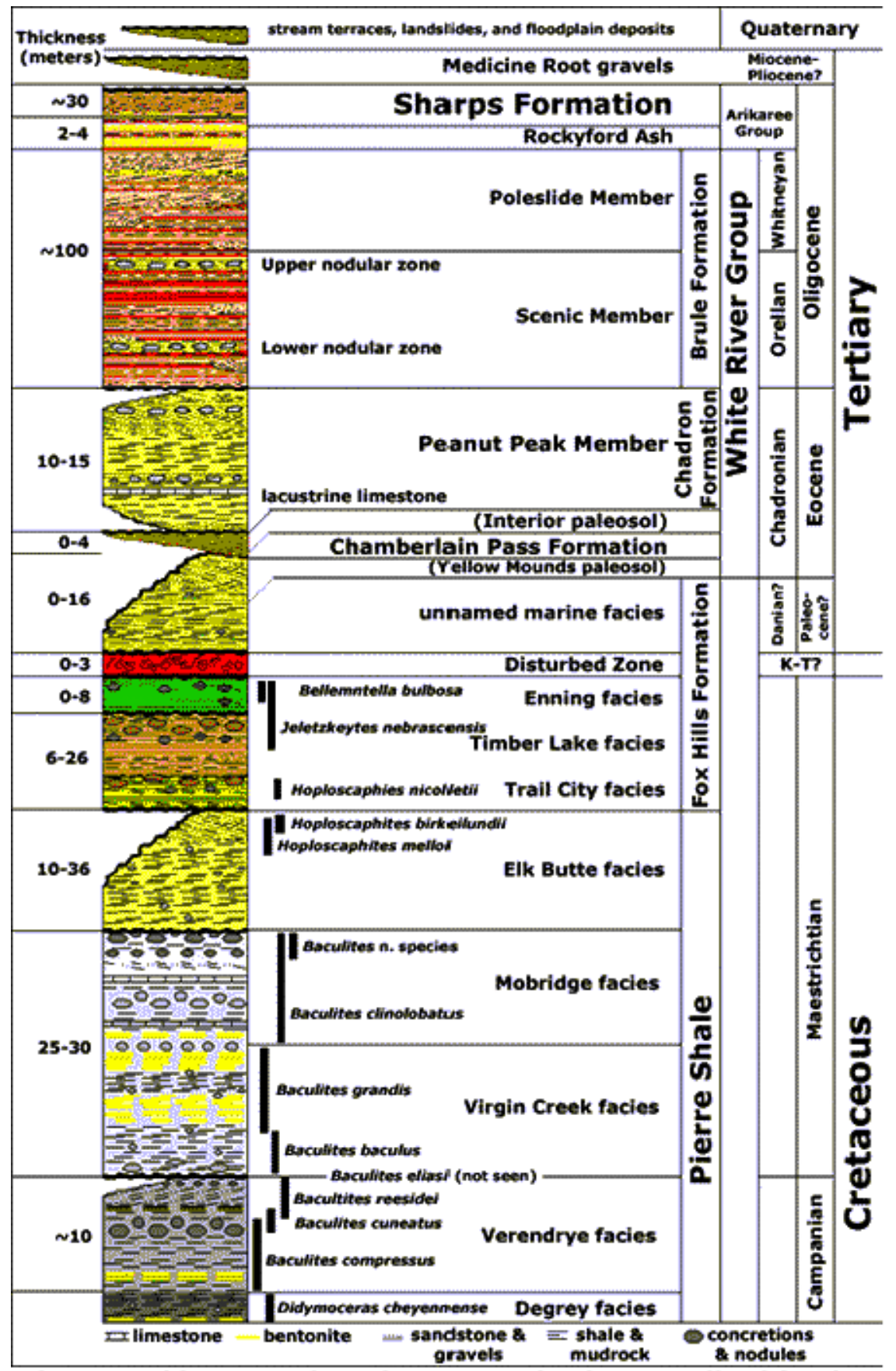

Figure 8. This composite columnar section is generalized for the North Unit of Badlands National Park. Note that the composition and thickness of rock units vary considerable from location to location, and are not drawn here to perfect scale. Named "facies" of the Pierre Shale and Fox Hills Formation follow the Type area for these formations in north central South Dakota (revision of Stoffer, et al, 1998). White River nomenclature is after D.O. Terry, 1998. 
Some fault offset that might be associated with the SCAFS is probably related to more recent deep-seated slumping along the escarpments. However, Tertiary and older movement histories can be established where faults and folds display evidence of truncation by erosion (forming angular unconformities) or contemporaneous movement during deposition. Figs. 9 to 13 illustrate structures in Badlands' North Unit.

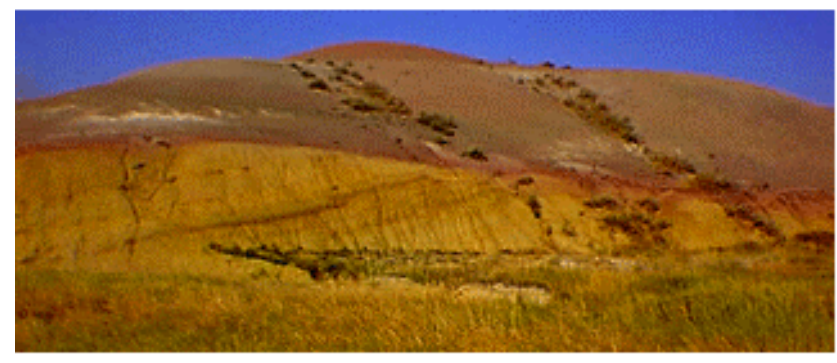

Figure 9. A cut bank along upper Conata Creek reveals an angular unconformity between the dipping Fox Hills (Yellow Mounds) and the overlying gray mudrock of the Chadron. A thin red layer (Interior paleosol) pinches out across the top of the folded and erosionally truncated underlying beds. This angular unconformity suggests that the formation of the Sage Creek Arch was already in progress of development before late Eocene time.

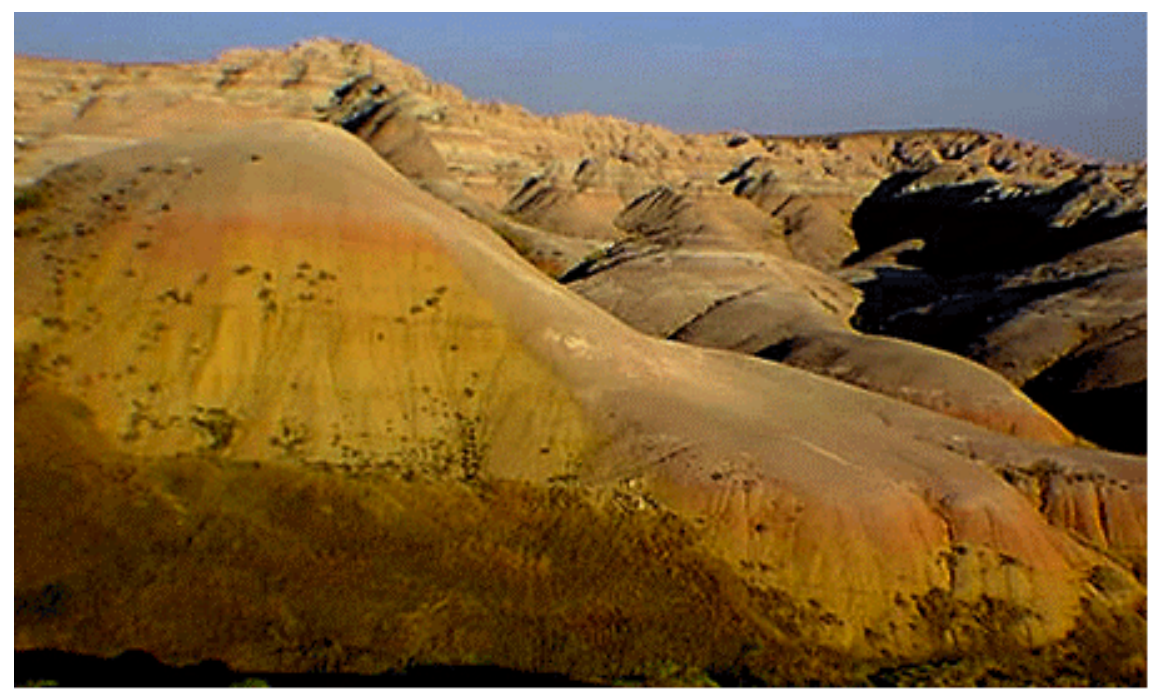

Figure 10. A normal fault with about 10 meters of displacement puts Fox Hills (Yellow Mounds paleosol) adjacent to Chadron Formation. Higher in the cliff face offset in the Scenic Member of the Brule is apparent along the same fault. The Scenic Member thins across the Sage Creek anticline, and is also crosscut by this fault. This suggests that the Sage Creek anticlinelfault system was active during and following Oligocene time.

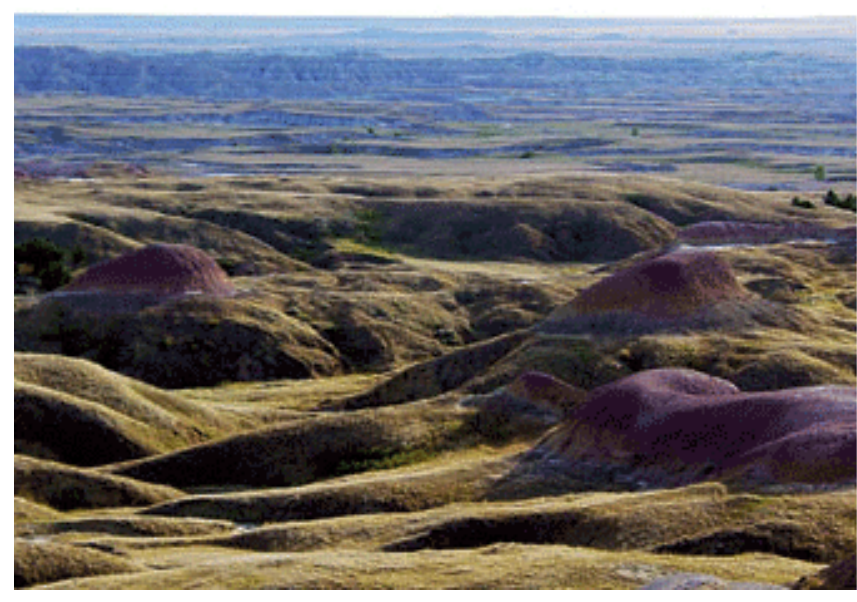

Figure 11. Small hills in the Yellow Mounds and Interior paleosols highlight the crest of the Sage Creek anticline in the Grassy Tables Overlook area. South of the anticline (as seen in the far distance in this image) is an area dominated by sod tables underlain by flat-lying strata of the White River Group. 


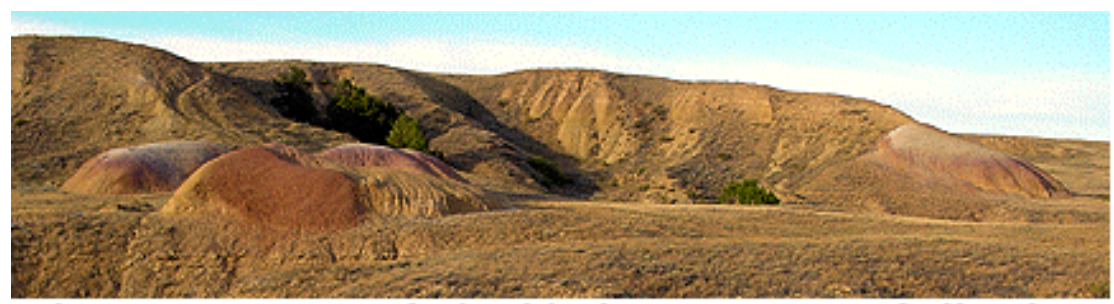

Figure 12. A reverse fault with about $\mathbf{2 0}$ meters of offset juxtaposes Chadron Formation (white) adjacent to strata of the Fox Hills Formation (yellow). This image was taken from the Wilderness Access Trail south of the Sage Rim Road (just west of the Roberts Prairie Dog Town in Section 3, T2S, R15E). This fault occurs along the southern flank of the Sage Creek Anticline.

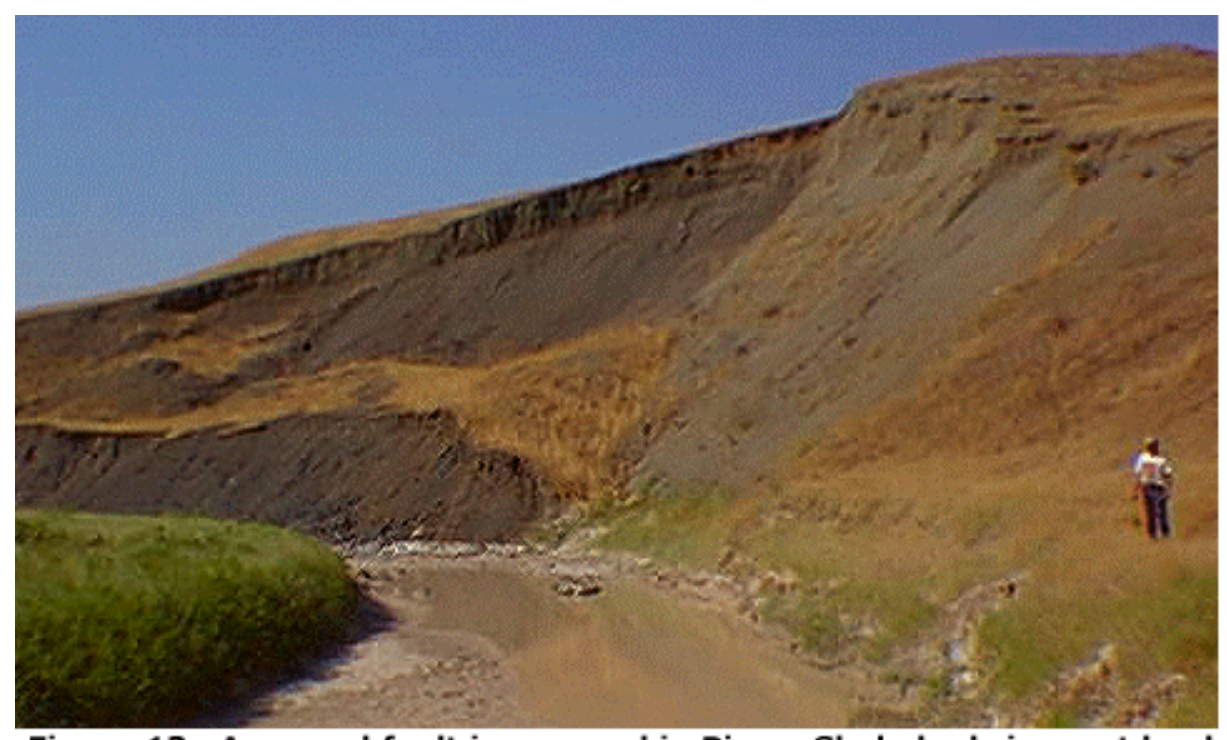

Figure 13. A normal fault is exposed in Pierre Shale beds in a cut bank along Sage Creek north of the Sage Rim Road Bridge. Light gray beds of the Mobridge facies (right) have dropped relative to the dark gray shale of the Verendrye facies (left). Total displacement along this fault is in the range of $\mathbf{5 0}$ meters. Whether this offset is a result of faulting related to the SCAFS or is a deep-seated slump is unclear. In the foreground is the remains of a smaller slump block that is gradually being eroded away Sage Creek. 


\section{Cretaceous Geology of Badlands National Park}

Sedimentary rocks of Late Cretaceous age are exposed along the lower stream drainages in several areas within Badlands National Park. Cretaceous-age sedimentary materials are exposed along the drainages of the Sage Creek watershed in the North Unit and throughout the Sage Creek Wilderness Area (fig. 14). Less extensive outcrop areas occur in the Conata Creek drainage area near Dillon Pass, and along Cedar Creek in the park's South Unit. The Cretaceous rocks are of marine origin whereas the overlying Tertiary White River beds are terrestrial deposits. The physical and geochemical differences between these rock groups have far-reaching impact on the modern environment in the park. Compared with the overlying sediments of the White River beds, the

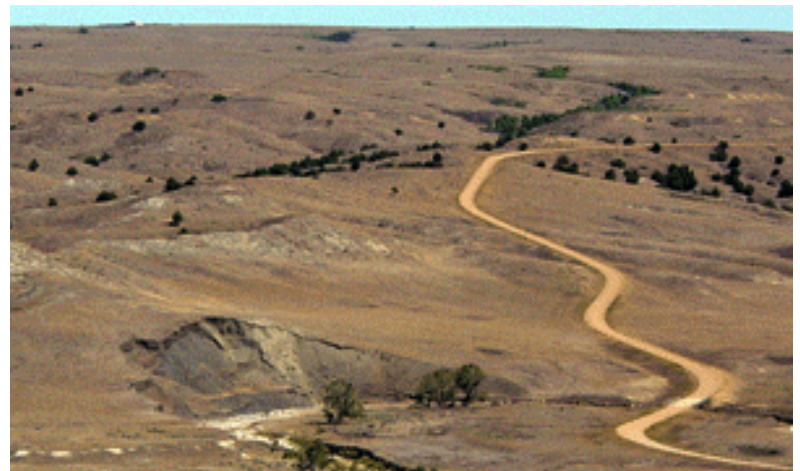

Figure 14. The Sage Rim Road crosses a landscape underlain by Late Cretaceous rock formations: the Pierre Shale (grays) and the Fox Hills (tan or buff colors. Sage Creek is in the foreground. marine Cretaceous rocks break down relatively slowly, yet produce soils that are both rich in nutrients and hold moisture. As a result, areas underlain by Cretaceous bedrock tend to be heavily exploited by plants well adapted to the high western prairie.

The Cretaceous section in Badlands National Park preserves a history of gradual changes in sea level in the Western Interior Seaway. It also preserves a record of evolution of marine species and environmental changes. Two named rock formations represent the Cretaceous stratigraphic sequence in the park: the Pierre Shale and the Fox Hills Formation. The oldest Cretaceous rocks exposed in the park consist of marine mudrocks deposited about 75 million years ago (during the later Campanian and Maestrichtian Epochs of the Cretaceous Period). Marine conditions remained in the Badlands region for an additional 10 million years. The Late Cretaceous was a time when geologic and environmental changes were occurring in the region and around the globe. The Laramide Orogeny began in this time period, and resulted in the gradual uplift of the Rocky Mountains. These mountain uplifts (and associated volcanism further to the west) poured vast quantities of sediment into the Western Interior Seaway basin. This created a broad coastal flood plain that progressively spread eastward, filling in around the rising uplifts as they developed (such as the Black Hills). West of the seaway, the coastal plain supported a subtropical coastal forest ecosystem (which included dinosaurs).

This pattern persisted until a great catastrophe in Earth's history occurred—at least one great asteroid struck in the vicinity of the Yucatan Peninsula. This asteroid impact (or impacts) occurred around 65.5 million years ago and caused global destruction, possibly assisting the extinction of a large percentage of animal and plant groups including dinosaurs on land, and in the marine world, the ammonites, most marine reptiles, and many other marine species. The story of this "mass extinction" is clearly preserved in the sedimentary rock sequence in Badlands National Park. The interval in geologic time and in the sedimentary rock record is referred to as the Cretaceous/Tertiary Boundary (K/T). Although most of the larger, more familiar life forms of the Cretaceous were gone, marine or marginally marine conditions persisted in portions of the Western Interior of the continent well into the following early portion of the Tertiary Period.

\section{Resolving Cretaceous Geologic History Through Paleontology}

Fossils and sedimentary features preserved in the mudrocks of the Pierre Shale reveal information about conditions in the Western Interior Seaway. At times the Badlands portion of the seaway had a diverse marine fauna that lived both in and on the seabed, or swimming above in the water column. When sea level was relatively shallow waves and currents caused mixing of the water, allowing oxygen-rich water to support a rich fauna at the seabed. With an abundant sea-bottom food supply the seaway could also support 
a large and diverse swimming fauna. Fossil beds that accumulated during these periods of low-standing sea level preserve a mix of shelled molluscs (mostly clams and ammonites), arthropods, and rare bones, teeth, and scales of fish and swimming reptiles. In addition, traces of burrows and tracks of bottom fauna are preserved, demonstrating that many other invertebrates lived in the seabed, but their soft-body parts have not been preserved (or found). Most of the shell material in these intervals is fragmented or disarticulated by bioturbation; some are preserved in concretions (fig. 15).

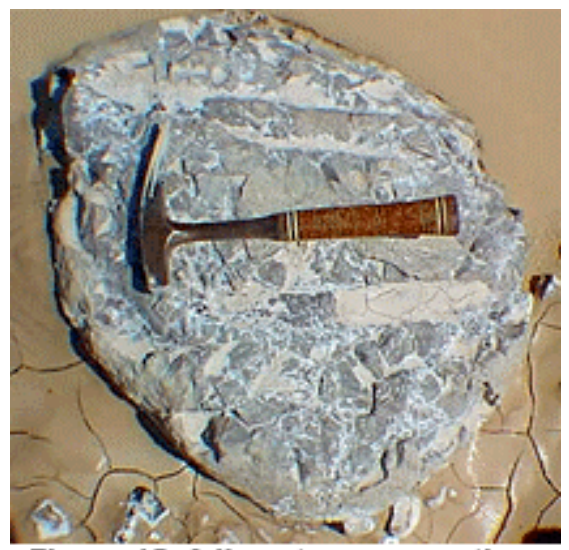

Figure 15. A limestone concretion from the Pierre Shale contains marine invertebrate fossils.

At other times, the seaway was either deeper or stagnant, and was essentially inhospitable except for organisms adapted to hypoxic (oxygen-depleted) conditions, or for swimming organisms that could survive in a thin zone of habitable oxygenated water near the surface. In these hypoxic intervals, the shells of ammonites are relatively scarce, but where they occur they tend to be more complete. In some beds, shell beds provide evidence that massive die-offs occurred. Perhaps storms or upwelling events mixed the water column, robbing available oxygen and suffocating most of the organisms.

Through time, different species migrated into the seaway basin, either coming up from the Gulf of Mexico or coming in from the north from the Arctic region. The new arrivals either eventually disappeared or adapted and became endemic to the seaway. The ammonites in the Pierre Shale and Fox Hills Formation provide excellent documentation of evolution, competition, and

environmental change through time. The identifiable differences in ammonite shell morphology through time, particularly with baculites, provide a basis for mapping and correlating belts of sedimentary rock where the different species are preserved. Mapping sedimentary rock units by the fossils is the science of biostratigraphy. A biozone interval is a sequence of sedimentary strata where a particular species first appears (at the base), flourishes, and then vanishes (at the top). Some species last a long time and change very slowly, whereas other appear and disappear quickly. It is the ones that were short-lived-yet abundant while they lasted - that are most useful for biozone mapping. In the Western Interior region, the ammonites have proven to be the most useful for mapping.

\section{Cretaceous Stratigraphy of Badlands National Park}

The Pierre Shale and Fox Hills Formation are subdivided into more discrete intervals based on fossil range zones (biostratigraphy) or by physical rock characteristics (lithostratigraphy). All fossils used in this biozonation (listed below in italics on fig. 16) are species of swimming molluscs, mostly ammonites. The lithologic names (facies) follow the naming scheme for equivalent named stratigraphic members in the Missouri River valley (with exception of the Enning facies, Disturbed Zone, an Unnamed marine facies of the upper Fox Hills Formation which do not have equivalent units recognized in the Missouri Valley region).

Late Cretaceous molluscs used for biozonation in the park follow the chronology Gill and Cobban (1966) and with modification after Landman and Waage (1993) and Stoffer et al., (1998). The biozonation presented in this report is based only on fossils recovered in the park or within close proximity on the Buffalo Gap National Grasslands adjacent to the park (additional biozones are recognized in other areas). Although many other organisms (both invertebrate and vertebrate) could supplement this biozonation, only species presented here are considered common or significant for correlation purposes. In the future, additional biostratigraphic definitions will no doubt become available. Ammonites are perhaps the best means for correlation because they are relatively common and relatively easy to recognize in the field, and they vary considerably in form through the stratigraphic section allows this separation into unique species at different levels in the section. 


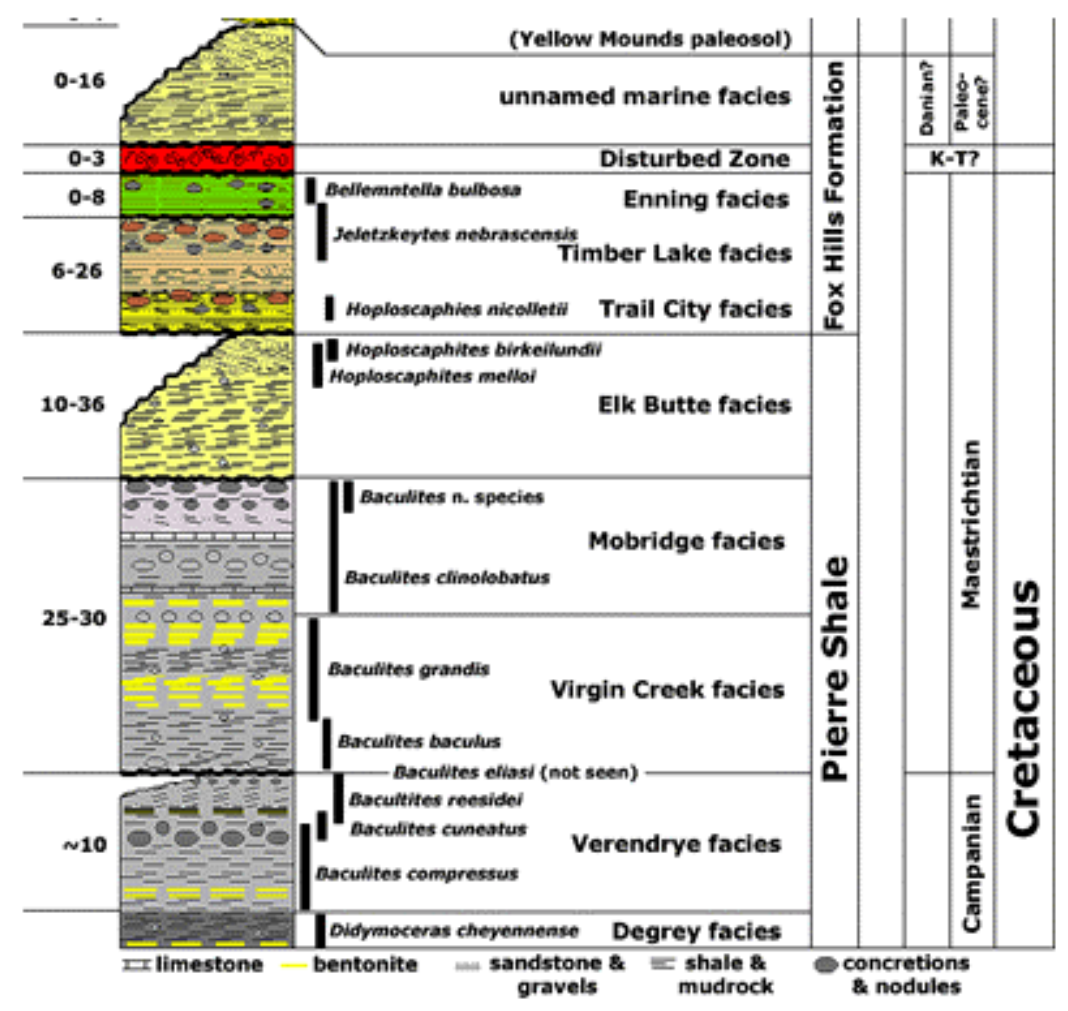

Figure 16. Cretaceous stratigraphy of Badlands National Park (North Unit).

All specimens illustrated presented below were found in the vicinity of Badlands National Park (including the Buffalo Gap National Grasslands and private lands surrounding the park). Representative fossil specimens from within Badlands National Park were collected under provisions of a NPS collecting permit. All specimens present here are in the repository collections of the Department of Invertebrates of the American Museum of Natural History in New York City or are currently on display at the USGS in Menlo Park California.

\section{Pierre Shale}

Only the upper portion of the Pierre Shale is exposed within Badlands National Park. The age of strata in the park spans the Late Cretaceous period from the Late Campanian (about 74 million years) through the Early Maestrichtian (about 69 million years). In the northern portions of the park region, the Fox Hills Formation (Early to Late Maestrichtian) overlies the Pierre Shale. In the Missouri Valley region the Pierre Shale is subdivided into members including from oldest to youngest: DeGrey Member, Verendrye Member, Virgin Creek Member, Mobridge Member, and Elk Butte Member. Member subdivisions for the Pierre Shale have not been recognized north and west of the Black Hills; subdivisions of the Pierre Shale have not been previously established for Badlands National Park. However, the term "facies" is used here to designate similar stratigraphic subdivisions that are recognizable in the park that share similarities with the formally named members in the Pierre Shale in the Missouri River valley region. Descriptions of each of the member "facies" and corresponding ammonite range fossil zones are described below. 


\section{History of Pierre Shale Nomenclature}

The stratigraphic nomenclature of the Pierre Shale has changed over time. Meek and Hayden (1854) originally assigned the name "Formation no. 4 of the Cretaceous" while mapping the Nebraska Territory (which then included the Dakotas, Wyoming, and Montana). They later established the name "Fort Pierre group" (Meek and Hayden, 1861). Their early reports established that the "Fort Pierre" shale includes all strata between the gray marl of the Niobrara Formation (exposed along the Missouri River near the South Dakota-Nebraska border) and the overlying Fox Hills Formation (found in the highest hilltops along the Missouri River valley in the north central South Dakota region). Meek and Hayden (1861) extended the name "Pierre" across the region to include the Badlands National Park region (where they investigated the shale exposures along Sage Creek area while exploring the White River badlands; see fig. 17). Fort Pierre was along the Missouri River in what is now Pierre, the state capital of South Dakota. Darton (1896) shortened the name to "Pierre Shale".

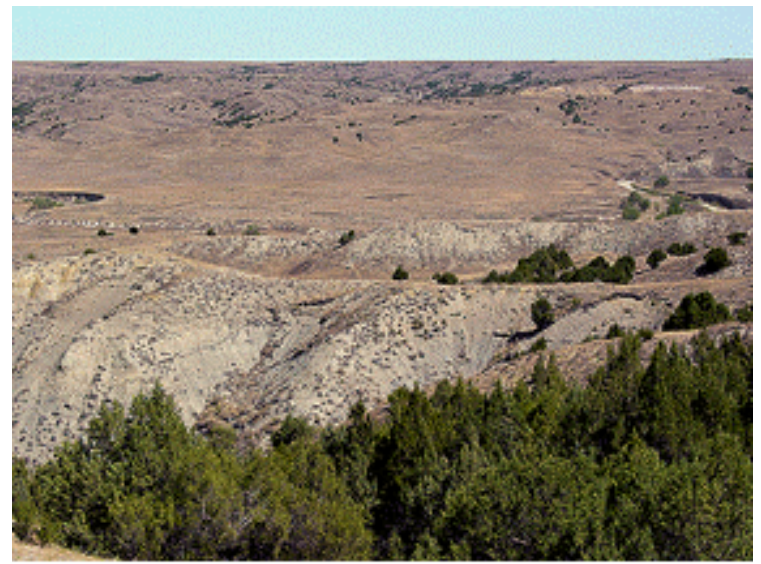

Figure 17. Pierre Shale exposures along Sage Creek were first studied in a scientific context by the Meek and Hayden Survey (1861).
Searight (1937) established member subdivisions for identifiable lithologies within the Pierre Shale along the Missouri River valley in South Dakota. Since Searight's original report there have been many recommended revisions to the stratigraphic nomenclature for the Pierre Shale, but most apply only to the lower portion of the Pierre (below the DeGrey Member) [Agnew and Tychsen, 1965]. The name, Monument Hill Member, was applied to the upper portion of the Pierre Shale (DeGrey Memberequivalent and higher) around the northern and western flanks of the Black Hills by Rubey (1930), but this member name was later abandoned by Gill and Cobban, 1966 (who included equivalent strata into portions of the Lower and Upper unnamed shale members of the Pierre Shale in that region). Crandall (1958) redefined and clarified definitions for the named members of the Pierre Shale along the Missouri River valley and provided additional paleontologic and lithologic detail to stratigraphic units. However, Gill and Cobban (1966) established a reliable ammonite-based biozonation scheme for the Pierre Shale that is recognized as an effective means of correlation across the region.

Although the name, Pierre Shale, was established for South Dakota, the name has been loosely applied across the entire Western Interior region today (ranging from Texas to Alberta). The name is also formally established for equivalent-age strata in the north in North Dakota, east of the Colorado Rockies, and in the Powder River Basin region of Wyoming. In Montana equivalent latest Campanian- and Maestrichtian-age strata are called the Bearpaw Shale.

\section{DeGrey Facies}

Only the highest portion of the DeGrey Member (facies) may be exposed in the lower Cedar Creek drainage along the western side of the Badlands' South Unit. Although this unit is not completely exposed in the park, fossil material from this member has been found in lag deposits higher in the stratigraphic section. In the park vicinity, this unit crops out along the Cheyenne River Valley and along Indian Creek west of Scenic. In outcrop, the DeGrey facies is typically dark, reddish-gray, fissile shale with thin yellow bentonite (jarosite) beds. It contains red-weathering siderite concretions that are typically barren or contain inoceramid clams. Most other fossils are scarce. Diagnostic fossils the DeGrey Member include the strangely coiled ammonite, Didymoceras cheyennense (fig. 18) and the fragile, straight-shelled ammonite, Baculites corregatus (fig. 19). In the park region, the large clam Inoceramus sagensis occurs in the DeGrey facies and in even greater abundance in the overlying Verendrye facies. 
The thickness of the DeGrey facies is undetermined in that the lower boundary of the member with not been determined within the Badlands region. However, it probably is similar in thickness to exposures along the Missouri River (where it is approximately 30 meters thick in the vicinity of Pierre, South Dakota). Accessible exposures to DeGrey facies are located along Highway 44 northwest of Scenic along the hillsides of Rapid Creek in section 12, T2S, R12E.

Crandall (1950) established the name DeGrey Member for units earlier assigned to the "Agency-Oacoma bed" of Gries (1942). Crandall established a Type area for the DeGrey Member in a cut bank along the Missouri River southeast of the settlement of DeGrey in Hughes County, South Dakota. The noncalcareous, bentonitic shale beds of the DeGrey Member overlie the calcareous marl of the Crow Creek Member. The Crow Creek Member has not been identified in the Badlands region.

\section{Didymoceras cheyennense (Meek and Hayden, 1856)}

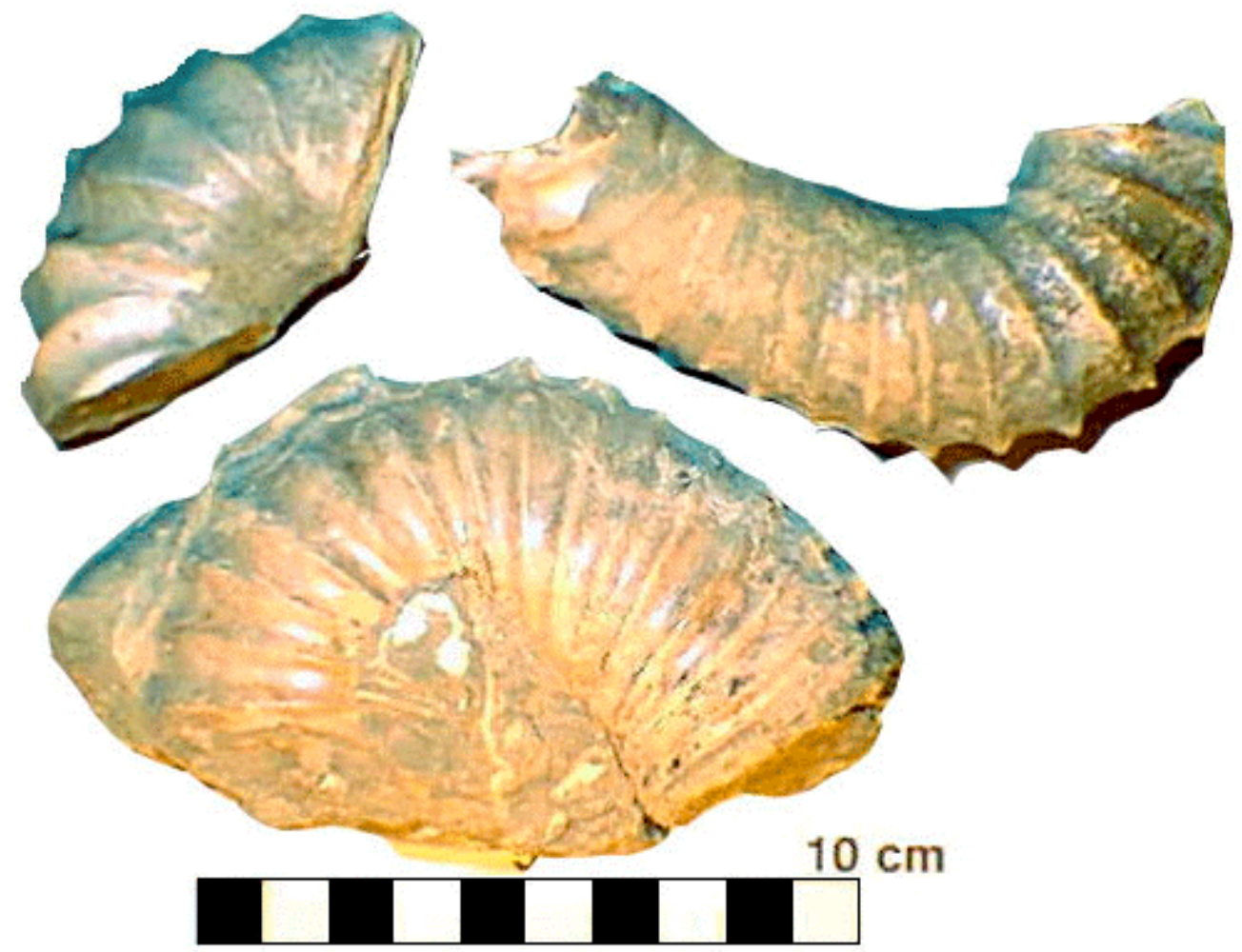

Figure 18. Didymoceras cheyennense (Meek and Hayden, 1856) is a biozone range fossil of the DeGrey Member of the Pierre Shale. The DeGrey Member is not exposed in the park, but it crops out in the region along the Cheyenne River Valley and around the east flank of the Black Hills. The upper two specimens are from Highway $\mathbf{4 4}$ cuts along the Cheyenne River. Reworked specimens in concretions have been found in lag deposits higher in the Badlands section (for instance, the lower specimen shown above came from a lag of concretion material as along the Campanian-Maestrichtian stage boundary unconformity exposed along Cedar Creek in the South Unit region). These are only partial specimens of the ammonite body chambers. 


\section{Baculites corrugatus (Elias, 1933)}
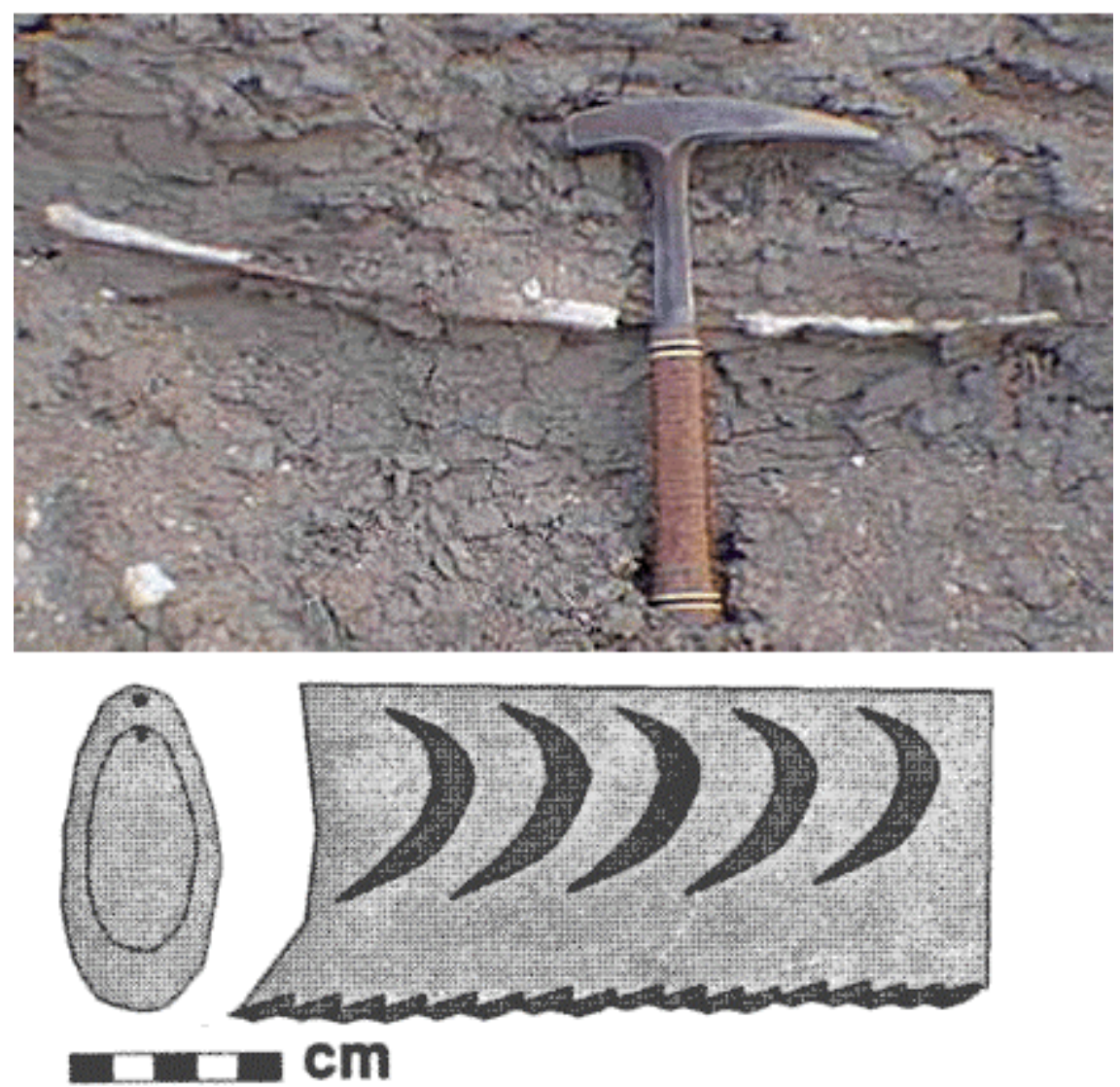

Figure 19. Baculites corrugatus is a biozone range fossil of the DeGrey Member of the Pierre Shale. Although not found in the park it has been recognized in outcrops along tributaries of the Cheyenne River in the Buffalo Gap National Grasslands adjacent to the park. The specimen shown above was weathering from a cut bank along Indian Creek (west of Scenic, South Dakota). Characteristic cross-sectional (juvenile and adult) and flank profiles are useful for identifying the species.

\section{Verendrye Facies}

V.F. Searight (1937) established the Verendrye Member as a gray shale interval with abundant limestone concretions between what is now the DeGrey Member (below) and the overlying bentonitic shale beds of the Virgin Creek Member. The Type area for the Verendrye Member is beneath the Verendrye Monument at Fort Pierre, Stanley County, South Dakota. The Verendrye Member can also be defined by biozonation, particularly by three ammonite species: Baculites compressus, Baculites cuneatus, and Baculites reesidei (figs. 22 to 24). However, the Verendrye is also recognizable by a common species of giant clam, Inoceramus sagensis that occur in large gray concretions (fig. 25). The Meek and Hayden Survey of the late 1850's observed these fossils in the area and named the fossil after Sage Creek.

In the North Unit, the Verendrye is exposed only along Sage Creek from the vicinity of the campground northward to the park boundary here it reaches its maximum thickness of about 15 meters in the vicinity of the Sage Creek bridge near the campground. 
The Verendrye facies is also partially exposed along Cedar Creek in the South Unit. The member consists of medium-to-dark gray, fissile shale and bears an abundance of limestone concretions that range up to about a meter in diameter (figs. 20 and 21). Most concretions are septarian and are barren of fossils, but many display fossil hash or preserve the mostly broken shells of a variety of marine invertebrates and an abundance of bioturbation structures. Within the park, the top of the member contains the greatest abundance of concretions, most of which display heavy septarian-fractures.

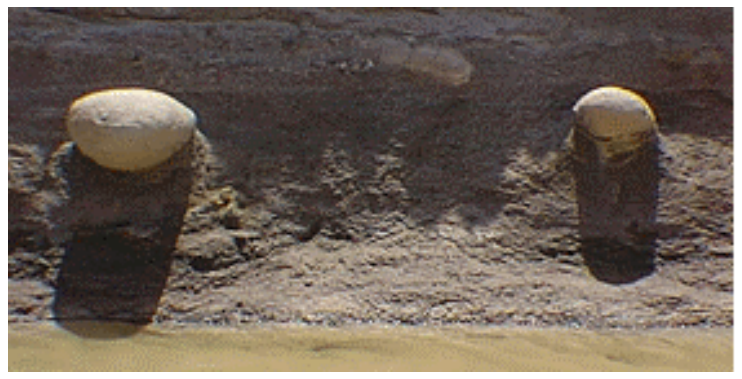

Figure 20. Limestone concretions stick out from eroding shale of the Verendrye facies exposed along Sage Creek. Concretions are typically barren inside, but the surfaces preserve a variety of bioturbation features from marine invertebrates. Bioturbation data can provide information about water depth and oxygen availability on the seabed.

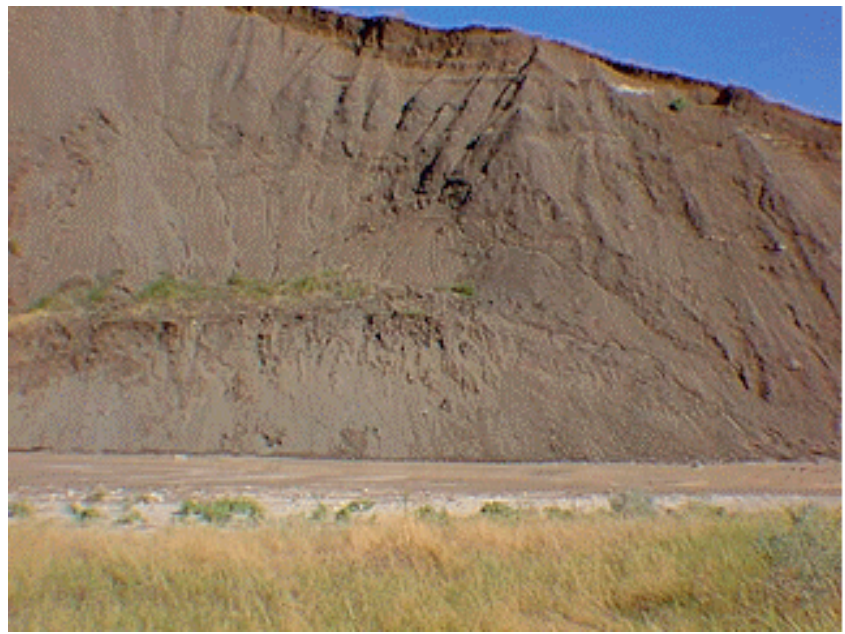

Figure 21. The Verendrye facies is exposed in a large cut bank along Cedar Creek in the park's South Unit. 
Baculites Compressus (Say, 1820)
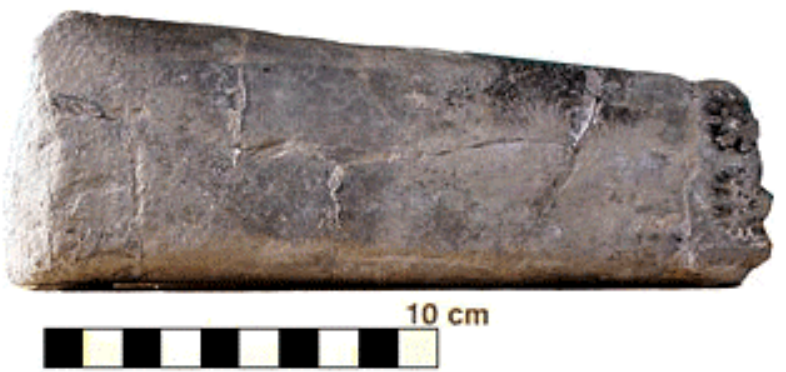

Figure 22. Baculites compressus is a biozone range fossil of the Verendrye Member of the Pierre Shale. It occurs in Verendrye facies throughout the park and region. Adult specimens display little flank ribbing and a more tapered flank profile relative to other baculite species. This specimen is from Verendrye facies exposed along Sage Creek.

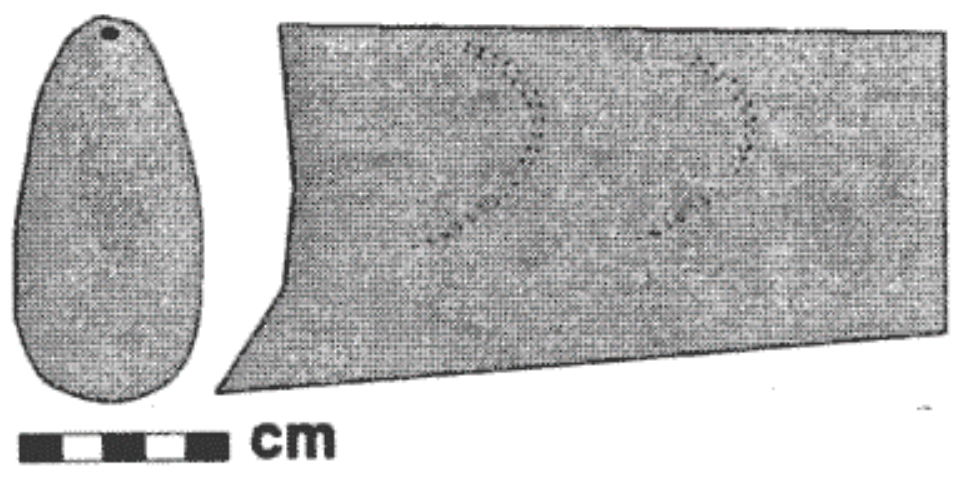

\section{Baculites cuneatus (Cobban, 1962)}
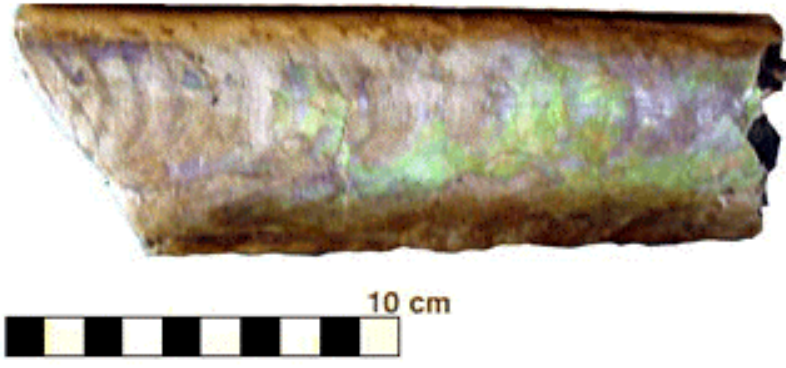

Figure 23. Baculites cuneatus is a biozone range fossil of the Verendrye Member of the Pierre Shale. It occurs in Verendrye facies throughout the park and region (this specimen came from along Cedar Creek near Redshirt, South Dakota). The species is recognizable by its closely spaced, low profile flank and ventral ribbing.

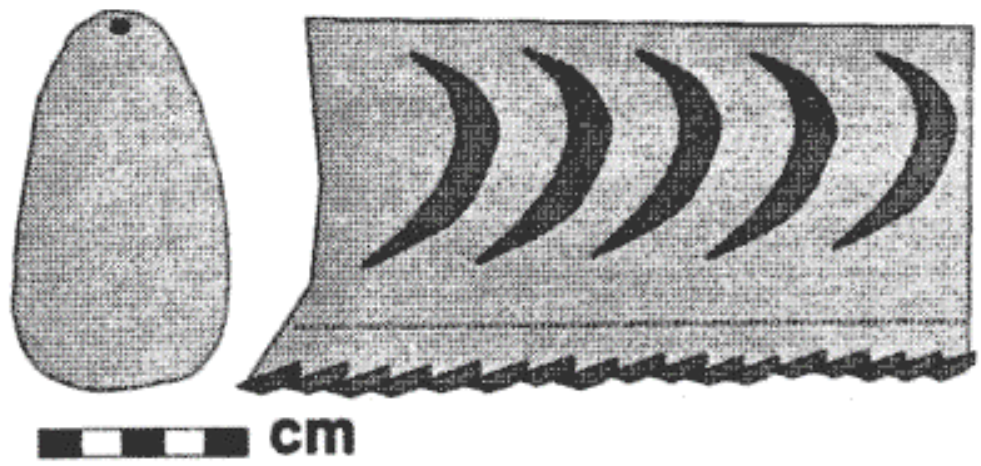


Baculites reesidei (Elias, 1933)

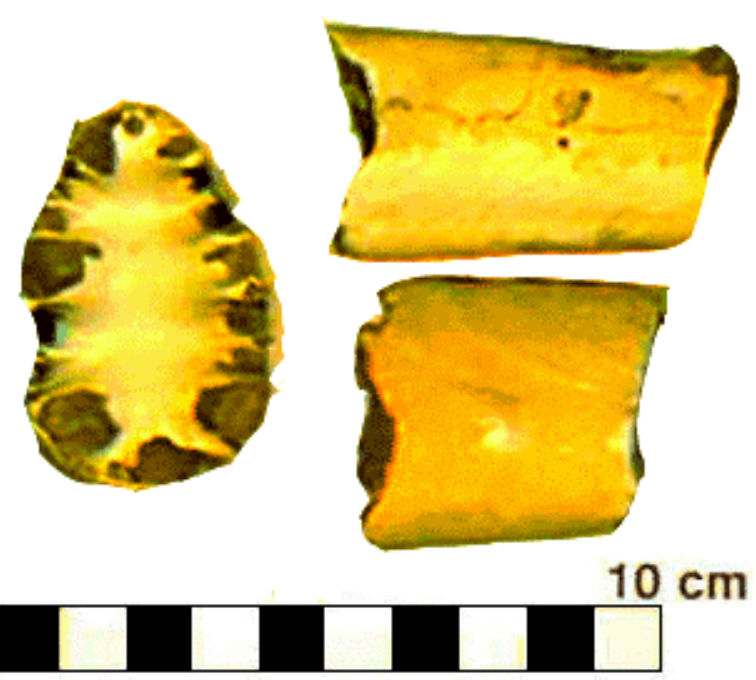

Figure 24. Baculites reeside $i$ is a range fossil of the upper Verendrye Member of the Pierre Shale. It occurs in Verendrye facies throughout the park and region. These specimens came from the upper Verendrye facies exposed along Cedar Creek near Redshirt, South Dakota. The species is recognizable by its more triangular cross sectional profile and by subtle linear channels along their lower (ventral) flanks.

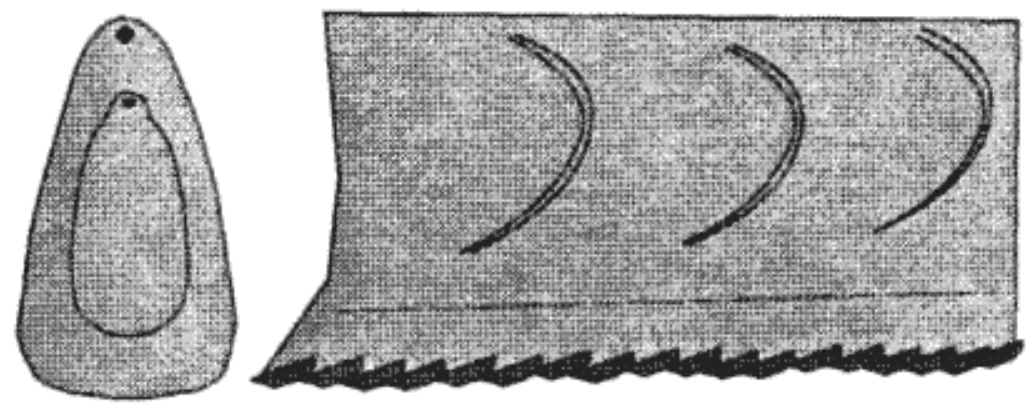

arn cm 
Inoceramus sagensis (Owen, 1852)
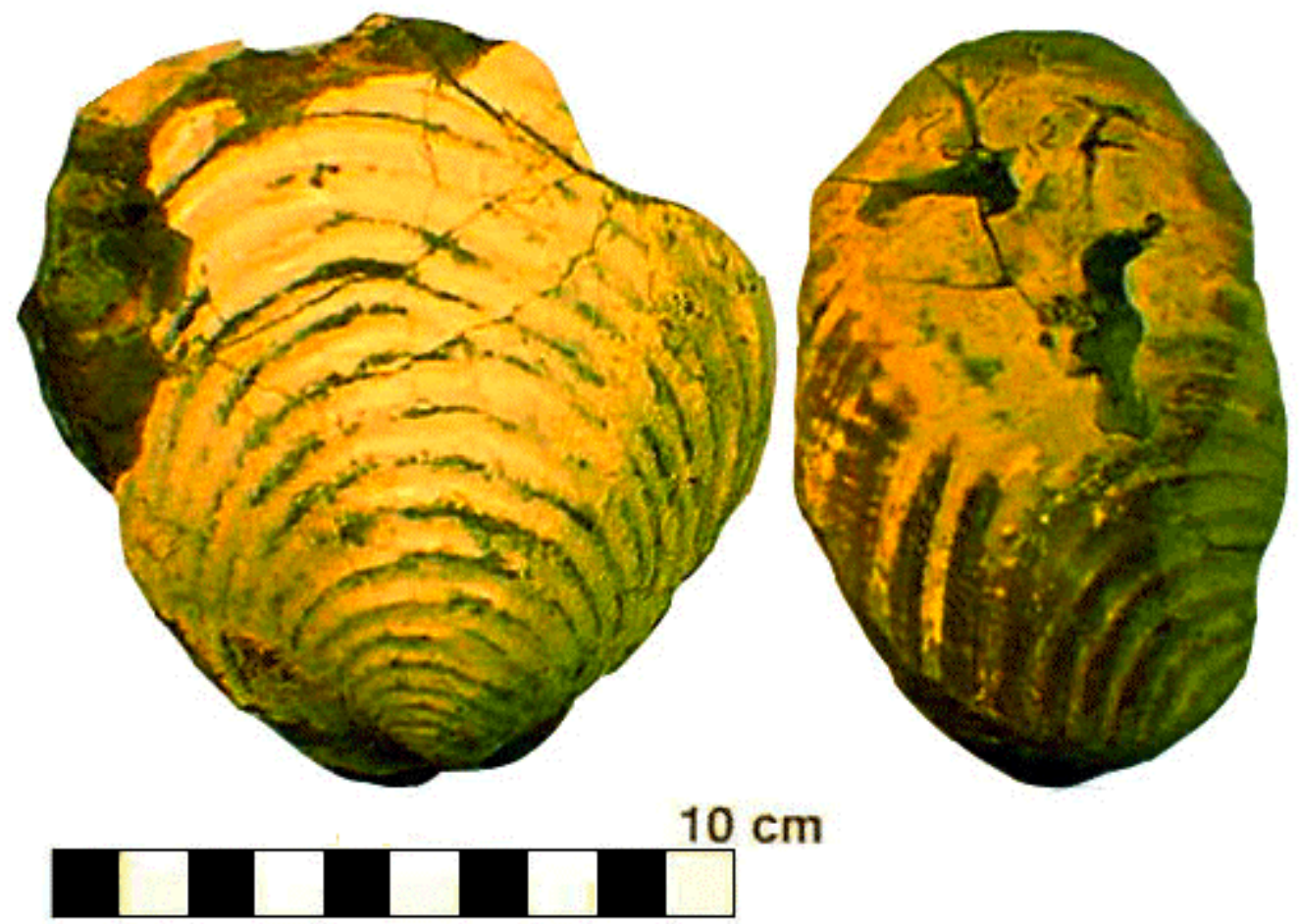

Figure 25. Inoceramus sagensis is perhaps the most common fossil in the upper Pierre Shale (late Campanian). It occurs throughout the DeGrey and Verendrye facies in the park and region. These specimens are from along Indian Creek (west of Scenic, South Dakota.

\section{The Campanian-Maestrichtian Boundary Unconformity}

An unconformable surface locally defines a boundary between the Verendrye facies and the overlying Virgin Creek facies in the park region. This unconformity is recognizable by a sharp change in lithology (the underlying Verendrye is much darker) and in some exposures by the preservation of a weathered soil horizon (illustrated below with an exposure along South Fork of Sage Creek, about a mile south of the Sage Creek Campground; fig. 26). Elsewhere shell and rock lag deposits bearing reworked materials (including fossils and concretions) occur along this unconformity. Based on correlation to similar stratigraphic section in the region, throughout the United States, and around the world, this unconformable surface represents the Campanian-Maestrichtian stage boundary (between the last two epochs of the Late Cretaceous). The origin is an inferred fall and rise in global sea level. Many species that existed in the Campanian strata are not found above the boundary, which suggests that significant ecological changes occurred during this transitional period roughly between 72 and 71 million years ago (Stoffer, 1998). 


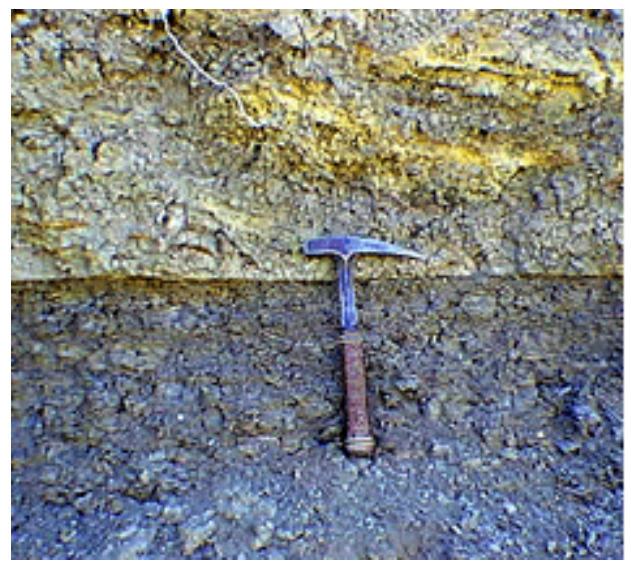

Figure 26. The Campanian-Maestrichtian stage boundary unconformity is exposed in cut banks along the South Fork of Sage Creek (this exposure is about one mile south of the Sage Creek Campground). The shale around the hammer handle has a slightly red appearance from having once been exposed to subaerial weathering before the marine sediments of the overlying Virgin Creek facies were deposited.

\section{Virgin Creek Facies}

V.F. Searight (1937) designated a section of shale bearing numerous thin, yellowish bentonite beds as the Virgin Creek Member (after a creek with that name located near the now abandoned community of Promise, Dewey County South Dakota. In the North Unit, this unit crops out throughout the middle hillside slopes throughout the Sage Creek Valley including the lower drainage basins of East Fork and Middle Fork, and most of South Fork. The lower part of the member displays an abundance of thin bentonite layers or intermittent stringers that occur interbedded within medium gray shale (fig. 27). The lower part of this member displays an abundance of limestone concretions that typically developed within or adjacent to bentonite beds. Within the base of the unit, some concretions preserve intraclasts (ripped up mud chips). Fossils are generally scarce within the lower bentonite-rich portion of the member. Specimens of the indicator fossil for the Virgin Creek Member, Baculites grandis, are not uncommon in the upper portion of the member. By comparison to the underlying Verendrye Member, the color of the shale is a lighter gray to a greenish-brown or olive color. The Virgin Creek Member is about 20 meters thick north of the Sage Rim Road, but grows progressively thinner to about 10 meters along South Fork.

Two older ammonites occur in the lower Virgin Creek facies (Baculites eliasi [fig. 28] and Baculites baculus [fig. 29]), but neither of these species is common in Badlands area, and the Baculites eliasi Zone may be entirely missing due to the unconformity at the base of the member. The abundance of bentonite beds and the widespread occurrence of a common ammonite, Baculites grandis (fig. 30), make the Virgin Creek Member easy to recognize throughout the region.

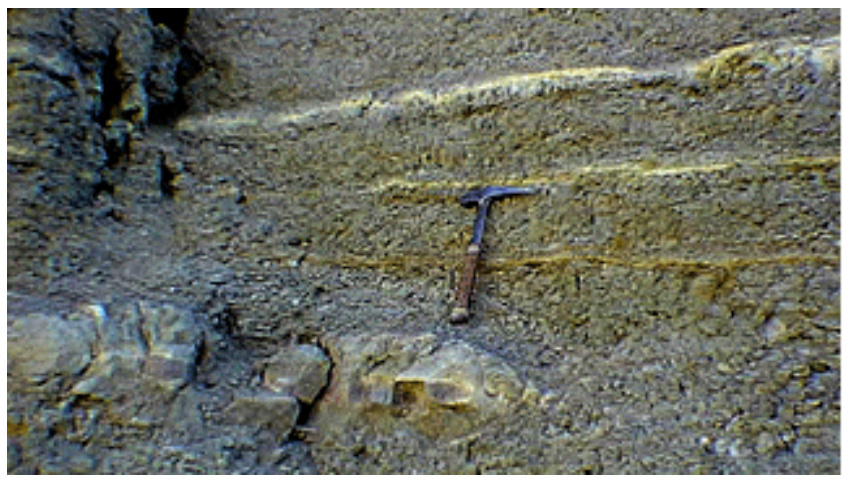

Figure 27. The lower portion of the Virgin Creek facies of the Pierre Shale is exposed in a cut bank along South Fork of Sage Creek near the campground. This exposure displays thin bentonite layers (yellow bands) above a barren limestone concretion (below the hammer). Fossils are not common in the Verendrye facies. 


\section{Baculites eliasi (Cobban, 1958)}

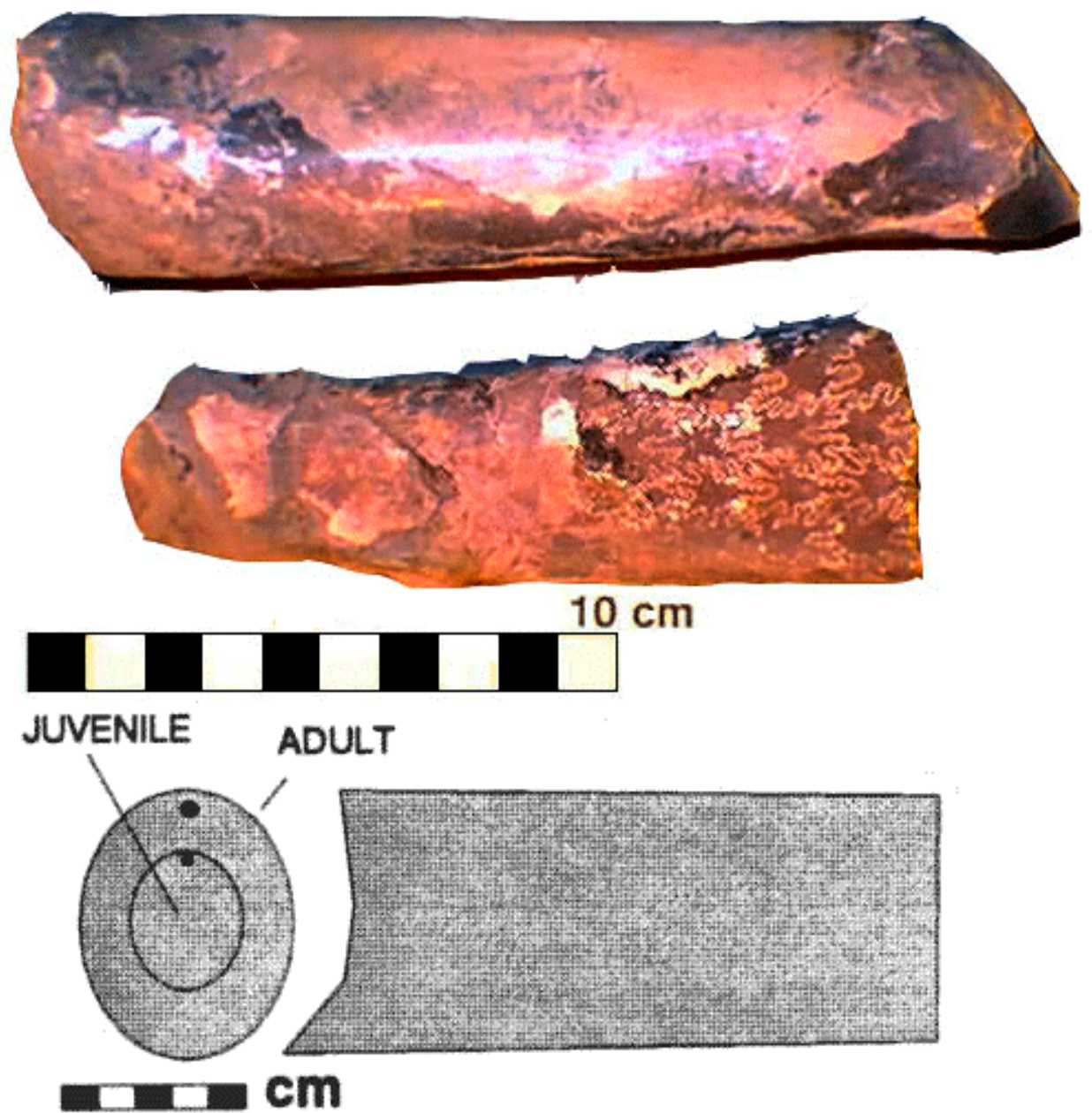

Fig 28. Baculites eliasi is a range fossil of the lowermost Upper unnamed shale member of the Pierre Shale in Wyoming. The species is recognizable by it more rounded crosssection profile and lack of flank or ventral ribbing relative to other baculite species. Baculites eliasi has not been found in the park, but occurs in outcrops along the Cheyenne River north of Wall, South Dakota. The range for this fossil corresponds with the Campanian-Maestrichtian stage boundary interval, and may not have been preserved in the park because strata that would otherwise bear this species is missing along an unconformity between the Verendrye and Virgin Creek facies. If the species occurs in the park, it would likely be found in the lowermost Virgin Creek facies. 


\section{Baculites baculus (Meek and Hayden, 1861)}

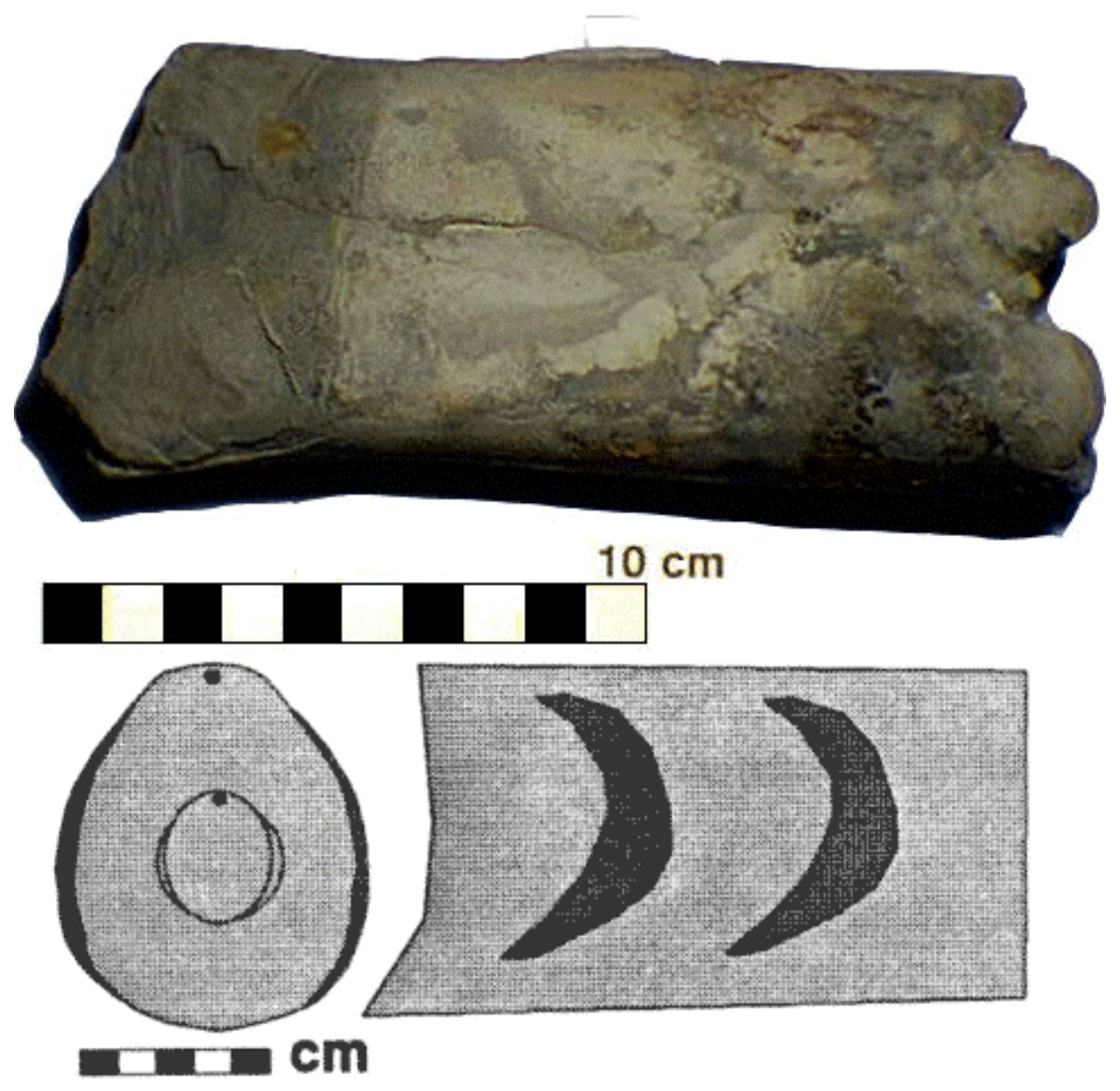

Figure 29. Baculites baculus is a range fossil of the mid to lower portion of the Virgin Creek Member of the Pierre Shale. The species is similar to its younger relative (Baculites grandis) but has a more rounded cross sectional profile and does not display as intense flank ribbing. Virgin Creek facies occurs throughout the park and region. This specimen was found in upper Virgin Creek facies along the South Fork of Sage Creek. 


\section{Baculites grandis (Meek and Hayden, 1854)}
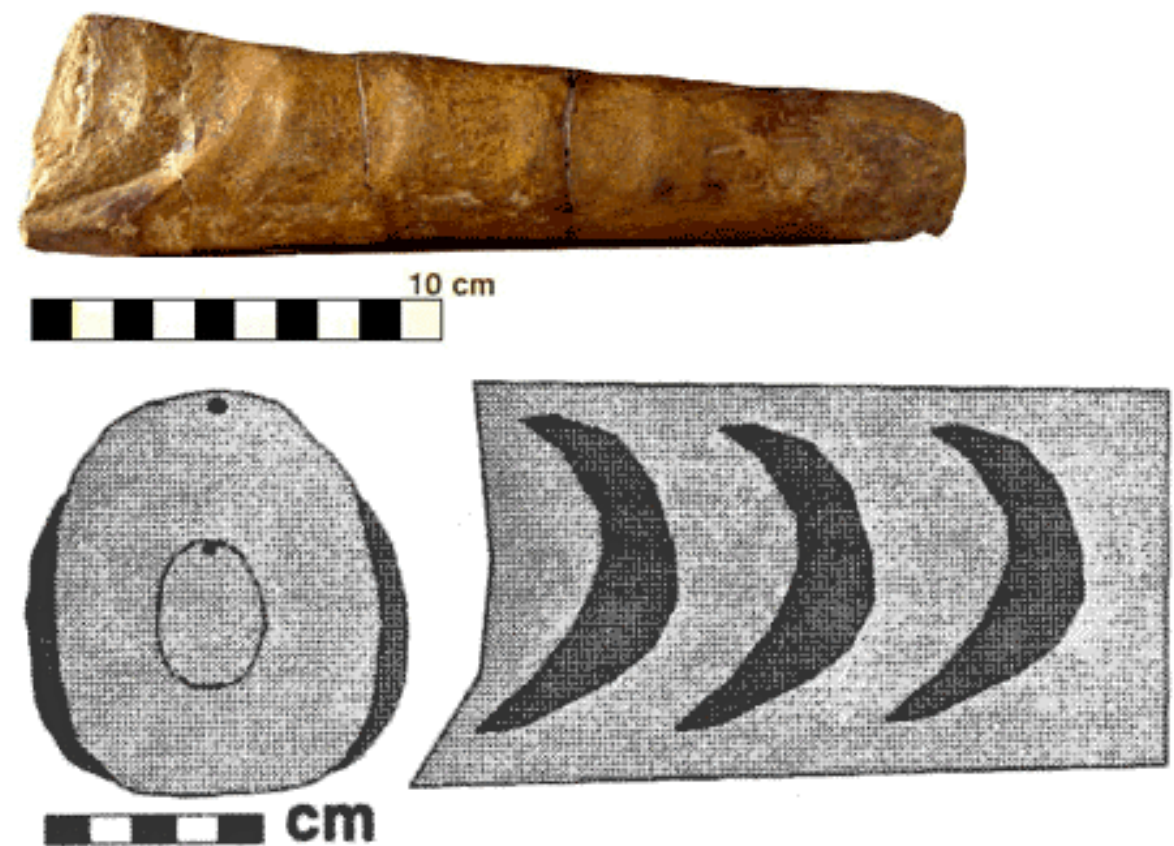

Figure 30. Baculites grandis is a range fossil of the upper Virgin Creek and lower Mobridge Members of the Pierre Shale. This fossil occurs throughout the park and region and is relatively abundant compared with other species. The species is recognizable by is strong flank ribbing, more oval cross sectional profile, and relatively large size of adult specimens. This specimen is from a road cut along Highway 41 about 15 miles south of Redshirt, South Dakota.

\section{Mobridge Facies}

W.V. Searight (1937) applied the name Mobridge Member to a 25 to 50 meter thick interval of calcareous shale, chalk, and marl in the upper Pierre Shale distributed along the upper hillsides all along the Missouri River Valley in South Dakota. A Type locality was established adjacent to the historic (now missing) Missouri River highway bridge at the town of Mobridge, South Dakota.

Intermittent layers of concretionary limestone define the occurrence of the Mobridge facies in the park region (fig. 31). In addition, the large, straight-shelled ammonite, Baculites clinolobatus, is relatively abundant in the Mobridge facies everywhere it occurs (fig. 32). The Mobridge facies is highly calcareous relative to the overlying siliceous shale of the Elk Butte facies.

The Mobridge facies is best exposed along the upper hillsides along the South Fork and Middle Fork valleys in the Sage Creek Wilderness Area in Badlands' North Unit. The higher calcareous content of the Mobridge facies makes it more resistant to erosion than the underlying and overlying strata. In unweathered exposures, the unit is a light bluish-gray color. It appears to have a gradational contact with the underlying Virgin Creek facies. In the best exposures along the South Fork of Sage Creek, the Mobridge Member is only about 5 meters thick. It grows progressively thicker to the north except in the vicinity of the Sage Creek Anticline where it is thin or missing, poorly exposed, or is heavily weathered beyond recognition. Near Wasta, South Dakota, the Mobridge interval—defined by its indicator species, Baculites clinolobatus - approaches 15 meters in thickness. The upper Mobridge facies displays an abundance of large limestone concretions that in some locations merge to form continuous micritic limestone ledges. The contact with the overlying strata is very poorly exposed except along South Fork where it appears unconformable beneath undifferentiated Fox Hills Formation. 


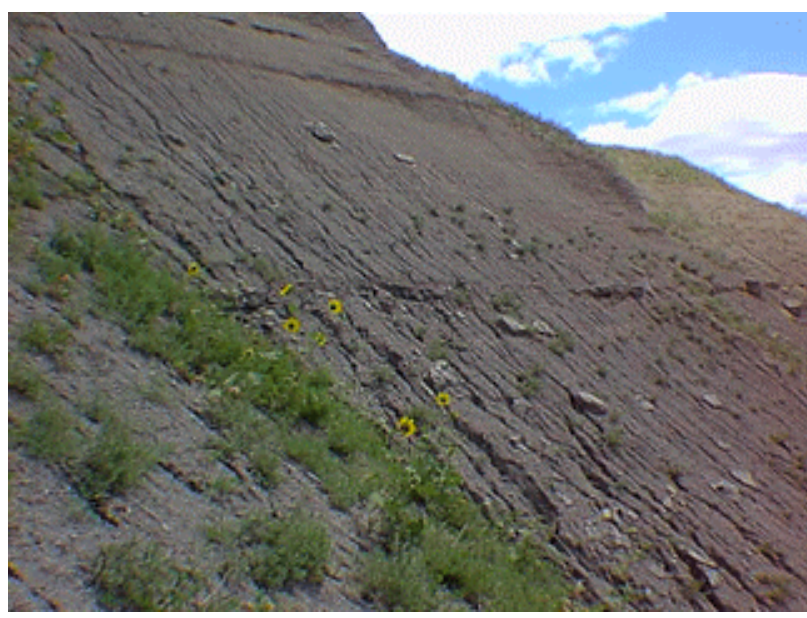

Figure 31. Limestone layers, marl, limestone concretions, and relatively abundant fossil shell remains are typical of the Mobridge facies throughout the Western Interior region. Warm seaway condition supported a "calcareous" marine fauna (both plankton and invertebrates). This exposure is along the Sage Creek near White Butte (about 2 miles east of the Sage Creek Campground). The Mobridge facies is limited to the calcareous beds that make up roughly the middle third of this image where concretionary ledges crop out. The upper portion in this image are Elk Butte facies, Virgin Creek facies are below.

\section{Baculites clinolobatus (Elias, 1933)}
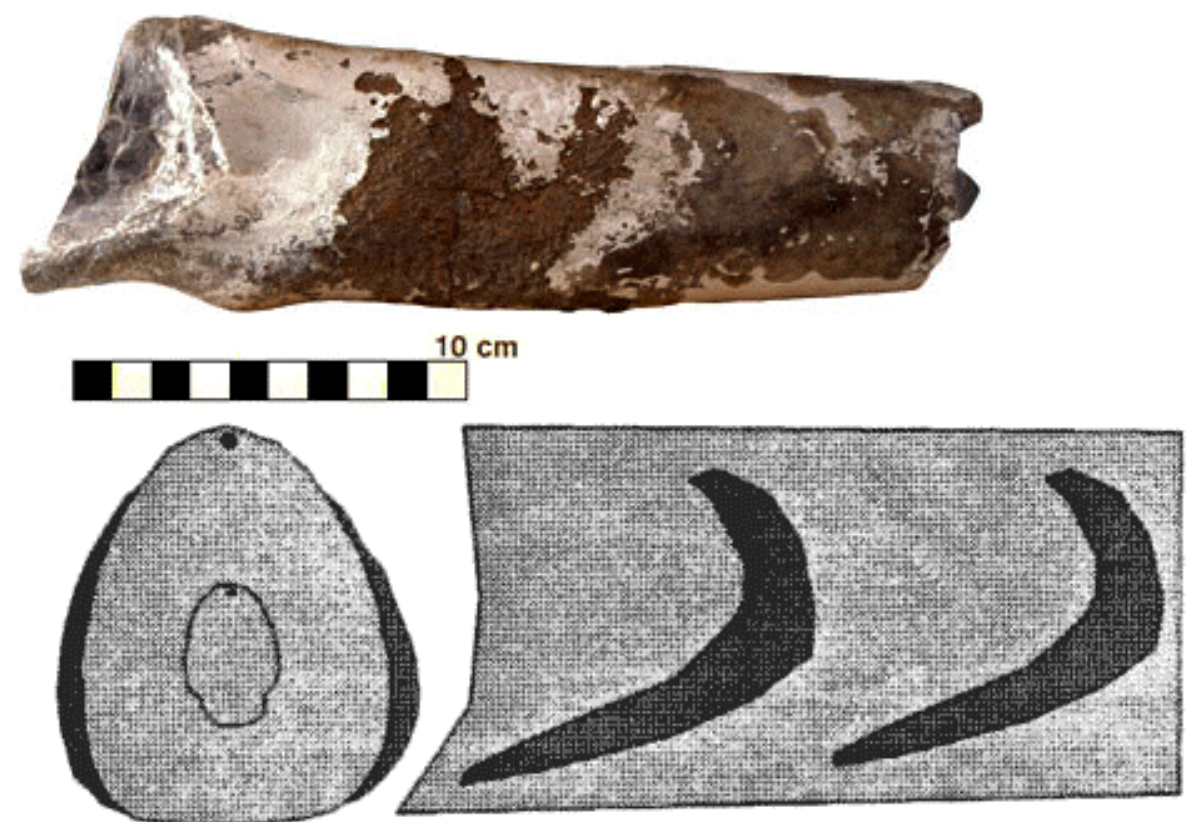

\section{cm}

Figure 32. Baculites clinolobatus is a biozone range fossil of the Mobridge Member of the Pierre Shale. The species is similar to Baculites grandis in size, but has more arcuate flank ribbing and is more triangular in cross section in its adult form. Mobridge facies occurs throughout the park and region. This specimen is from the northern Sage Creek area near Wasta, South Dakota. 


\section{Elk Butte Facies}

W.V. Searight (1937) established the Elk Butte Member of the top portion of the Pierre Shale. Unlike the underlying Mobridge Member, the Elk Butte is noncalcareous. In the Type area on Rattlesnake Butte in Corson County, South Dakota, the Elk Butte member is gradational with both the underlying Mobridge and overlying Fox Hills Formation. Elk Butte facies are recognizable in the park (fig. 33). Because of the noncalcareous character of the shale, shell fossils are rare. In the lower part of the Elk Butte facies, a small, unnamed species of baculite is fairly common (fig. 34). In addition, the coiled ammonites, Hoploscaphites melloi (fig. 35) and Hoploscaphites birkelundi (fig. 36) have been recovered from this interval throughout the park region. In northwestern South Dakota and in Wyoming, Hoploscaphites birkelundi occurs in sandstone facies of the Fox Hills Formation, whereas in the Badlands region and along the Missouri River valley this species is found in Pierre Shale (Elk Butte facies).

The designation as Elk Butte Member in Badlands National Park is based on fossils and lithologic appearance and stratigraphic position (similar to exposures in the Missouri River Valley region). In contrast to the Missouri Valley region, the Fox Hills rests on an unconformable surface on the Elk Butte and older units in the Badlands region. In the area, the thickness of the Elk Butte is highly variable ranging form nearly 50 meters along the White River south of Kadoka, to possibly missing along the crest of an anticline in the southern Sage Creek Wilderness Area where the Fox Hills rest unconformably on the Mobridge Member. These unconformable relations, particularly across the crest of anticlines, demonstrate that Laramide tectonism was actively occurring in the Badlands region while marine sediments were being deposited in the Late Cretaceous.

Elk Butte facies (bearing Hoploscaphites melloi) occurs along the upper tributaries of East Fork along the southern side of the Sage Creek Anticline in the Grassy Table Overlook area. It also occurs at creek level in the core of the Sage Creek Anticline in the Dillon Pass/Conata Creek Basin area. In these areas, shale exposed along creek level is very dark-gray and fissile, and contain large, barren, light-gray colored concretions that lack fossils.

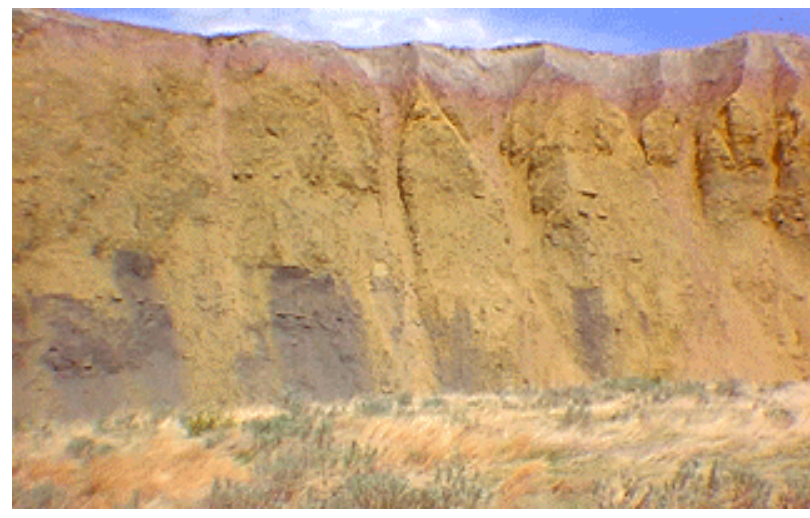

Figure 33. Elk Butte facies (gray) crops out beneath mudrock and sandstone beds of the Fox Hills Formation (brown) along Middle Fork in the Sage Creek Wilderness area. Thin bentonite beds and concretion layers in the Elk Butte facies reveal information about series of small gentle anticlines and synclines throughout the Sage Creek Wilderness Area and surrounding region. 


\section{Baculites - an unnamed species (Stoffer, 1998)}
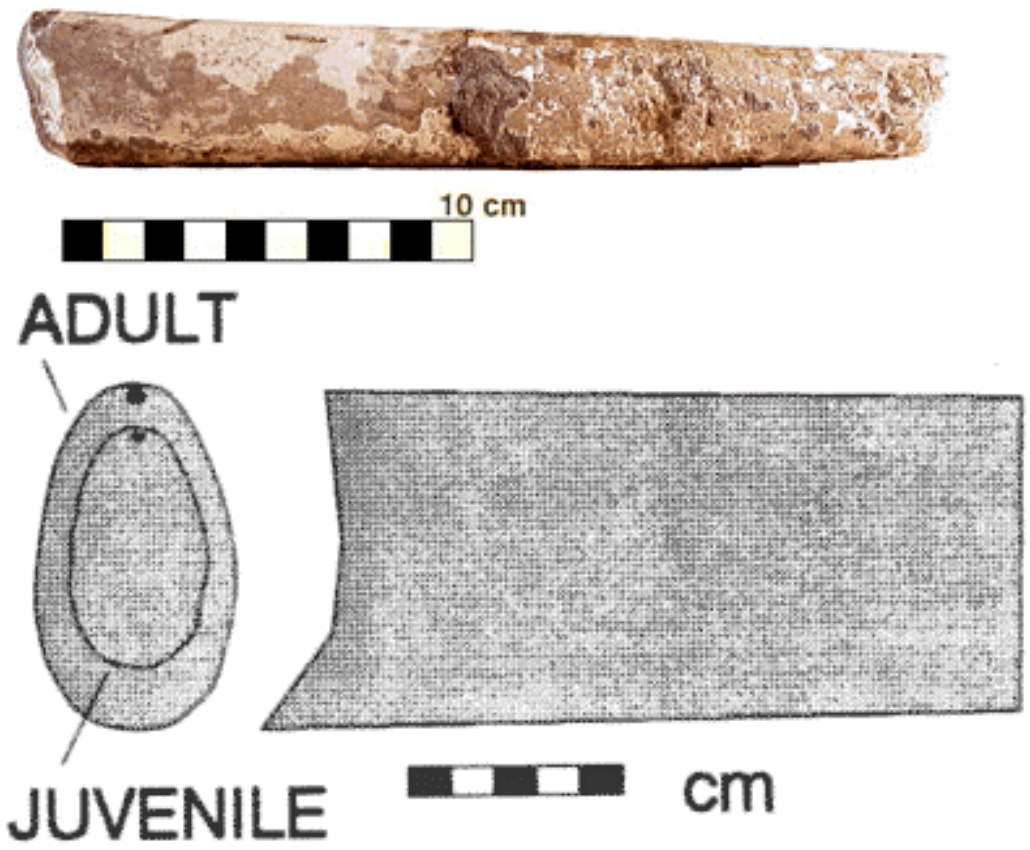

Figure 34. An unnamed variety of baculite occurs in the upper Mobridge and lower Elk Butte facies of the Pierre Shale throughout the park area. The character of the fossil is inconsistent with descriptions of other species of this interval described elsewhere (being thinner and less-tapered than other more "robust" species (Baculites clinolobatus or Baculites larsoni). Its abundance in the park area, particularly in reworked lag deposits higher in the section, gives it significance for field investigations in the region. A suggested name presented here would be Baculites sagensis (it is perhaps the most common fossil in the uppermost portion of the Pierre Shale exposed through the Sage Creek Wilderness Area). 


\section{Hoploscaphites melloi (Landman and Waage, 1993)}
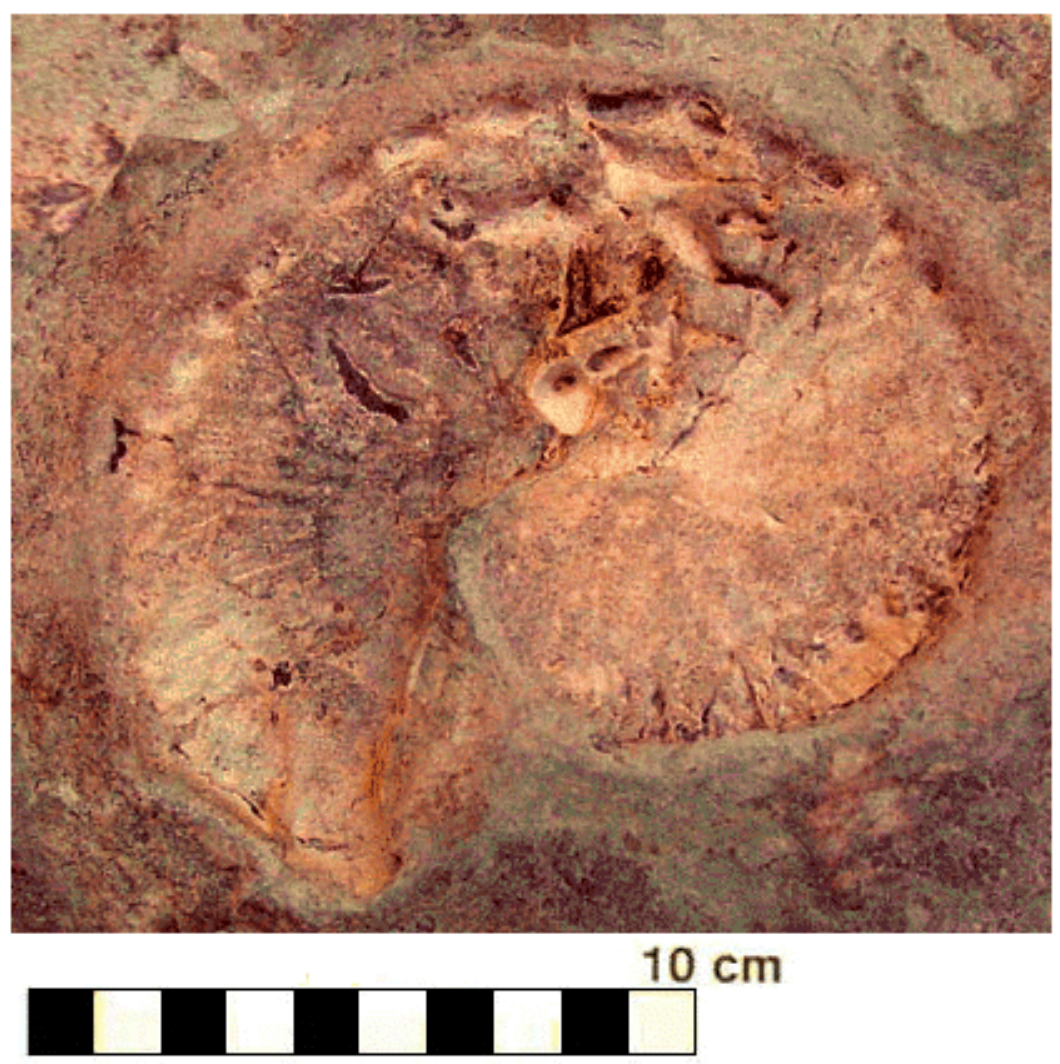

Figure 35. Hoploscaphites melloi is a range fossil of the upper Elk Butte Member of the Pierre Shale in the Missouri River valley region. Elk Butte facies occurs throughout the park and region, however, it is locally missing beneath the Fox Hills and White River Group along the crest of anticlines, such as along South Fork of Sage Creek in Badlands NP's North Unit and along Cedar Creek in the South Unit. This specimen displays damage by bioturbation.

\section{Hoploscaphites birkelundi (Landman and Waage, 1993)}

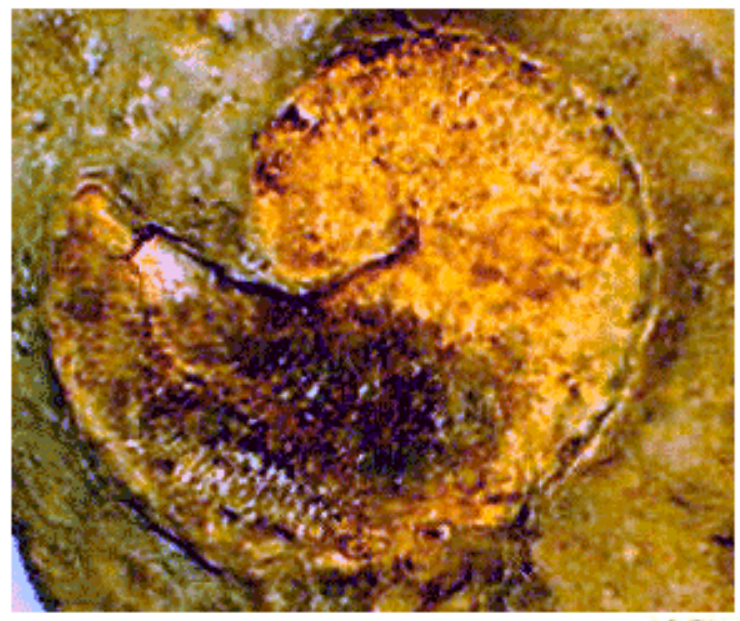

Figure 36. Hoploscaphites birkelundi is a biozone range fossil of the Elk Butte Member of the Pierre Shale in the Missouri Valley region and is known from the lower Fox Hills Formation in the northwestern South Dakota region. It also occurs in the lower Elk Butte facies throughout the park and region. Hoploscaphites birkelundi also occurs in sandy facies of Fox Hill Formation west of the Black Hills.

\section{$10 \mathrm{~cm}$}




\section{Fox Hills Formation}

Meek and Hayden (1862) identified the Fox Hills Formation (Formation No. 5 of the Cretaceous) to encompass the interval between the underlying Pierre Shale and the overlying Tertiary Fort Union Group. They described the interval as being widespread, ranging from the Fox Hills (along the Moreau River, a tributary of the Missouri River) to as far was as the eastern flank of the Bighorn Mountains and along both the North and South Platte Rivers (Agnew and Tychsen, 1965). The Fox Hills is now recognized as a complex series of Maestrichtian-age sedimentary facies (marine, transitional, and terrestrial) that interfinger across the Western Interior region, with detailed relationships largely unresolved across the region. The complexity of the Fox Hills is demonstrated with ammonite biozonation, particularly where different ammonite range zones are known to cross various lithologic facies. For instance, Robinson and others (1959) demonstrate that the ammonite range zones of the Pierre Shale starting with Baculites eliasi and higher occur in sandy lithology assigned to the Fox Hills Formation along the northern flank of the Black Hills. Conversely, the youngest ammonite species associated with sandy lithofacies of the Fox Hills Formation along the Grand River in northern South Dakota occur in Elk Butte shale lithofacies in southern South Dakota.

The most thoroughly investigated exposures of the Fox Hills Formation are in northern South Dakota along the Grand River valley where highly fossiliferous units have been the targets of many paleontological investigations. Karl Waage (1968) formally established a Type designation to that region and assigned members based on both lithologic and paleontological content. Because the lithology of the Fox Hills varies considerably across the region, only the paleontological content is truly suitable for correlation. Waage named four members of the Fox Hills Formation, and only the two lowest members in the Type area contain abundant fossils, the Trail City Member (lower) and the Timber Lake Member (middle). Two upper terrestrial units include the Colgate Member and Iron Lightning Member. How these different members correlate across the region is not clear. The descriptive differences between Fox Hills Formation and Hell Creek Formation in South Dakota are quite muddled. The most simplistic lithologic breakdown seems to be recognizable as follows: if it is shale and has marine fossils it is Pierre Shale; if it is sandy and contains marine fossils then it is Fox Hills; and if it is of terrestrial origin and contains plant material and (or) dinosaur bone then it is Hell Creek. However, these rules are rarely recognized. The different facies were likely deposited concurrently in different parts of the region.

A generalized regional correlation for the Fox Hills and other stratigraphic units are shown below (fig 37). The eastern Wyoming section follows a Type description by Gill and Cobban (1966). However, Pettijohn (1967) established a type area for the Hills Formation in the region around the town of Faith, South Dakota in the northwestern portion of the state. In addition, Karl Waage (1968) established a type description of the Fox Hills in the Grand River Valley region in the northern Missouri River Valley of South Dakota. Confusion remains relating to the inferred position and relative ages of units described as "Hell Creek Formation" throughout the Western Interior region. Dinosaur bearing beds are included in the White Owl and Stoneville Coal facies by Pettijohn (1967). Whether these units are equivalent to dinosaur bearing strata of the Hell Creek elsewhere in the region is unresolved. However, correlation of the Badlands section presented here basically follows terminology of both the northwestern South Dakota and Missouri Valley sections (following descriptions by Pettijohn and Waage).

According to Gill and Cobban (1973) the Fox Hills represents shallow marine, marginal, and terrestrial deltaic facies that prograded eastward from the Montana/Wyoming boarder region. Units such as the upper Timber Lake Member in the Type area of South Dakota and in eastern Wyoming consist of a massive cross-bedded sandstone sequence. The lack of equivalent sandstone facies in the Badlands area suggests that either the units are missing (due to erosion) or that progressive uplift of the Black Hills, the Chadron Arch, and other structural elements including the Sage Creek Arch (or anticline) may have prevented an influx of sediment into the Badlands region during Early to Late Maestrichtian time. It is likely that both theories may apply. 


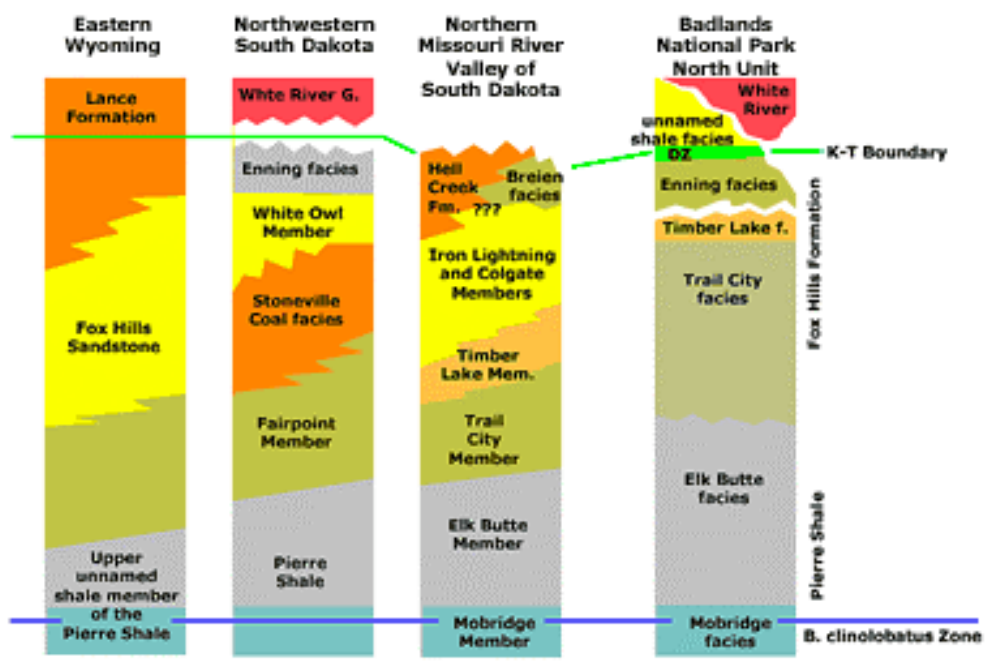

Figure 37. Regional correlation of the Fox Hills Formation.

The Fox Hills Formation in the Badlands National Park region is unlike exposures of the formation in Wyoming or in its Type area in the northern Missouri River Valley region of South Dakota, and is therefore undifferentiated in the park area. However, characteristics of the Badlands' Fox Hills share some similarities with other areas, particularly its fossil content. Because of these similarities, the geologic story revealed by strata exposed in Badlands National Park can be interpreted.

In general, sandy facies of the Fox Hills Formation is thin or missing along the eastern flank of the Black Hills and is difficult to resolve in the Badlands region. Strata that better fits a lithologic description of Fox Hills (rather than Pierre Shale) occurs as thin ledge-forming sandstone beds that cap the hilltops throughout the southern Sage Creek Wilderness area (especially along the South and Middle Forks of Sage Creek. In the hilltops around the Sage Creek Campground, large, brown weathering, ironstone concretions crop out amongst sandy mudstone and shale. These upper units of Cretaceous section have been heavily altered by meteoric exposure prior to deposition of the basal Chadron Formation (alteration by pedogenesis associated with the Yellow Mounds and Interior paleosols). However, in this weathered interval, casts of fossils, arthropod parts, fossil wood, and rare sharks teeth occur.

East of the Sage Creek Campground area in the vicinity of White Butte, a moderately irregular unconformable surface is preserved beneath sediments that appear to fill channels carved into the upper Pierre Shale along the crest of the Sage Creek Anticline. A brown, ledge-forming hardpan has developed intermittently along this surface. It can be traced throughout the hilltops along the valleys of the Middle and South Forks of Sage Creek (fig. 38). Specimens of the ammonite, Hoploscaphites melloi (a fossil known from the Elk Butte Member in the Missouri River valley), were recovered from below this boundary. Fossils typical of the Trail City Member (of the Missouri Valley region) were observed above this layer. In the Type area for the Fox Hills, the coiled ammonite, Hoploscaphites nicolletii occur locally in abundance in the Trail City Member (fig. 39). Although no specimens of this species have been found in the park, examples have been recovered from along the Cheyenne River valley north of the park.

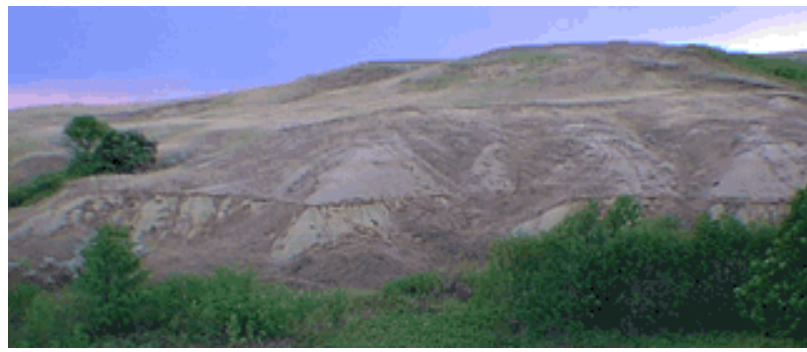

Figure 38. An ironstone concretion layer highlights an unconformity separating Elk Butte facies from the overlying marine shale of the lower Fox Hills Formation (near White Butte about 2.5 miles east of the Sage Creek Campground). The layer begins just below the trees on the left. 


\section{Hoploscaphites nicolletii (Landman and Waage, 1993)}

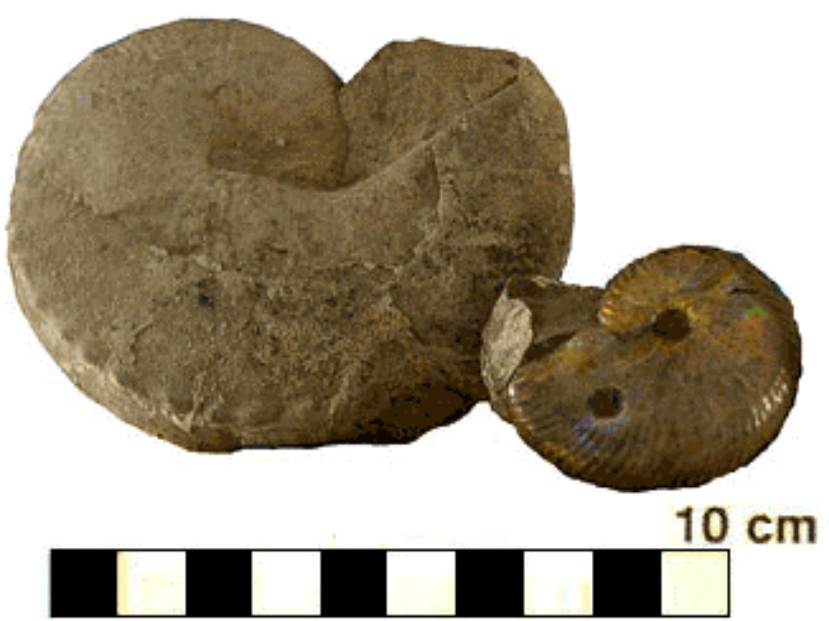

Figure 39. Hoploscaphites nicolletii is a biozone range fossil of the Trail City Member of the Fox Hills Formation in the Missouri River valley region (where it occurs locally in abundance). Although the fossil has not been found in the park, it has been observed in the vicinity including along the upper hillsides along the east side of the Cheyenne River valley near Wall, South Dakota. These specimens are from the Grand River area near Timber Lake, South Dakota.

Higher in the section, the sediment color fades from pale gray to buff and brown colors, and beds of large, reddish brown, fine-sandy textured concretions occur. These concretions commonly merge to form a bench-like surface along hillsides throughout the park area (fig. 40). Amongst the red concretions specimens of Jeletzkeytes nebrascensis have been recovered. This species is an index fossil for the Timber Lake Member of the Type Fox Hills in the Missouri Valley region (Landman and Waage, 1993). It is also the youngest ammonite zone fossil of the Late Cretaceous (Kennedy and others, 1998).

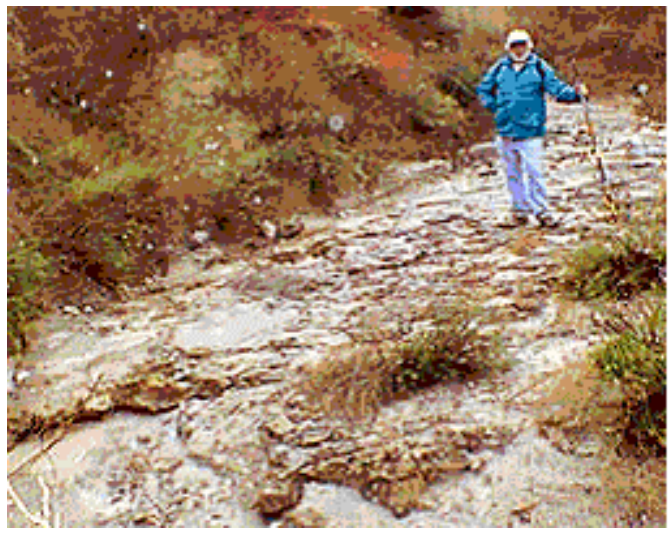

Figure 40. A red concretionary sand layer typical of Timber Lake facies is exposed in Conata Creek near the Dillon Pass area.

Above the concretionary sandstone is an interval of green- and red-colored fossiliferous marl that yields ammonites, belemnites, fish remains, plant material, tiny clams, oyster fragments, and other material (fig. 41). Pettijohn (1967) described belemnites and other marine fauna in his Enning facies at the top of the Fox Hills in northern South Dakota.

Ammonites from this interval have been identified as Jeletzkeytes nebrascensis (fig. 42). However, belemnites (Belemnitella bulbosa) are perhaps the most common fossil from this interval (fig. 43). Belemnites are also known from the Timber Lake Member in the Missouri Valley region. Also, Jeletzkeytes nebrascensis is known from the Breien Member of the Hell Creek Formation in southern North Dakota along the Missouri River valley. In Badlands National Park, this interval (Enning facies) only occurs in 
scattered outcrops along the northern park boundary and north of the park. To the south this interval is not preserved or exposed beneath the White River beds.

Stoffer and others (2001) gave the name Disturbed Zone to a widely distributed interval of soft-sediment deformation above the Enning facies interval throughout the park area (see discussion below). The Disturbed Zone is overlain by as much as 16 meters of alternating sand and shale beds. The maximum thickness of this interval in the park is near the Grassy Tables Overlook in the North Unit. The top of this section grades upward and vanishes into the overlying Yellow Mounds weathering profile. The Disturbed Zone defines the extinction boundary for most Cretaceous species in the park region.

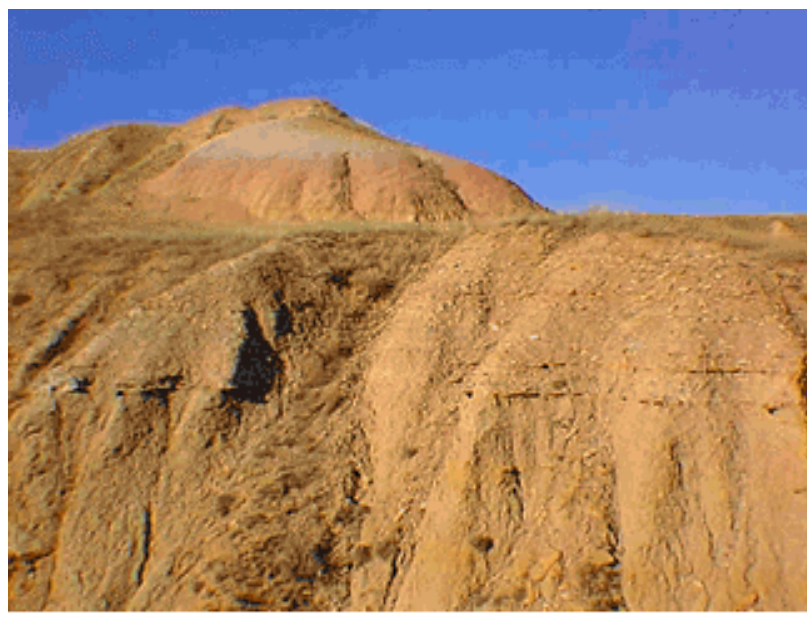

Figure 41. The upper Fox Hills Formation exposed near the Wilderness Access trailhead in Badlands National Park. The lower half of the image consists of "Enning facies"- a brown marl (bearing belemnites) of the upper Jeletzkeytes nebrascensis Zone. Just above the lower half of the image is a sand bed. In this outcrop vicinity this sand sheet (up to $20 \mathrm{~cm}$ thick) locally occurs along at the base of the Disturbed Zone. The top of the section consists of alternating sand and shale beds that grade upward into the Yellow Mounds weathering profile (paleosol). The small "yellow mound" in the upper left of this image is capped by gray mudrock of the Chadron Formation.

\section{Jeletzkeytes nebrascensis (Landman and Waage, 1993)}

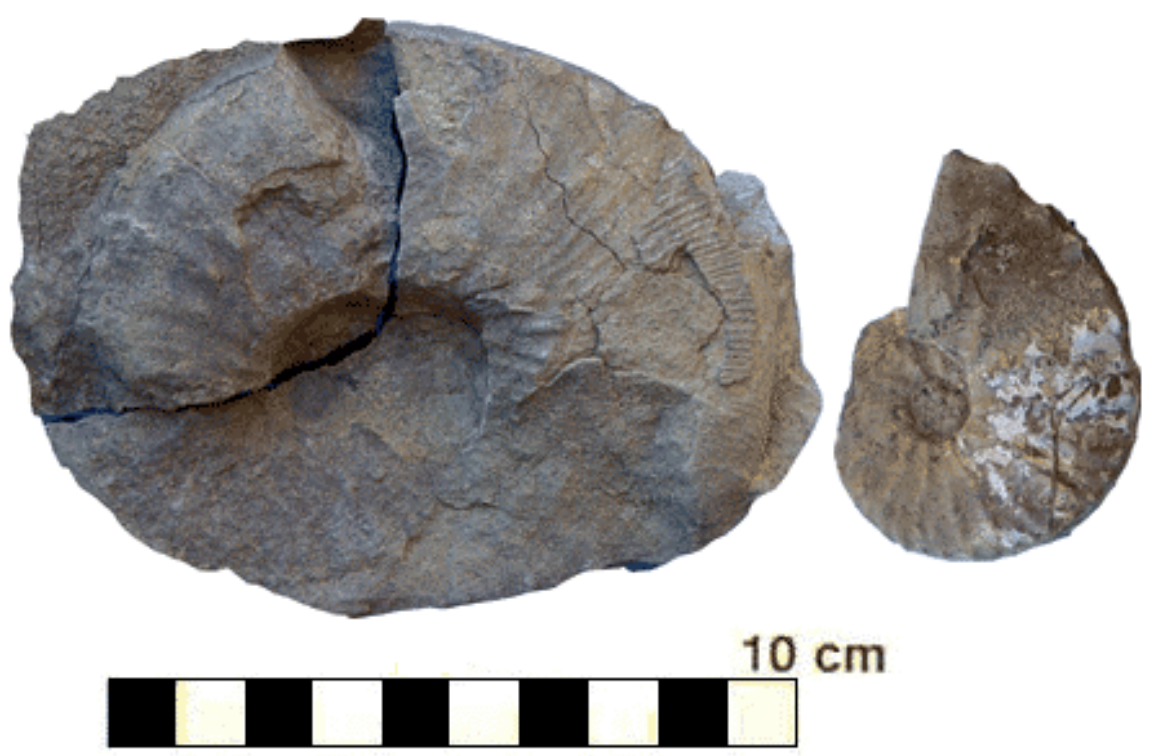

Figure 42. Jeletzkeytes nebrascensis is a biozone range fossil of the Timber Lake Member of the Fox Hills Formation in the Missouri River valley region. It occurs in Timber Lake facies in the park and region. These specimens are from the national grasslands north of the park (southwest of Wall, South Dakota). 


\section{Belemnitella bulbosa (various subspecies)}

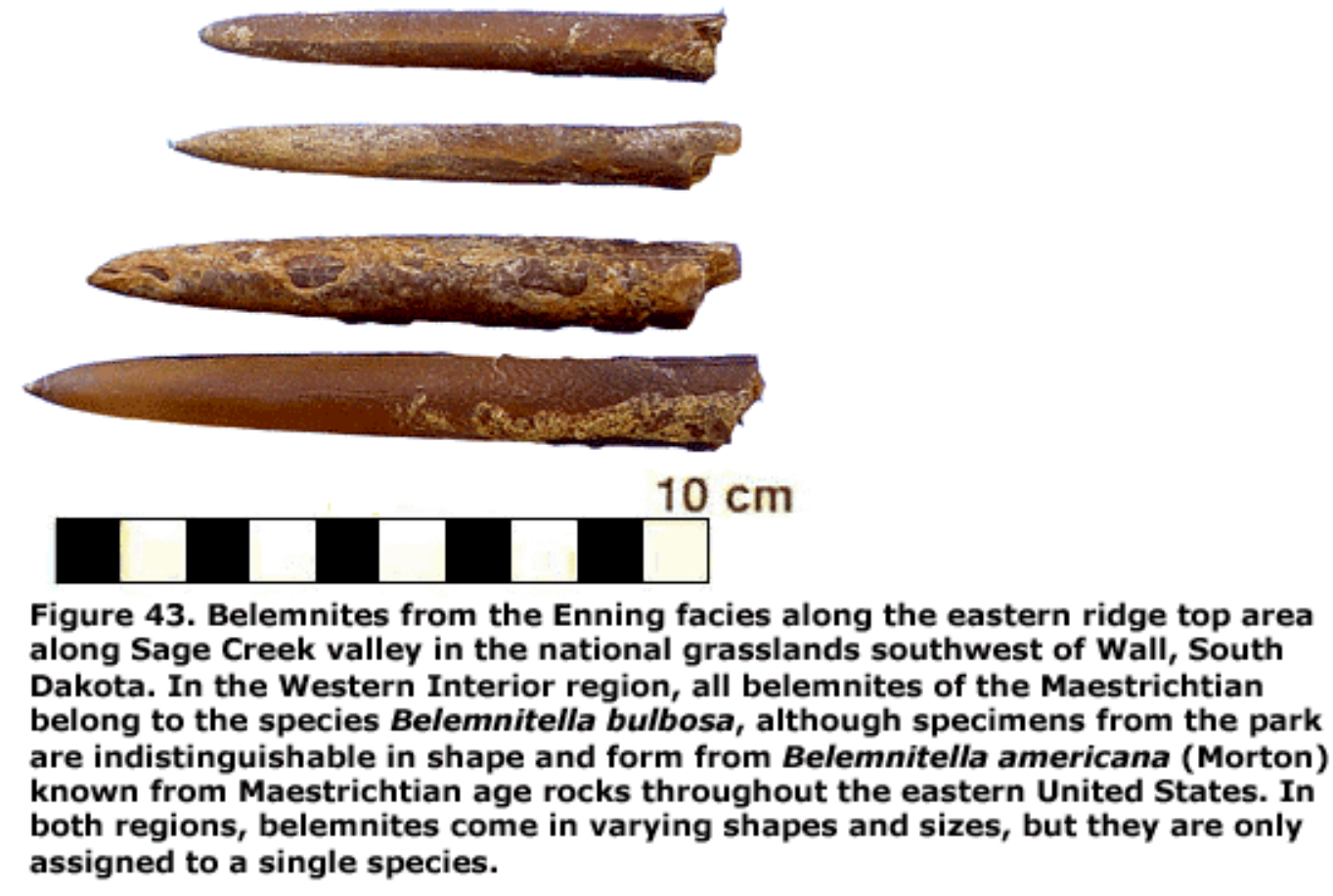

Although belemnites have been reported from many units in the Pierre Shale throughout the Western Interior region, the only reported occurrence of belemnites in the park and vicinity is from the upper Timber Lake and Enning facies of the Fox Hills Formation. Pettijohn (1967) described belemnites from his "Enning facies" in his original description of the Fox Hills section in northwestern South Dakota. The Enning facies consists of marine shale and marl beds (bearing belemnites, oysters, and other marine fauna) and represents a marine incursion during the Late Maestrichtian. In Pettijohn's study area, these marine shales overlie terrestrial sandstone units bearing dinosaur fossils. This underlying dinosaur-bearing strata is included in "Hell Creek Formation" in most of the literature about the northwestern South Dakota region. However, no dinosaur bearing beds are been found in the park region.

Strontium isotope geochronology data derived from belemnites recovered from the Enning facies in Badlands National Park have yielded age values of latest Maestrichtian age. ${ }^{87} \mathrm{Sr} /{ }^{86} \mathrm{Sr}$ sample values derived from Enning facies belemnites range from 0.707801 to 0.707821 (Stoffer and others, 2001). Dennis Terry (personal communication, 2002) reevaluated this belemnite data using revised ${ }^{87} \mathrm{Sr} /{ }^{86} \mathrm{Sr}$ geochronology data presented by McArthur and others (1998) and came up with an age of 66.3 million years (within a 95 percent confidence interval). This age determination is fundamental to the interpretation that the Disturbed Zone in the Badlands National Park region is associated with the Cretaceous-Tertiary boundary. 


\section{The Cretaceous-Tertiary Boundary Interval in Badlands National Park}

A possible Cretaceous-Tertiary (K-T) boundary interval has been recognized in marine strata in Badlands National Park. The boundary is associated with a widespread unit displaying soft-sediment deformation (0.5 to $4 \mathrm{~m}$ thick) called the Disturbed Zone (Stoffer and others, 2001; Terry and others, 2001). This bed is within a thicker interval historically described as the Interior zone (Raymond and King, 1976). In historical usage, the Interior Zone encompasses all a brightly colored series of beds that falls between gray marine mudrocks of the Pierre Shale and the base of the White River beds (fig. 44).

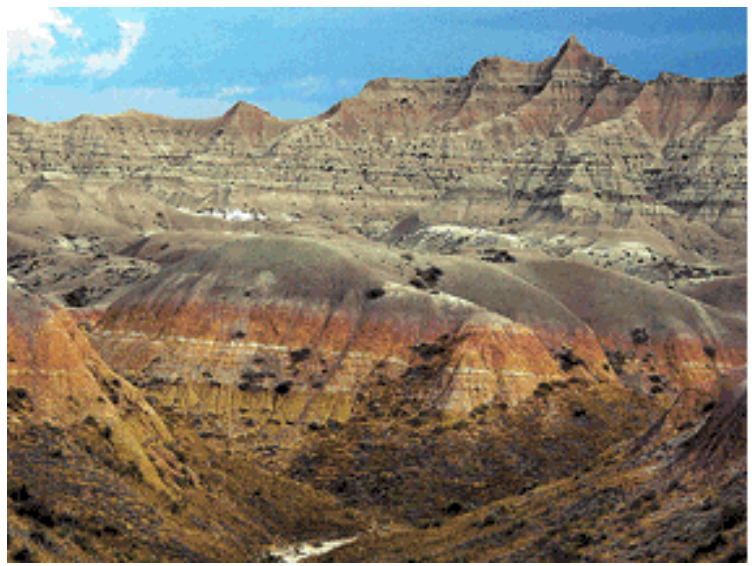

Figure 44. The traditional "Interior zone" included the brightly colored beds between creek level and the base of the gray mudrock of the Chadron formation (show here in the center of the image). Recent data and paleontological discoveries support interpretations that the brightly colored beds represent sedimentary deposits that span ages from the Late Cretaceous to the Eocene.

The Interior Zone within the North Unit of Badlands National Park is now subdivided into a series of identifiable units based on fossil content and lithologic characteristics (fig. 45). In the North Unit of the park, the majority of the parent rock for the Interior zone is now assigned to the Fox Hills Formation and a series of sediments and fossil soil horizons (paleosols). All Fox Hills and younger units are variable in their thickness, composition, and appearance across the park region. In particular, sandstone facies thin and vanish southward across the park region.

\begin{tabular}{|c|c|c|c|c|}
\hline & 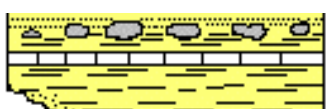 & \multirow{2}{*}{\multicolumn{3}{|c|}{$\begin{array}{l}\text { Chadron Formation } \\
\text { (Interior paleosol) }\end{array}$}} \\
\hline & & & & \\
\hline $0-4$ & & \multicolumn{3}{|c|}{$\begin{array}{r}\text { Chamberlain Pass Formation } \\
\text { (Yellow Mounds paleosol) }\end{array}$} \\
\hline $0-16$ & & \multicolumn{2}{|c|}{ unnamed marine facies } & \\
\hline $0-3$ & & \multicolumn{2}{|c|}{ K-T? $\quad$ Disturbed Zone } & \\
\hline $0-8$ & & \multirow{2}{*}{\multicolumn{2}{|c|}{$\begin{array}{l}\text { Bellemntella bulbosa Enning facies } \\
\text { Jeletzkeytes nebrascensis } \\
\text { Timber Lake facies }\end{array}$}} & 운 \\
\hline \multirow[t]{2}{*}{ 6-26 } & & & & $\frac{\underline{n}}{\bar{x}}$ \\
\hline & 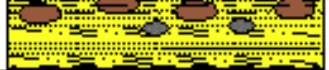 & | Hoploscaphies nicollet & Trail City facies & ố \\
\hline
\end{tabular}

Figure 45. With traditional local usage, the "Interior zone" encompassed the stratigraphic interval between "unaltered Pierre Shale" and the base of the Chadron Formation. The subdivisions presented here are an interpretation with nomenclature for the sections exposed in the North Unit. 


\section{A Historical Perspective on the Interior Zone}

The Interior zone has a long history of debate and discovery. In the days when the Badlands region was still part of the Nebraska Territory, the Nebraska Geological Survey used the name "Rusty member of the Pierre" for the brightly colored interval between the gray mudrocks of the Pierre Shale and the base of the overlying White River beds. This was in recognition that the interval displayed evidence of heavy weathering or leaching prior to deposition of the sediments of the Chadron Formation. Interpretation of the interval was delayed by the general lack of identifiable fossils.

Freeman Ward (1922) first used the name "Interior phase of the Pierre" to describe the brightly colored sequence of beds west of Interior, South Dakota. Later, Ward (1926) concluded that the Interior beds were in part equivalent to Fox Hills Formation.

Meanwhile, H.R. Wanless (1923) recognized that the Interior Zone also represented an interval of weathering and leaching, and that the upper surface of the Interior interval was irregular beneath the base of the overlying Chadron Formation of the White River Group. Much later, R. J. Dunham (1961)

demonstrated that on a regional scale the weathered surface on the Pierre Shale in the Badlands region formed on surfaces that ranged as far down in the section as the Niobrara formation and up section to overlie Eocene sediments. He concluded that the surface was of Eocene age. Pettijohn (1966) expanded this investigation across the region and demonstrated that what he named the "Yellow Mounds weathering profile" was of Late Eocene age and could be found imprinted on sediments ranging in age from Late Cretaceous to middle Eocene. He name the Yellow Mounds after a series of small yellow mounds resting on Fox Hills Formation in the vicinity of the Wilderness Access trail head in the Badlands North Unit (fig. 46).

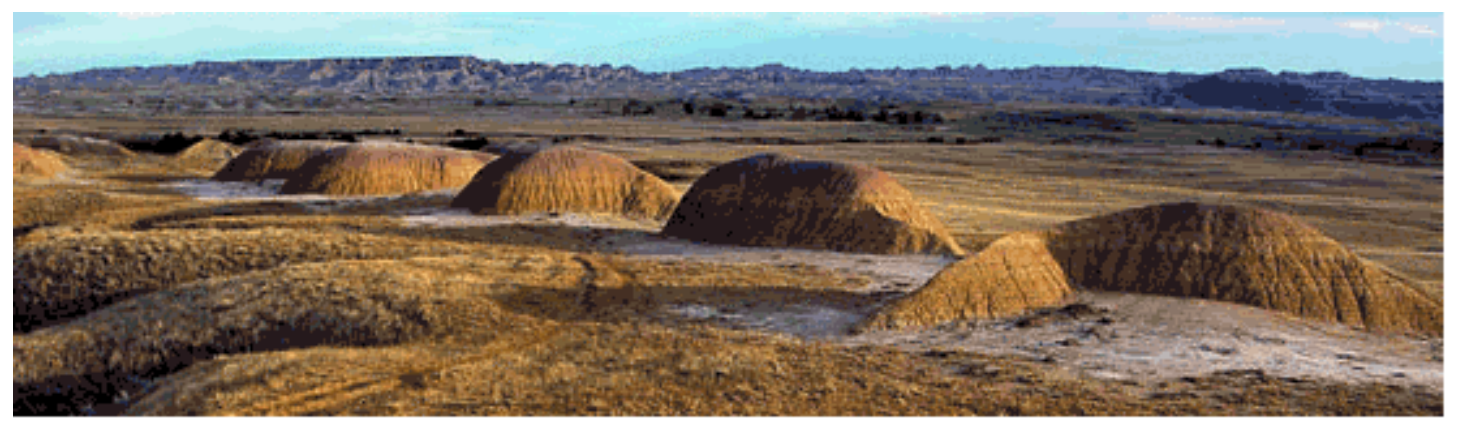

Figure 46. The traditional "Yellow Mounds" near the Wilderness Access trailhead.

Retallack (1983) also investigated the Interior zone while investigating ancient soil profiles in the White River Group. He concluded that a series of paleosols and channel sandstones were established on an irregular surface of Pierre Shale and possibly Fox Hills, but added that a sandy unit below the base of the Chadron may be equivalent to the Slim Buttes Formation (an Eocene unit in northwestern South Dakota). Following Pettijohn's weathering profile interpretation, Retallack used the name "Yellow Mounds" to describe an older weathering profile below the "Slim Buttes" unit, and limited the name "Interior" to the red fossil soil profile developed on top of this bed.

Terry and Evans (1994) later established that stream channel and flood plain deposits are locally preserved beneath the base of the Chadron Formation and that these deposits are crosscut by incising channels at the base of Chadron Formation. Terry also identified an Eocene mammal tooth within the unit and concluded that some of the sediments were derived from the Black Hills region. He assigned the name Chamberlain Pass Formation to flood plain and stream channel sediments overlying the Yellow Mound Surface and below and including the Interior paleosol.

Establishing the age of youngest identifiable species in the original sediments imprinted by Yellow Mounds weathering profile is an ongoing task. Gill and Cobban (1966) and Landman and Waage (1993) established ammonite biozonation for the Pierre Shale and Fox Hills Formation in the region. Stoffer (1998) correlated 
many of these ammonite biozones to the park area. Evaluating sedimentation rates based on established ammonite ages, Stoffer and others (1998) concluded that the stratigraphic section of the upper Pierre ShaleFox Hills interval in the northern park region was too thick not to consider that some of the upper section beneath the Yellow Mounds may be Paleocene in age. However, the possibility that the park section encompassed the Cretaceous-Tertiary boundary wasn't possible until belemnite fossils were discovered and dated using strontium-isotope geochronology. These fossils yield ages that ranged upward into the Late Maestrichtian. These belemnites were recovered from sediments immediately below a zone of widespread soft-sediment deformation (the Disturbed Zone). Initial investigations suggest that this interval may be associated with the terminal Cretaceous asteroid impact, or impacts (Stoffer and others, 1997; 2001). In the park and above the Disturbed Zone are a maximum of $16 \mathrm{~m}$ of drab-colored marine sediments beneath the Yellow Mounds interval. This interval is designated the name Unnamed marine facies of the Fox Hills Formation. This interval increases in thickness north of the park.

\section{The Disturbed Zone}

The Disturbed Zone (DZ) is a zone of soft-sediment deformation occurring throughout the northern Badlands National Park region. Stoffer and other (1997) first described the interval as a buried slump horizon in the upper Pierre Shale along the crest of the Sage Creek Anticline. However, additional investigations by Stoffer and others (2001) demonstrated that the Disturbed Zone is a relatively continuous stratigraphic unit throughout the region ranging in thickness between several meters to less than a meter. This discussion provides a description of the DZ along with basic evidence that suggests the origin of the deposit corresponds with a widespread natural catastrophe that drastically changed environmental and ecological conditions in the Western Interior Seaway region. Whether this deposit is a result of a great asteroid impact associated with the Cretaceous-Tertiary boundary will no doubt be discussed for generations. A map showing the location of selected DZ localities is shown in fig. 47.
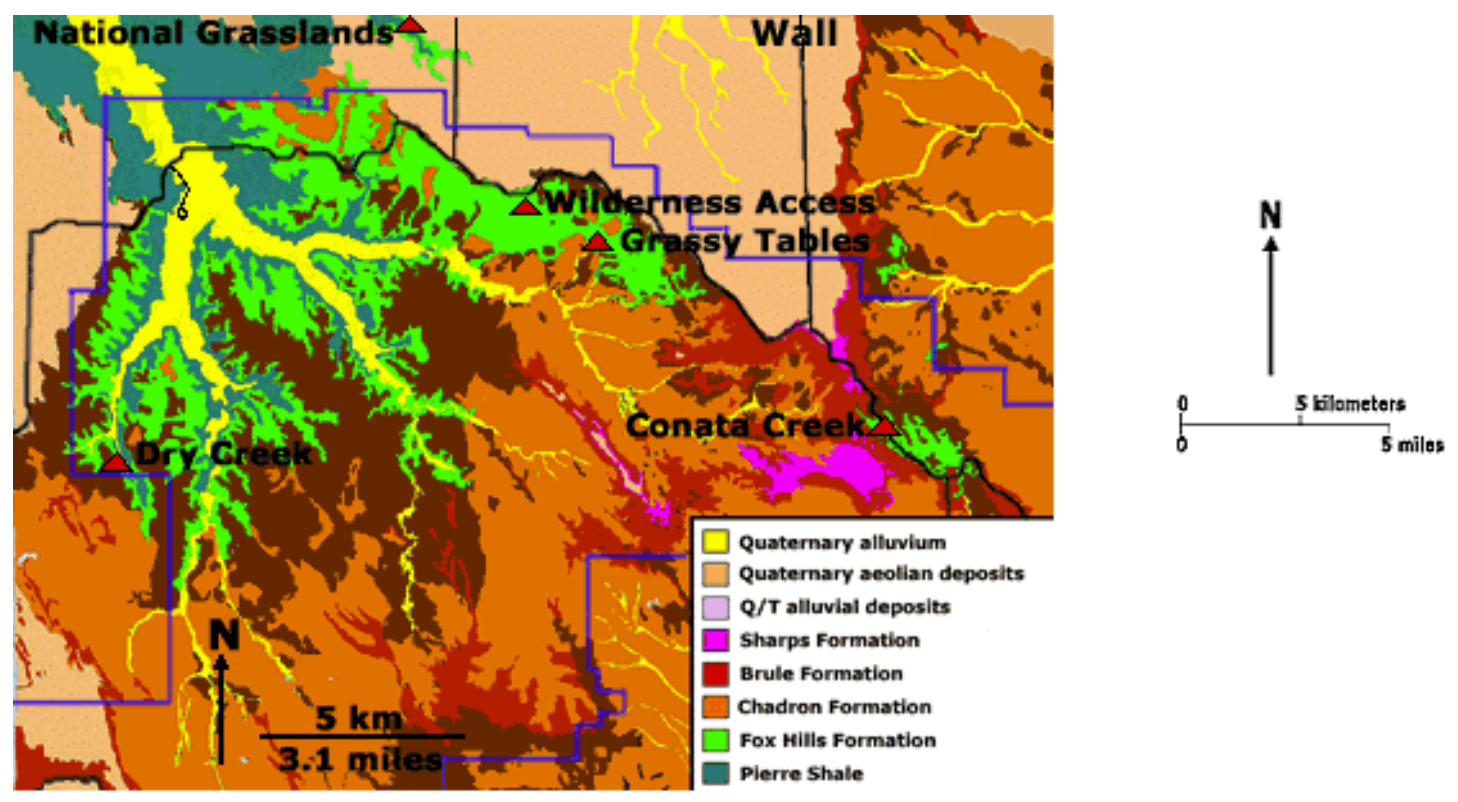

Figure 47. Outcrops where features within this interval are well exposed are shown on the geologic map of a portion of the northern park region below. Red triangles (with labels) indicate selected sites discussed in this report.

Supporting evidence that the DZ represents the K-T boundary includes petrography data, magnetostratigraphy, sequence stratigraphy, and paleontological analyses (see Stoffer and others, 2001). However, perhaps the best physical evidence is easily seen on outcrops in the field. Highlights of the evidence includes: 
A rich, diverse Late Cretaceous marine fauna occurs below the DZ (including ammonites, belemnites, mosasaurs, and inoceramids). No fossil remains of these organisms have been recovered from sediments above the DZ.

The DZ is mappable throughout the northern portion of the park across a region at least $25 \mathrm{~km}$ wide and extends north of the park at least $30 \mathrm{~km}$, and perhaps further. The bed is a result of widespread displacement of seabed sediments across the region.

Up to $16 \mathrm{~m}$ of drab-colored marine beds (alternating sand and shale beds) occur in the thickest section preserved above the DZ. The interval is rich in trace fossils, but has not yielded Cretaceous fauna. The identified fossils and traces in this upper interval all have modern descendents (such as barracuda, sharks, oysters, sand fleas, etc.).

All DZ outcrops display oriented roll structures (sediment layers that were rolled up like a carpet while they were still soft and pliable).

All roll structures display an east-to-west orientation in outcrop (indicating that sediment movement was toward the south).

The interval ranges in thickness between about half of a meter to as much as 4 meters wherever it is exposed (average about $1 \mathrm{~m}$ ).

Other soft-sediment features include clastic dikes, slump glide-plane surfaces, and dewatering structures, none of which penetrate the beds above or below the DZ.

The DZ locally contains charcoal and fragmented plant material.

The sediments above the DZ are flat lying and conformable along a scoured surface. These sediments preserve an abundance of small trace fossils by marine organisms, but the sand and shale beds are not highly bioturbated like the sediments below the DZ. Deep, pervasive bioturbation ended with the event responsible for deposition of the DZ.

The DZ is unique; there are no other examples of other beds or units displaying widespread softsediment-style disruption anywhere else in the exposed stratigraphic section of the Cretaceous or Tertiary in the park region.

The DZ represents a change in depositional conditions in the region. This evidence presented above suggests that the DZ represents the Cretaceous-Tertiary extinction boundary. It is important to emphasize that the sediments both below and above the DZ are marine in origin (see discussion about Unnamed marine facies of the upper Fox Hills Formation below). The preservation of bedding structures above the DZ indicate that a significant crash in the bioturbating seabed fauna occur across the interval. However, the variety of traces preserved in the sand sheets above the zone indicates that small, bioturbating organisms gradually recolonized a shallow marine seabed.

The character and distribution sedimentary features within the DZ indicate that a catastrophic event is associated with its origin. The mix of materials in the DZ show that transport of material occurred with the direction of movement toward the south. The volume of material separated from the seabed is in the range of a meter. Morton (1988) described a similar magnitude of soft sediment deformation caused by a Class 5 hurricane (as Hurricane Camille impacted the sea bed in the gulf region). Similar impacts occur from large tsunamis along coastal regions. However, the disruption across such a large region within the Western Interior Seaway suggests that something possibly larger that a storm or earthquake was responsible for formation of the DZ. 


\section{Conata Creek Locality}

The Disturbed Zone (DZ) is exposed in the headwaters region of Conata Creek where the stream has exposed the "Interior zone" along the Crest of the Sage Creek Anticline. The DZ is visible from the Badlands Loop Road at the Rainbow Colors Overlook site, but other exposures occur along tributaries draining the High Pinnacles area (figs. 48 to 50).

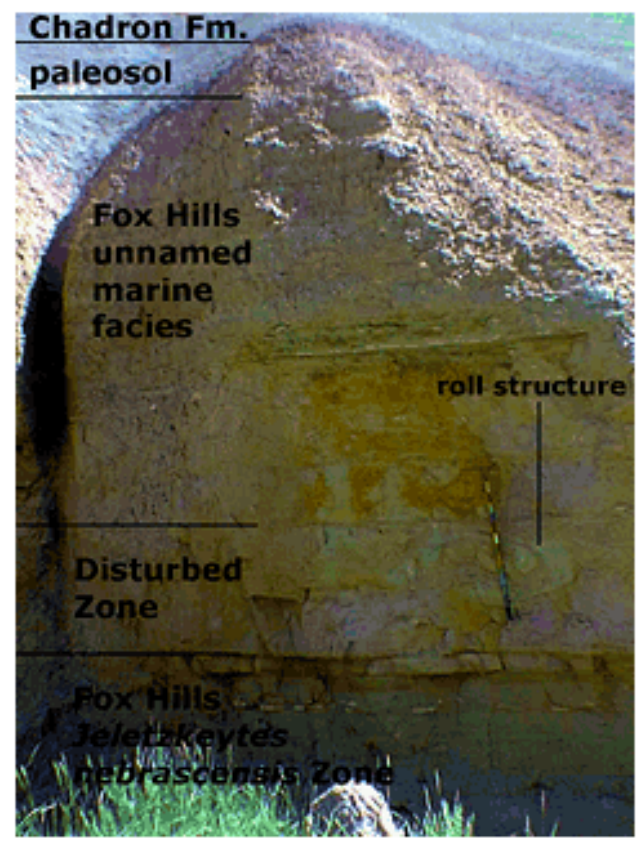

Figure 48. Interpretation of units exposed along Conata Creek northwest of the Rainbow Colors Overlook. Fossils of the upper Jeletzkeytes nebrascensis Zone occur in the sediments beneath a $1 \mathrm{~m}$ thick Disturbed Zone. A cross-section of a roll structure (pale green) stands out in contrast to the surrounding pink-weathered sediments. The $D Z$ is overlain by about $5 \mathrm{~m}$ of marine mudrocks of the Unnamed marine facies of the upper Fox Hills. The Yellow Mounds and the Interior paleosols are thin or missing beneath the base of the Chadron Formation. The walking stick is $1.5 \mathrm{~m}$ for scale.

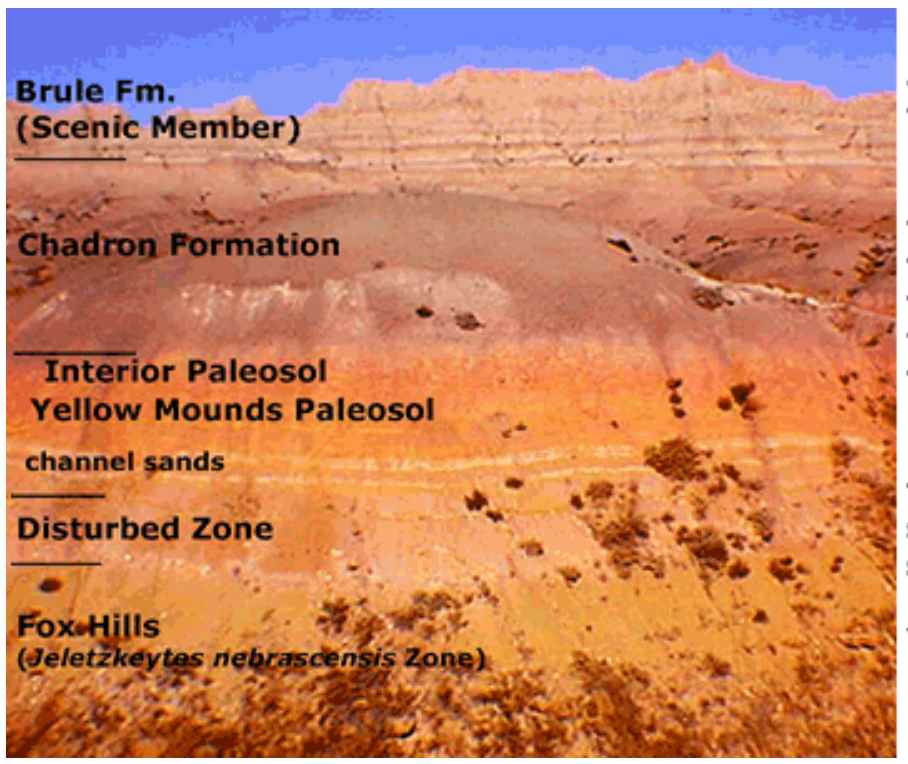

Figure 49. Outcrops visible along the Badlands Loop Road at the Rainbow Colors Overlook also preserve the Disturbed Zone. However, the sediments above the disturbed zone consist of thick white sand sheets that tend to pinch out. Bioturbation features in the sand sheet have the appearance of arthropod burrows, but whether they were marine, brackish water, or freshwater is unclear. These sediments (labeled "channel sands") are overlain and imprinted by the orange-colored Yellow Mounds paleosol and red-colored Interior paleosol. 


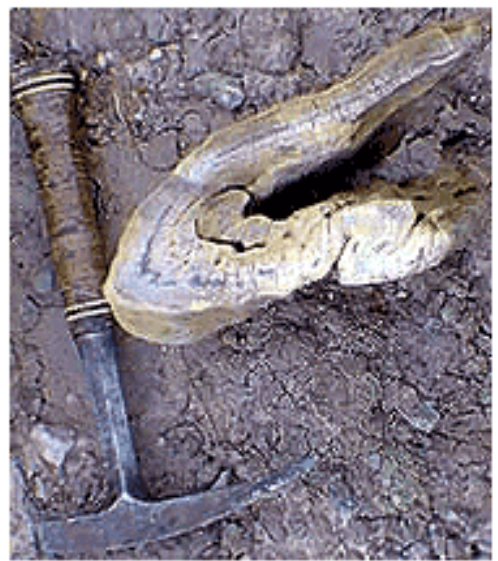

Figure 50. A roll structure from the Disturbed Zone shows detail of soft-sediment deformation. The direction of mass movement illustrated by this sample is toward the right.

\section{Grassy Tables Overlook Locality}

The Grassy Tables Overlook locality is approximate 3 miles directly west of the Pinnacles Ranger Station and south of the Sage Rim Road. It is in the vicinity of several brightly colored hills of the "Interior zone" in the upper Sage Creek Basin. The thickest section of the Disturbed Zone (DZ) is exposed above creek level. It is locally up to $4 \mathrm{~m}$ thick. The section above the DZ consists of about 16 meters of drab-colored marine sediments those grades upward into the Yellow Mounds paleosol. Figs. 51 to 56 illustrate aspects of the upper Fox Hills section in the Grassy Tables Overlook locality.

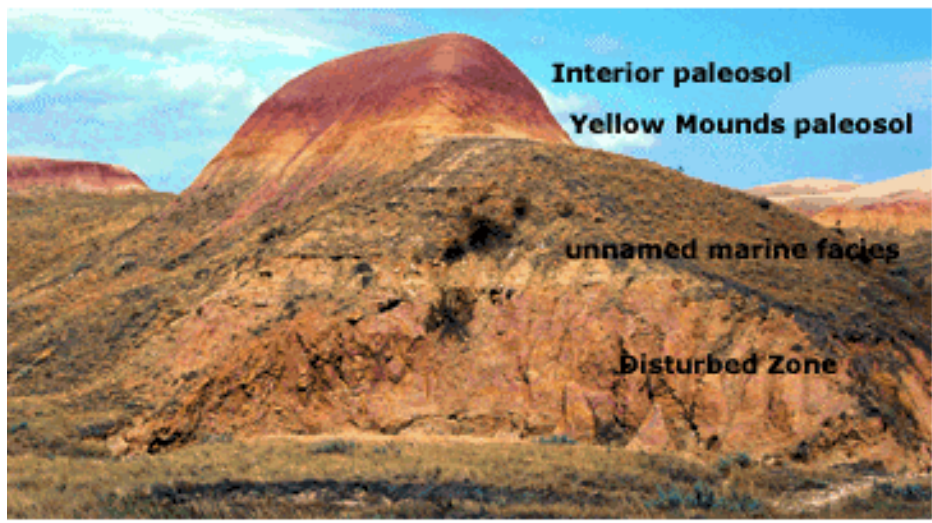

Figure 51. The DZ stands out (pink) below the Unnamed marine facies of the Fox Hills. This exposure is along the East Fork of Sage Creek near the Grassy Tables Overlook along the Sage Rim Road. 


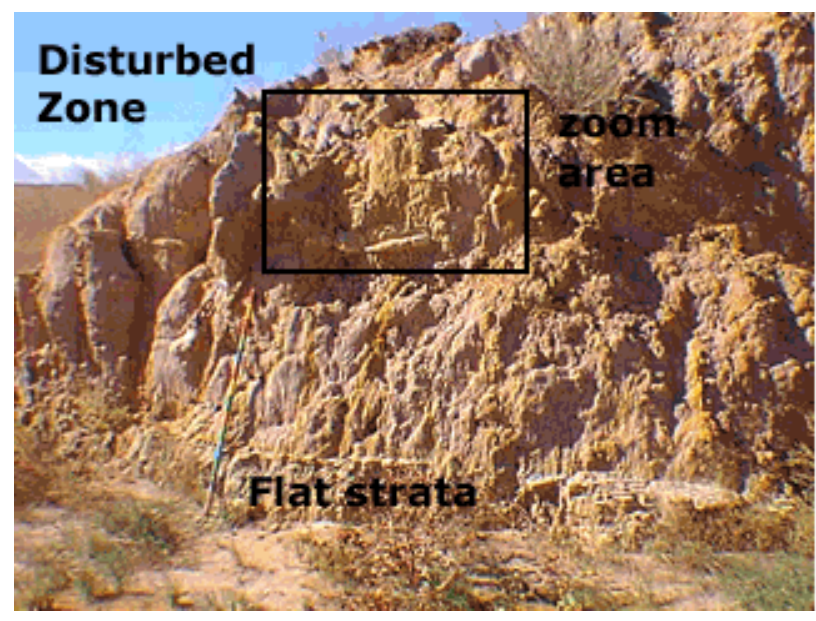

Figure 52. The DZ rests on top of flatlying strata of the upper Jeletzkeytes nebrascensis Zone of the Fox Hills Formation. The multi-colored materials of the DZ reflect the mix of shale, mudstone, and sandstone. Orange streaks are clastic dikes, glide surfaces, and dewatering structures. These do not penetrate the underlying strata. The stick is $\mathbf{1 . 5} \mathbf{~ m}$ for scale.

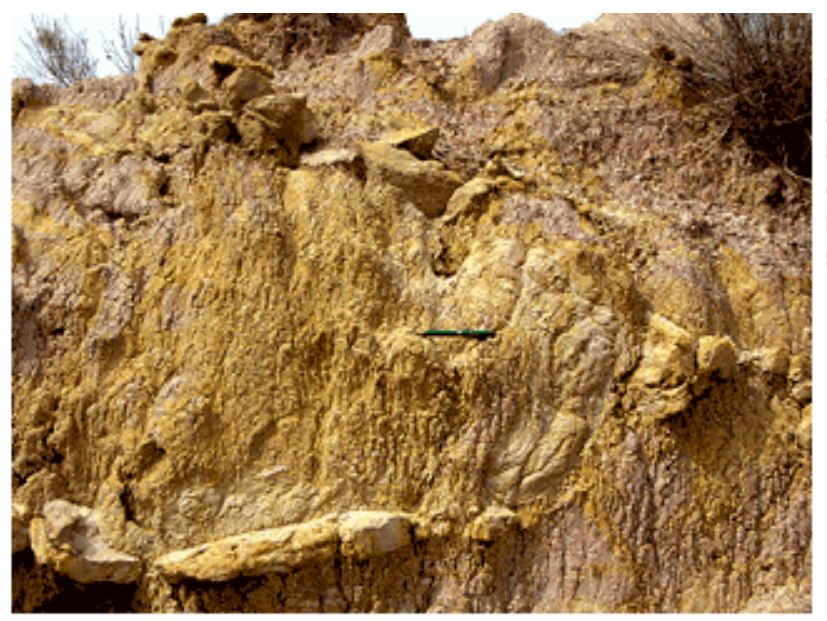

Figure 53. A close-up view of the zoom area above shows the profiles of a roll structure exposed in the cut bank. The small green pen $(15 \mathrm{~cm})$ lies in the axis of an overturned fold (roll structure). Movement was toward the south (left).
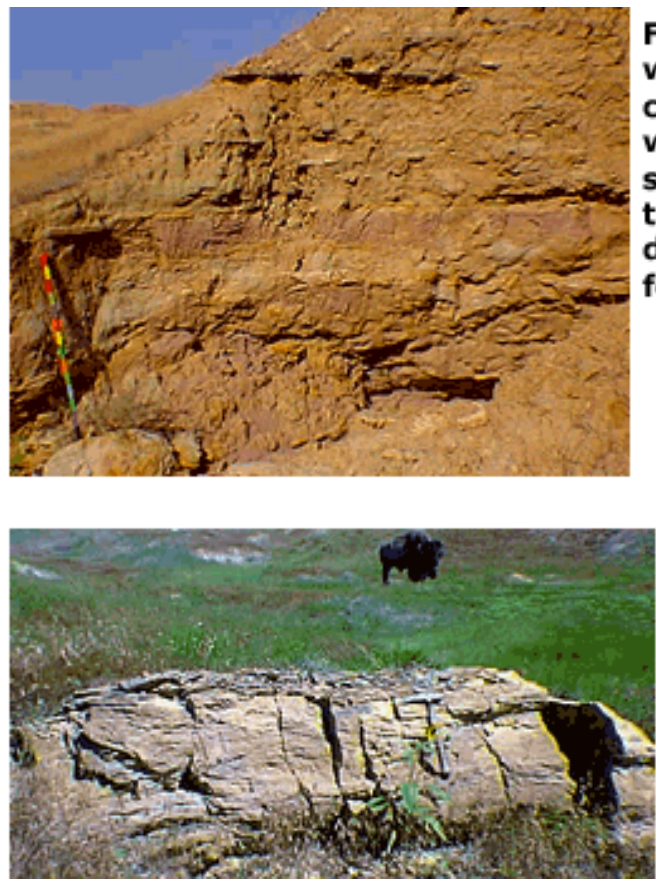

Figure 54. The pink and white beds of the DZ were planed off by erosion before the drabcolored beds of the Unnamed marine facies were deposited. The bright colors of the DZ suggest that the beds may have been exposed to subaerial weathering before marine deposition returned. The colored stick is $\mathbf{1 . 5} \mathrm{m}$ for scale.

Figure 55. A log-shaped concretion is a roll structure. Its long axis is oriented east-to-west. 


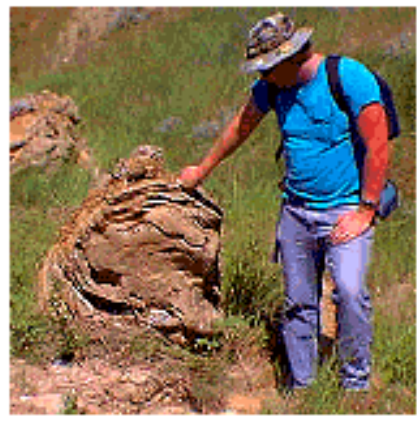

Figure 56. A cross-section view of a concretion in the DZ displays detail of the soft-sediment deformation typical of a roll structure.

\section{Wilderness Access Trailhead Locality}

The Wilderness Access trailhead locality yielded some of the most significant information about the age of the deposits (figs. 57 and 58). Specimens of Jeletzkeytes nebrascensis and other fossils were identified below the Disturbed Zone (DZ) in this location. In addition samples for paleomagnetism study and belemnite samples for isotope geochronology were gathered here (Stoffer and others, 2001). The changes in faunal content and bioturbation sedimentation patterns across the DZ in this location provide some of the strongest evidence that the DZ represents the Cretaceous-Tertiary boundary.
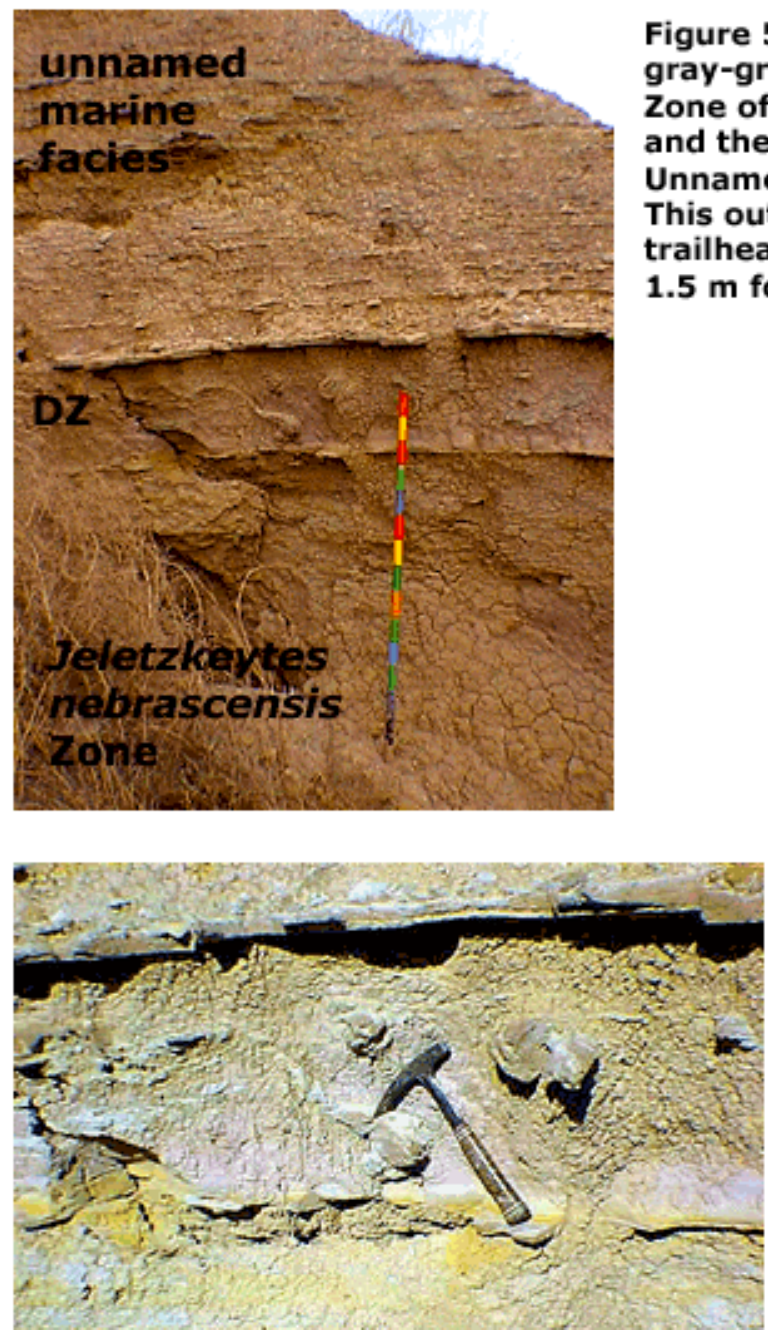

Figure 57. The DZ stands out in contrast to the gray-green marl of the Jeletzkeytes nebrascensis Zone of the lower Fox Hills Formation (below) and the alternating sand and shale beds of the Unnamed marine facies of the upper Fox Hills. This outcrop is about $\mathbf{0 . 5}$ mile southwest of the trailhead parking area. The walking stick is $1.5 \mathrm{~m}$ for scale.
Figure 58. Close-up view of soft sediment deformation features within the DZ. Sediment movement was toward the right (south). 


\section{Buffalo Gap National Grasslands Locality}

Fox Hills Formation exposures along the hilltops east of Sage about a mile north of the park boundary preserve a complete sequence encompassing the upper Pierre Shale and Fox Hills Formation that includes the Disturbed Zone. Exposures of the Fox Hills on the national grasslands suggest that sediment coloration in the Fox Hills is original and may not be associated directly with the formation of the Yellow Mounds and Interior paleosols that formed later in the Tertiary (fig. 59). East-to-west oriented roll structures demonstrate that the Disturbed Zone at this locality is similar to localities in the park (fig. 60).

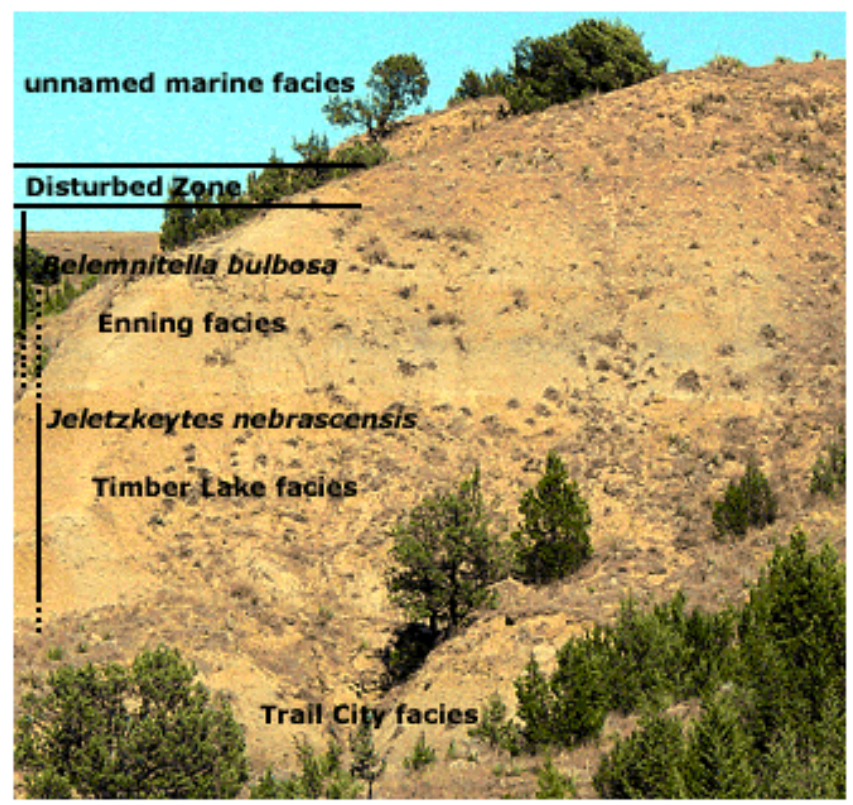

Figure 59. The different colors of units within the Fox Hills reveal that sea level fell, rose, and fell again before the $D Z$ was formed. Orangetan colored layers of the Timber Lake facies suggest that these sediments were exposed to oxidizing meteoric water prior to deposition of the Enning facies (gray). Sea level was low again when the DZ formed. The section shown here is about $\mathbf{4 0} \mathrm{m}$ high.

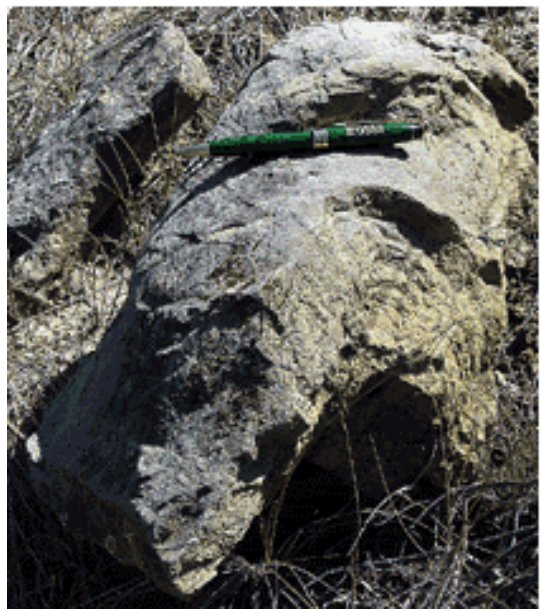

Figure 60. A roll structure from the $D Z$, the pen is $15 \mathrm{~cm}$ for scale. Roll structures throughout the outcrop belt in this area all show an east-to-west orientation with the direction of movement toward the south. 


\section{Dry Creek Locality}

The Disturbed Zone (DZ) crops out along stream level in the headwaters region of Dry Creek in the Sage Creek Wilderness Area near the park's southern boundary (fig. 61).

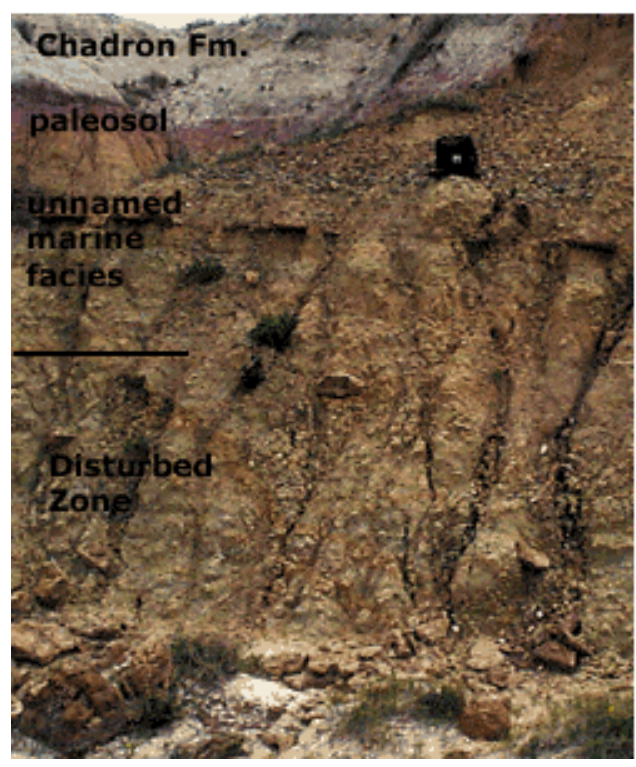

Figure 61. In the headwaters region of Dry Creek the DZ displays clastic dikes and curled bedding. As elsewhere, flat-lying, marine sediments rest unconformably on top of the DZ. However, the entire section displays heavy pedogenic alteration associated with the Yellow Mounds weathering profile (paleosol). The black backpack (for scale) rests on sandy sediments of the unnamed marine facies. Only a thin red Interior paleosol is preserved beneath the gravel bed at the base of the Chadron Formation.

\section{Unnamed marine facies (upper Fox Hills Formation)}

Sediments overlying the Disturbed Zone preserve evidence that marine conditions persisted in the region. The sediments are included in a stratigraphic interval informally named here "Unnamed marine facies of the upper Fox Hills Formation." This interval consists of flat-lying beds of shale and sandstone that locally bears an abundance of marine trace fossils, but body fossils (such as shell material and bone) are very scarce. No fossils of definitely Cretaceous species have been found in this interval above the Disturbed Zone, but fish bone fragments, teeth of a barracuda-like fish, and plant material have been observed. In the North Unit the Unnamed marine facies is thickest in the Grassy Tables Overlook locality where at least 27 individual sand sheets (with intervening shale) occur in a $14 \mathrm{~m}$ section. The sand sheet range in thickness from $1 \mathrm{~cm}$ to a maximum of about $15 \mathrm{~cm}$. Elsewhere the Unnamed marine facies are only a few meters thick at most, pinch out, or are missing along with the overlying paleosols beneath the base of the Chadron Formation. The lack of Cretaceous fossils and its location above the Disturbed Zone suggests that these sediments may have been deposited in the early Paleocene. The thickest best exposures of this interval in the park are in the Grassy Tables Overlook locality.

The sand sheets in the Unnamed marine facies preserve current-ripple bedding and in some cases, an abundance of trackways and traces. The types of trace fossils found in the upper marine facies are common in habitats ranging from the lower intertidal zone and shallow subtidal zones and can be grouped to Skolithos/Cruziana ichnofacies.

Skolithos ichnofacies typically occur in sandy sediments and is characterized by vertical dwelling burrows and tubes that extended many centimeters into a soft substrate. Cruziana ichnofacies are characterized by simple locomotion traces with some U-shaped dwelling and shallow resting and hiding traces made in soft to firm sediments (fig. 62). Both varieties of ichnofacies occur within the intertidal or shallow subtidal zone. Specific types of traces found include:

Diplacraterion are a U-shaped trace that typically display two entrance dots on the surface of a bed; 
Ophiomorphia are branching burrows with either horizontal, oblique, or vertical box-like networks; the exterior of the burrows are characterized by a "corn cob" or knobby texture formed by an shrimp-like animal that packs fecal pellet along the burrow walls;

Thalassinoides are branching burrows (Y- or T-shaped branches) with horizontal, oblique, and (or) vertical chamber-like networks and enlargements at junctions between some branches (the probable trace maker was an arthropod) (fig. 63);

Cruziana, crawling traces with a "herringbone" (chevron-like) tracks with ridges defining a medial groove; the bi-lobed character is also a result of two parallel furrows created by an arthropod's legs scratching the surface of the sediment.

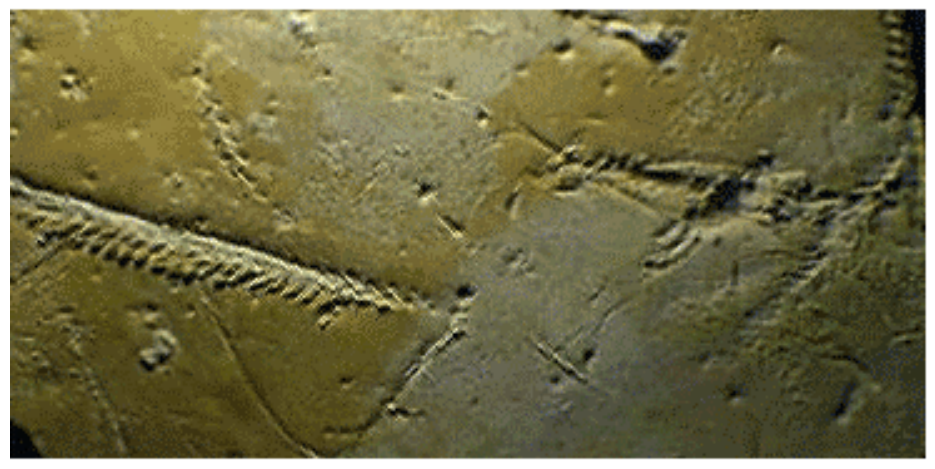

Figure 62. Cruziana (arthropod tracks, possibly sand fleas) and Diplacraterion (double holes from U-shaped worm burrows) from sand beds in the middle to upper Unnamed marine facies of the upper Fox Hills, Grassy Tables Overlook locality.

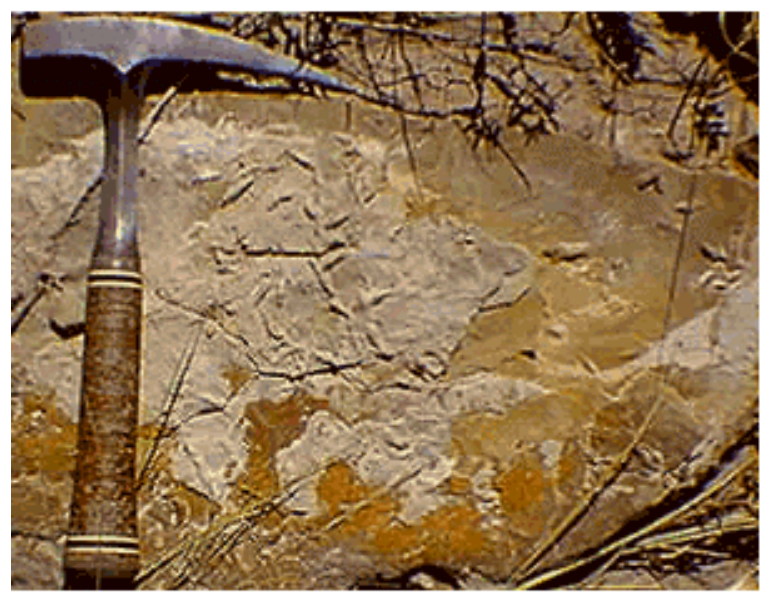

Figure 63. Thalassinoides-like traces occur in the lower part of the Unnamed marine facies of the upper Fox Hills Formation, Grassy Tables Overlook locality. The hammer handle is about $\mathbf{3 0} \mathrm{cm}$ for scale. 


\section{Tertiary Geology of Badlands National Park}

Nonmarine sedimentary rocks of Tertiary age are collectively assigned to the White River and Arikaree Groups in the Western Interior region. These strata range in age from Eocene through early Miocene, with Oligocene-age materials of the White River Group dominating the section. The White River beds consist of sandstone, tuffaceous sandstone, conglomerate, mudrocks (shale and clay mudstone), bone beds, and volcanic ash deposits deposited on an ancient floodplain that received sediments shed from uplifts throughout the Rocky Mountain region (figs. 64 and 65).

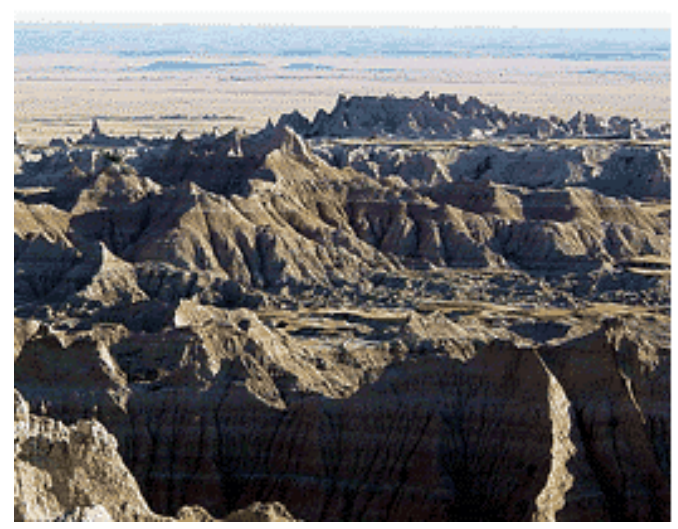

Figure 64. The scenic exposures of the White River beds, and the attraction of finding fossils they contain, are the prime reasons behind the establishment of Badlands National Park. This view is from the Badlands Loop Road (Prairie Wind Overlook) looking east toward the rugged core of the Big Badlands near the eastern end of the park.

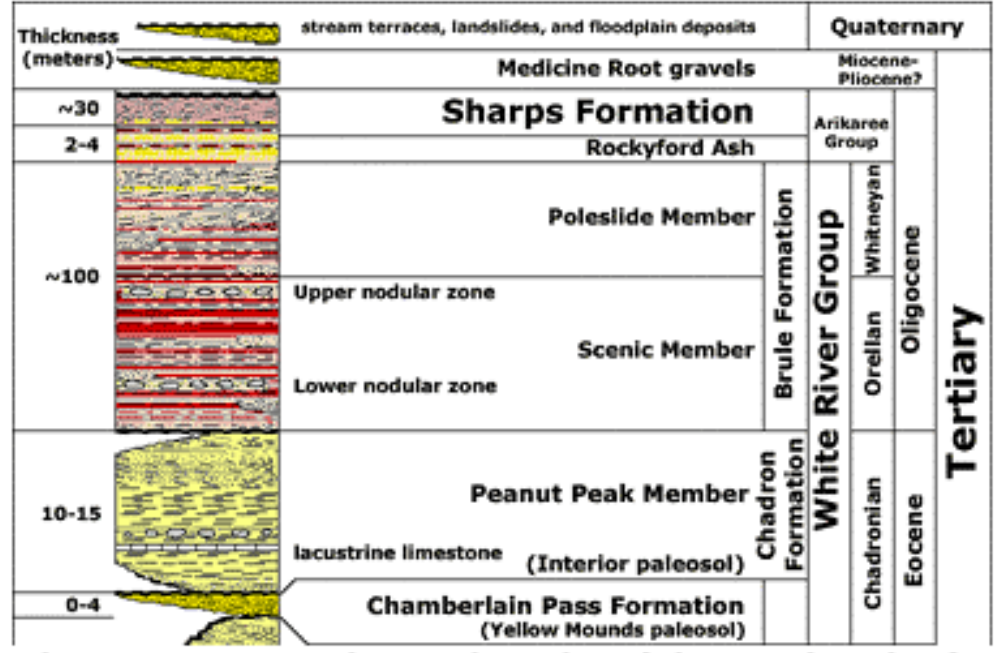

Figure 65. Cenozoic stratigraphy of the North Unit of Badlands National Park.

The different stratigraphic units of the White River beds formed under varying environmental conditions, ranging from hot, humid conditions in the early Tertiary when the elevation was still near sea level and great bodies of water (brackish inland seas and lakes) still existed throughout the Western Interior region and between the rising mountain ranges of the Rocky Mountains to the west. Through mid Tertiary, the land gradually rose and river systems evolved. Climatic condition grew progressively dryer and forested environments gave way to savannah or steppe environments. By the close of the Tertiary, desert-like conditions influenced depositional processes (particularly aeolian dust) and the fauna adapted to such conditions. 


\section{Historical Overview of the White River Group}

A search in the GeoRef database yields hundreds of citations relating to the Tertiary stratigraphy of the Western Interior region. This discussion only touches on the naming of specific stratigraphic units (summarized by Agnew and Tychsen, 1965), but makes no attempt to review the rich body of knowledge gained from the study of the Tertiary deposits in the Badlands region.

F.B. Meek and F.V. Hayden first published on the name "White River" for deposits in the Nebraska Territory in 1858. They mention that the oldest member of the sequence is a Titanotherium bed (now Chadron Formation). Meek and Hayden (1862) recognized that the White River beds were not marine or brackish marine deposits and that in Wyoming the White River beds overlie Fort Union and Lance beds (Paleocene) and underlie Loup Fork beds (Pliocene beds). Meek (1876) locally subdivided the White River into the Chadron Formation (below) and the Brule Formation (above). J.L. Wortman (1893) applied the named "Oreodon beds" (lower) and "Protoceras beds" (upper) to be later named the Brule Formation by Darton (1899).

Further subdivisions of the formations were made over time. John Clark (1954) subdivided the Chadron Formation into three members: Ahearn (lowest), Crazy Johnson (middle), and Peanut Peak (highest). All three members occur in the vicinity of the park's South Unit, but only the Peanut Peak Member is recognized in the North Unit.

J.D. Bump (1954) subdivided the Brule Formation into two members: Scenic Member (lower - formerly "Oreodon beds") and Poleslide Member (upper - formerly "Protoceras beds"). J.R. McDonald recognized that "Miocene-age" strata (Rosebud Formation) overlies the Brule Member and is equivalent in age to Arikaree Group elsewhere in the region. In the park area, Arikaree age sediments of latest Oligocene age were recognized and assigned the name Sharps Formation (Harksen and others, 1961). Nicknish and Macdonald (1962) assigned the name Rockyford Ash to a thick widespread volcanic ash deposit that defines the base of the Sharps Formation.

Retallack established a type section for the White River and lower Arikaree Groups in Badlands National Park in the Pinnacles area of the North Unit (in the headwaters region of Conata Creek). In this section he recognized as many as 87 superimposed fossil soils in $143 \mathrm{~m}$ of stratigraphic section, including up to 10 different types of fossil soils in addition to stream channel deposits. Terry and Evans (1994) also recognized an Eocene channel and floodplain deposit that is older than the base of the Ahearn Member of the Chadron, but younger than the Yellow Mounds weathering profile on older marine mudrocks below the White River Group.

\section{The Yellow Mounds and Interior Paleosols}

The base of the White River Group rests unconformably on a surface that locally preserves ancient weathering profiles. At least two weathering profiles of different ages are now recognized beneath the Chadron Formation (fig. 66). The older surface, the Yellow Mounds weathering profile, was recognized by Pettijohn (1965) to be a regional weathering surface of Eocene age that formed on an eroded surface of older formation ranging in age from Late Cretaceous to Eocene. In the Badlands National Park region, the Yellow Mounds is imprinted on Fox Hills Formation in the north and east and on Pierre Shale closer to the Black Hills. 


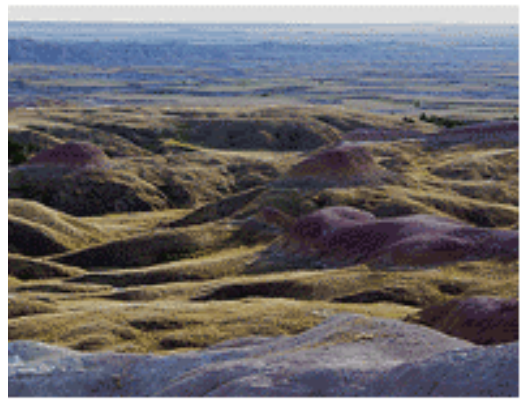

Figure 66. Brightly colored low hills in the

Grassy Tables Overlook area in the North

Unit of Badlands National Park consist of

the combined Yellow Mounds and Interior paleosols (described by Retallack, 1983).

Retallack (1983) supported the idea that the Yellow Mounds represent a paleosol, or series of paleosols, of Eocene age. He suggested that the yellow coloration of the Yellow Mounds was a result of meteoric weathering of older marine sediments exposed near the surface over a long period of time. In some places (such as shown below in fig. 67) the orange-colored sediments of the Yellow Mounds preserve crossstratification (probably stream-channel deposits).

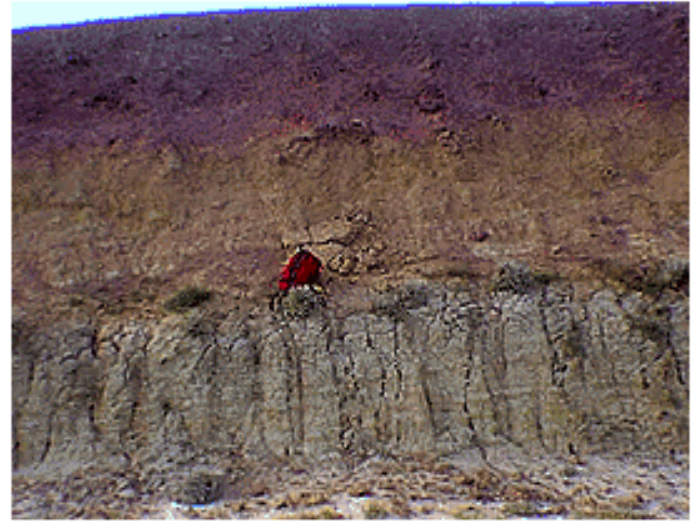

Figure 67. A cut bank along a tributary of Sage Creek in the Grassy Tables Overlook area demonstrates unconformable relations between each of four colored lithologies (bottom to top, green, orange, red, and gray). The green beds are marine beds of the upper Fox Hills Formation (Paleocene?). The orange beds locally preserve cross bedding associated with migrating stream channel deposits; these deposits are associated with the Yellow Mounds paleosol; the red interval consists of flood plain deposits associated with the Chamberlain Pass Formation, but display pedogenic alteration in association with the Interior paleosol.). The thin gray cap is basal Chadron Formation (without gravel in this location).

The distinct coloration of the sediments of these four units (shown in fig. 67) reflects the differing depositional environments in which they formed. The green beds are unaltered shallow marine sediments (bearing trace fossils). The orange "Yellow Mounds" consist of soils and (or) reworked soil, possibly associated with mixed brackish and freshwater environments. The red "Interior Paleosol" soil reflects higher oxygenating conditions. This is supported by an abundance of fossil termite nests and other burrow that occur locally throughout the Grassy Tables Overlook exposure belt. Terry and Evans (1994) include these floodplain-style deposits in the Chamberlain Pass Formation.

The red earth of the "Interior-Chamberlain Pass" interval stands out in contrast to the gray floodplain sediments of the overlying Chadron Formation. In the past, the inferred thickness of the "Yellow Mounds" have supported the idea that a great period of time lapsed between erosion and exposure of the older Cretaceous sediments and deposition of the basal Chadron Formation. A new interpretation presented here is that sedimentation was more continuous, albeit slow, between the times when the Western Interior Seaway (or Cannonball Seaway) finally withdrew and when sediments derived from the exposure of the core of Laramide mountain ranges began to flood across the Badlands region. Just as changes in eustatic sea level affected depositional patterns in the sediments of the Western Interior Seaway, global eustatic cycles probably also influenced the pattern of stream base level (and consequent deposition and erosion) on the early Tertiary landscape. Backfilling of stream valleys occurred during high stands in sea level, and soil-weathering profiles formed when stream base level fell (associated with a fall in sea level). The pattern of coloration typical of the terrestrial deposits of the White River Group did not come into play possibly 
until the landscape had finally risen high enough to not be directly linked or influence by global changes in sea level.

\section{Chamberlain Pass Formation}

Terry and Evans (1994) gave the name Chamberlain Pass Formation to beds that crop out along an unconformable surface between the weathered Pierre Shale (Yellow Mounds) and beneath the base of the Chadron Formation (fig. 68). The upper surface of the Chamberlain Pass has a red paleosol overprint (the Interior paleosol). It is therefore younger than the Yellow Mounds paleosol, but older than the Interior paleosol (after Retallack, 1983). Terry and Evans (1994) recovered a fossil tooth from the gravel and established that the age of the deposit was Eocene.

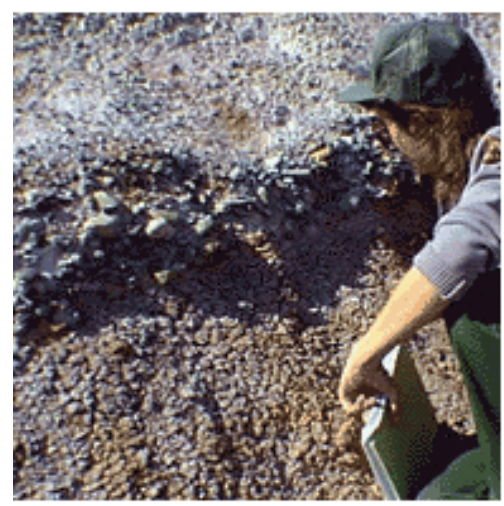

Figure 68. A conglomeratic bed of the Chamberlain Pass Formation caps a butte of in the Yellow Mounds west of Interior (outside of the park). Within the Sage Creek Wilderness Area in the North Unit, the Chamberlain Pass Formation consists of flood plain deposits (lacking gravel) and is essentially indistinguishable from the Interior paleosol. Conglomerate in the Chamberlain Pass is older than the conglomerate in the base of the Peanut Peak Member of the Chadron in the Sage Creek Wilderness Area.

\section{Chadron Formation}

In Badlands National park poorly consolidated mudrocks of late Eocene age are assigned to the Chadron Formation (fig. 69). The formation is named after the town of Chadron, Nebraska where strata equivalent in age and character crop out. The interval was originally named the Titanotherium beds after an abundance of bones of large rhinoceros-like mammals were observed and mapped by early investigators. Of the three members of the Chadron Formation only the Peanut Peak Member (the youngest member) is recognized in the North Unit of Badlands National Park. Portions of the two older members, the Ahearn Member (oldest) and Crazy Johnson Member (middle) are preserved in the South Unit region with equivalent strata in northwestern Nebraska (Terry, 1998).

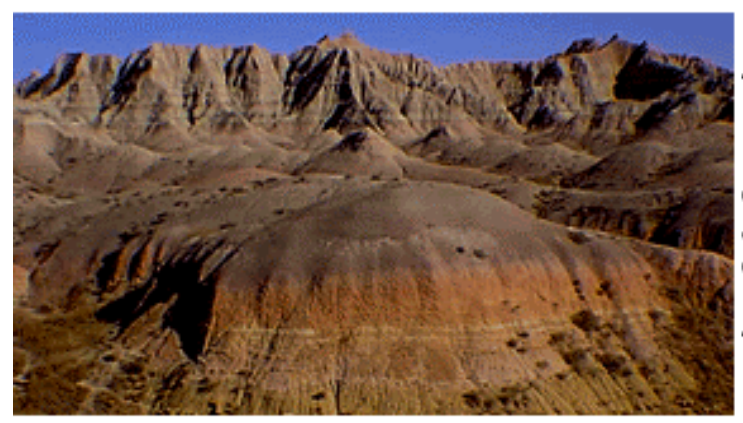

Figure 69. In the North Unit, the Chadron typically forms a bench-like surface with rolling, incised topography (locally forming "haystack mound"-like hills) between the colorful beds of the "Interior zone" below and the steep, banded (gray and red) beds of the overlying Brule Formation. This view is from the Rainbow Colors Overlook along the Badlands Loop Road near Dillon Pass.

The Chadron consists of typically gray to olive-gray sandy clay, but locally preserves conglomerate at its base and also preserves white, freshwater limestone lenses, a short distance above the base. The high bentonitic-clay content turns the weathered surfaces of the Chadron to a slick gumbo when wet that dries to a frothy popcorn textures. These characteristics create an inhospitable environment for most vegetation, and so the Chadron is typically barren throughout it outcrop exposure belt. 
Intermittent lenses of coarse gravel (poorly consolidated conglomerate) crop out at along the base of the Chadron Formation (fig. 70). The gravel and sand in the formation consist of chert, granitic rocks, and metamorphic materials probably derived from streams draining the core and surrounding sedimentary outcrop belts of the Black Hills region and possibly from more distant sources. Some of the chert cobbles preserve structures typical of conical algal stromatolites, and are probably Cambrian or Precambrian in age. The source of these chert cobbles is unknown.

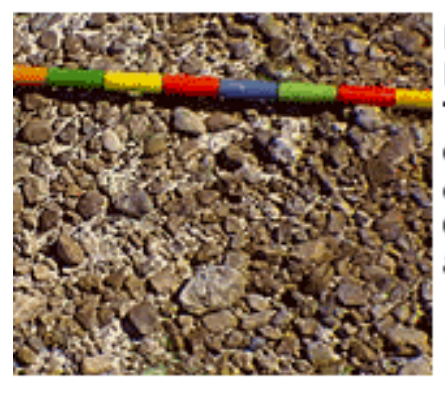

\begin{abstract}
Figure 70. Conglomerate derived from the basal Chadron Formation forms a "desert pavement" in many places. This example is in the southern Sage Creek/Dry Creek drainage region in the North Unit. Pavement like this can cover many acres in areas of low relief and are a relict of Quaternary stream terrace development. Chadron gravels are rich in chert.
\end{abstract}

Freshwater limestone beds (bearing fish and plant remains) occur intermittently in the lower part of the Chadron Formation in the North Unit. This limestone forms a cap rock on many buttes throughout the Sage Creek Wilderness Area, including White Butte just east of the Sage Creek Campground (fig. 71). The upper part of the formation consists mostly of a sandy clay mud that weathers to a popcorn gumbo mud.

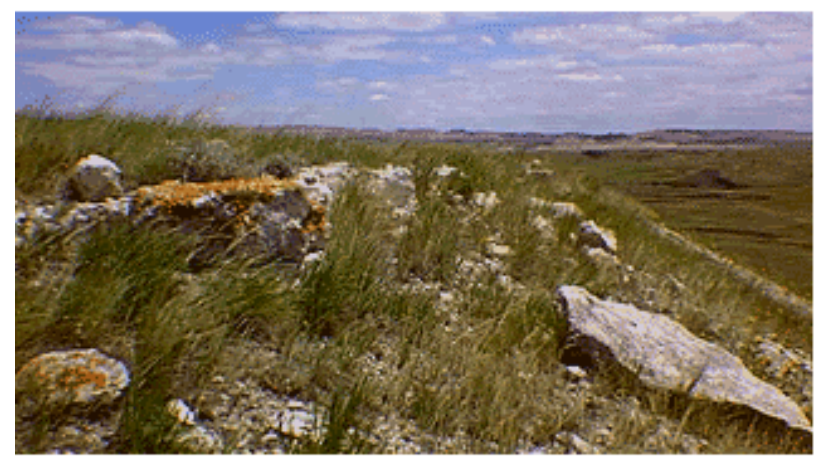

Figure 71. A freshwater limestone layer in the lower Chadron Formation forms the resistant cap rock of White Butte in the Sage Creek Wilderness Area. Several other buttes in the Sage Creek Wilderness Area are capped with the same white limestone layer.

The Chadron Formation was originally named the "Titanotherium beds" and was originally assigned to the Oligocene Epoch. However, with additional regional correlation and discovery, the Chadron interval is now recognized as being latest Eocene in age, with the name "Chadronian" assigned to the last stage of the epoch (Terry, D.O., Jr., 1998). Radiometric dates from ash deposits recovered from the lower Chadron (Ahearn Member) provided and age of $37.2(+/-.7)$ million years (Retallack, 1983). Deposition associated with the Chadron is regarded as being basically "continuous" with the overlying Scenic Member of the Brule (of early Oligocene).

Scientific investigations of fossils and sedimentary deposits have yielded information to support interpretation of how the landscape may have appeared at the time the materials were deposited. In addition to bones, the sediments preserve traces of invertebrate remains, plant materials, root traces, animal burrows, coprolites, animal tracks, fossil soils, and sedimentary deposits typical stream and floodplain deposits (including shallow, warm lakes). The deposits also preserve evidence of the chemical processes associated with converting the soft sediments and organic remains to rock, a complex variety of processes collectively called diagenesis. Understanding depositional environments and diagenetic processes is important to understanding why fossils may be preserved in one location, but not another. Retallack (1983) provided an overview of the variety of fossils recovered over time from the Chadron Formation and overlying Scenic Member of the Brule. His list includes: 


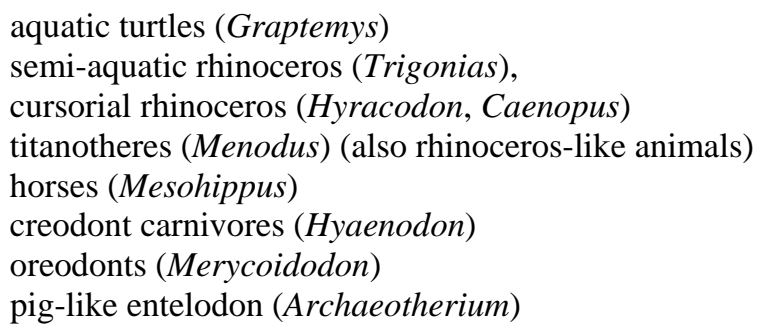

Other fossil remains discovered include: alligator, frog, lizard, birds, opossum, small insectivore, rodent, saber-tooth cat, tapiroid, peccary, camel, and squirrel-like, deer-like, rabbit-like and fox-like animals, and others. This community of species is consistent with a forested floodplain with scattered sedge meadows, oxbow ponds, and forested upland environments. By Oligocene time, the forested uplands gave way to dryer savannah-like environments.

\section{Brule Formation}

The Brule Formation represents stream and floodplain deposit that accumulated during Oligocene Epoch (between about 32 and 26 million years ago). The Brule is subdivided into two members. The lower Scenic Member conformably overlies the gray mudrock of the Chadron Formation and consists of alternating rusty-red and grayish white layers of strata. The upper Poleslide Member is dominated by light gray massive cliff-forming sandstone (with fewer red layers). The Poleslide Member is overlain by the more tuffaceous sandstone and mudrocks of the Sharps Formation (fig. 72).

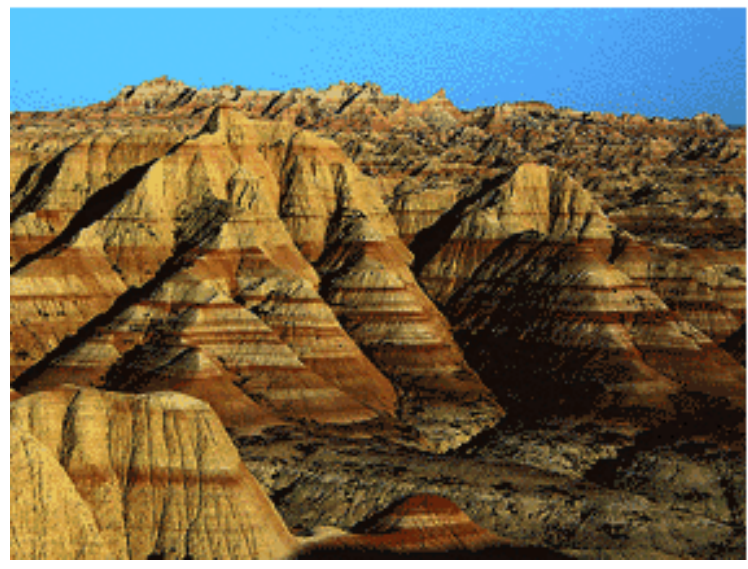

Figure 72. An east-facing view of the Big Badlands from the Prairie Wind Overlook along the Badlands Loop Road. The Scenic Member begins at the break in slope (above the gray Chadron beds). The Poleslide begins at the cliffy transition from rusty-red slope to steeper, more rugged slope and cliffs of white- to tancolored sandstone and mudrock. The Sharps Formation makes up the only the highest peaks in the Big Badlands.

The Scenic Member consists of a series of ancient soil profiles (paleosols) that developed on a broad, aggrading floodplain. The white layers represent stream channel bar and over-bank splay flood sand deposits. The rusty-red layers represent paleosols that developed slowly on broad floodplain surfaces. Individual layers of floodplain soil (red) and the sand sheets (white) consist of over-bank, channel bars, and natural levy deposits. Some beds can be traced for hundreds, even thousands of meters along outcrops. The broad extent of individual beds in the Scenic Member suggest that low relief in the region allowed ancient stream channels to gradually migrated back and forth across a broad savannah-like floodplain.

The Poleslide Member represents a change to larger stream channels that developed as conditions became increasingly drier in the mid to late Oligocene. Continuous streams became more ephemeral, and depositional patterns in the rock reflect more episodic flood events than deposition by perennial streams. Water holes became more important sites for survival of species adapted to open plain environments over forests. The Meek and Hayden Survey in the late 1850s originally described the Brule Member as the "turtle and oreodon beds." Remains of land turtles and oreodons (sheep-like animals that dug burrows) are 
common in some layers in some areas (fig. 73). Oreodons (a variety named Merycoidodon) and turtles beds are part of the lower Scenic Member. Channel sand deposits in the upper Scenic Member were originally called the "Metamynodon beds" named after bone beds containing an aquatic variety of rhinoceros. The Poleslide Member preserves bone beds of a horned sheep-sized herbivore, Proteroceras, and also contains oreodons (a variety named Leptauchenia).
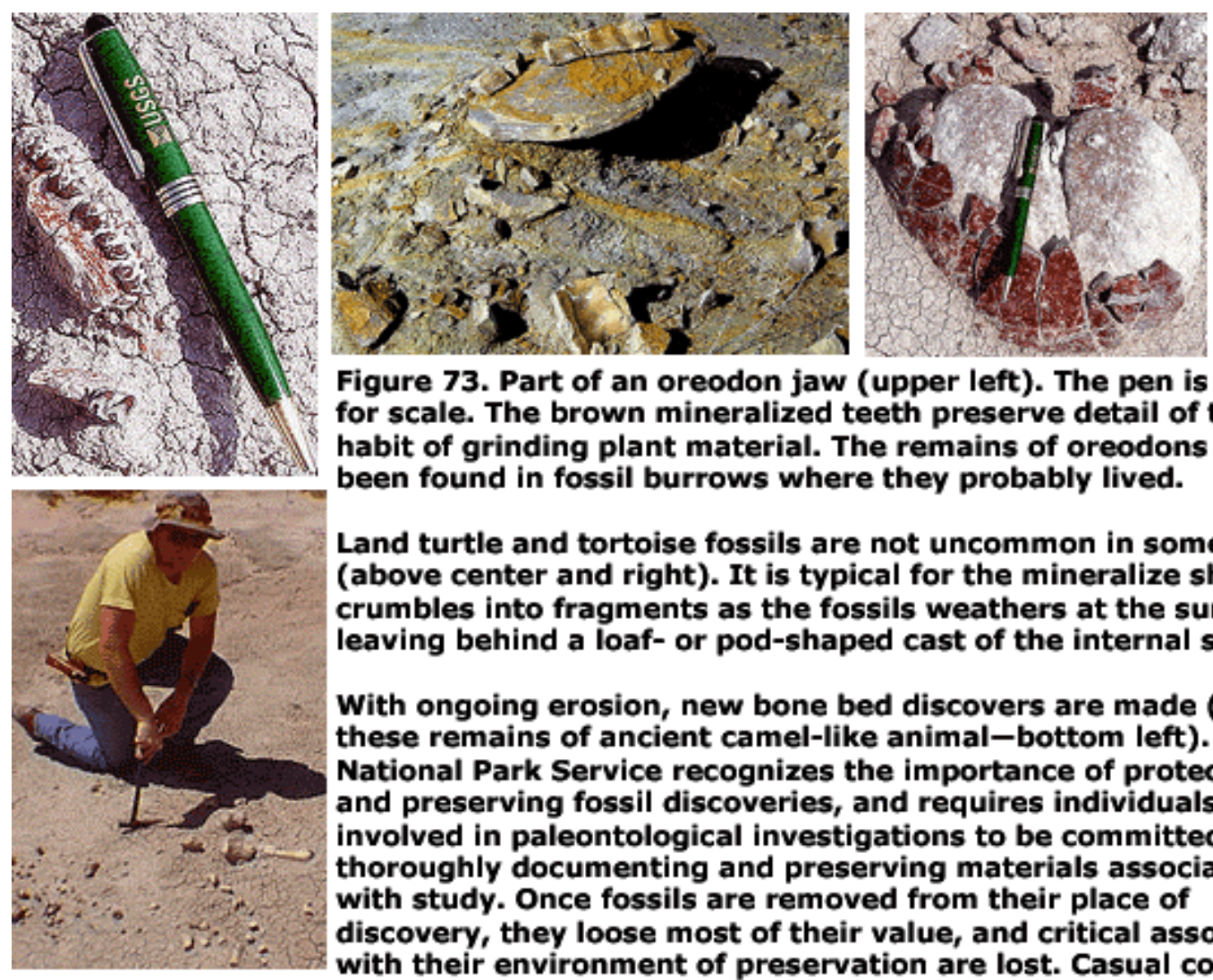

Figure 73. Part of an oreodon jaw (upper left). The pen is $15 \mathrm{~cm}$ for scale. The brown mineralized teeth preserve detail of the life habit of grinding plant material. The remains of oreodons have been found in fossil burrows where they probably lived.

Land turtle and tortoise fossils are not uncommon in some beds (above center and right). It is typical for the mineralize shell to crumbles into fragments as the fossils weathers at the surface, leaving behind a loaf- or pod-shaped cast of the internal shell.

With ongoing erosion, new bone bed discovers are made (such as these remains of ancient camel-like animal-bottom left). The National Park Service recognizes the importance of protecting and preserving fossil discoveries, and requires individuals involved in paleontological investigations to be committed to thoroughly documenting and preserving materials associated with study. Once fossils are removed from their place of discovery, they loose most of their value, and critical associations with their environment of preservation are lost. Casual collecting and theft of fossils from investigation sites have been a serious problem over time and is a prime reason why the Badlands are now a national park.

\section{The Pig Dig Site}

An example of a fossil discovery happened in the late 1990's when a park road crew working along Conata Road recognized bones in a ditch they were digging (fig. 74). The site has been thoroughly investigated and has given the public an opportunity to watch paleontologists conducting the arduous, time-consuming task of carefully excavating and preparing fragile fossils for a move to the park's museum collection.

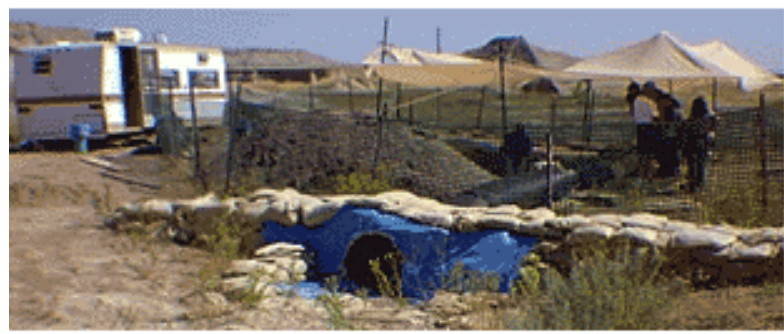

Figure 74. The "pig dig" is an example of a rich bone bed in the lower Brule Formation found in association with a "fossil watering hole." The site has yielded a variety of specimens including Subhyracodon, Archaeothrium, Mesohippus, and Leptomeryx (from a NPS brochure about the Pig Dig site). 


\section{Sharps Formation}

The Sharps Formation reflects an overall change in geologic and environmental conditions that began 26 to 28 million years ago. The region became even drier, and mammoth ash fall deposits associated with tremendous ignimbrite-style volcanic eruptions in the Great Basin region episodically blanketed the Badland region. The Sharps consists mostly of tuffaceous sandstones, stream channel sand and floodplain mud (paleosols) typical of steppe or even desert-like conditions. Harksen and others (1961) who first described the formation thought its age was Miocene. The Sharps Formation is now recognized to be latest Oligocene but is assigned to the Arikaree Group (a group dominated by Miocene-age rocks elsewhere in the region).

The highest peaks in the badlands consist of the eroded remnants of Sharp Formation (fig. 75). More complete exposures of the Sharps Formation can be seen at Agate Fossil Beds National Park in northwestern Nebraska (about 200 miles southwest of Badlands National Park). The Sharps Formation marks the end of floodplain-style deposition preserved in the park region. If younger Tertiary deposits existed in the region they were stripped away by erosion. At the close of the Tertiary Period erosion was the dominating force in the region. Down-cutting streams began to exhume the Oligocene strata. On some of the highest tableland in the park area are gravel deposits consisting of materials carried by fast-moving streams flowing away from the Black Hills. These deposits, called the Medicine Root Gravels, are about 2 million years old and were deposited prior to or near the beginning of the ice ages of the Quaternary period. Much of the Badlands landscape is a reflection of the erosional history of the region over the past two million years.

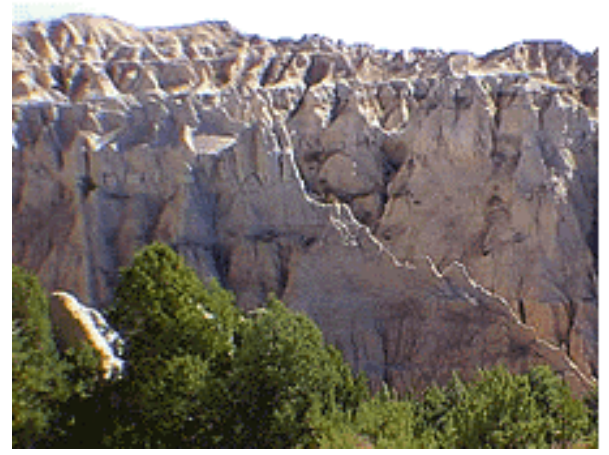

Figure 75. The Rockyford Ash defines the base of the Sharps Formation. The ash bed forms a white, massive resistant, ledge-forming cap rock, as shown here at the Pinnacles Overlook area. Numerous clastic dikes crosscut the upper Scenic Member of the Brule Formation and Sharps Formation. A clastic dike forms the ridge descending to the right in this image.

\section{The Quaternary Landscape}

The modern landscape in the Badlands National Park region is largely a reflection of ongoing erosional processes over the past several million years. In the late Tertiary the process of regional aggradation (building up of sedimentary depositions across a flat landscape) gave way to regional degradation (overall down cutting of streams into their valleys). The youngest Tertiary-age sedimentary deposit in Badlands National Park are a thin blanket of Medicine Root gravels cap the highest upland areas in the Pinnacles Overlook area. These gravels are stream terrace deposits deposited probably in latest Miocene or early Pliocene time. These gravels were probably originally derived from fast-flowing streams draining the core of the Black Hills. These deposits also have a blanket of aeolian dust deposits that gradually accumulated during episodic periods of massive dust migration during dryer periods of the Pleistocene. Where preserved, these surficial dust deposits have since been converted to soil through weathering processes. 


\section{Three Rivers Over Time}

The Badlands lies within the headwaters region of three rivers, the Cheyenne, White, and Bad Rivers (figs. 76 and 77). Through time, these three river systems have gradually carved into the plateau that makes up the Badlands region (a plateau being an elevated region typically underlain by flat-lying sedimentary rocks). As a result of stream capture and erosion, mesa and pinnacles of rock are left behind as erosion gradually carves back the bounding escarpments or "walls" of this plateau. For instance, the town of Wall is named for the east-facing escarpment on the north side of the park that faces the headwater region of the Bad River.

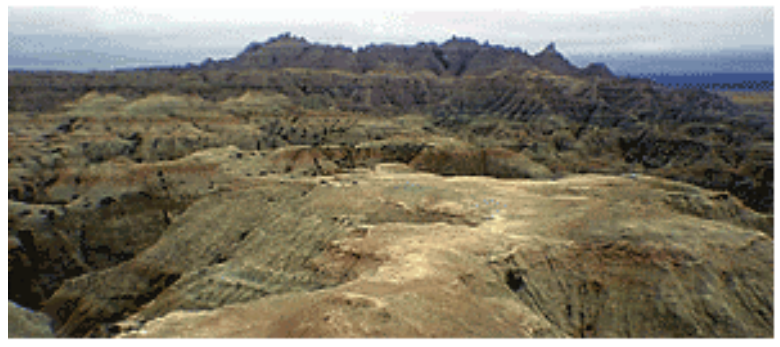

Figure 76. Gravels amongst the highest peaks of the Badlands indicate that streams drained over the region several million years ago, and that the land is gradually wearing away year by year. This view is of the Big Badlands and Badlands escarpment facing the White River valley (to the right).

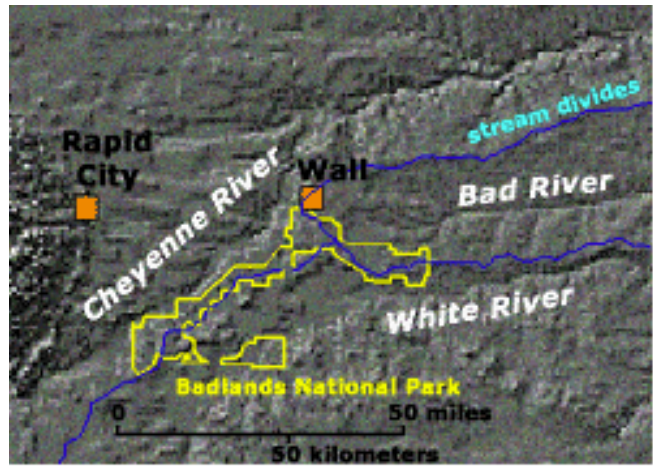

Figure 77. The divides of three river basins converge in the vicinity of the High Pinnacles in the North Unit of Badlands National Park.

Although the Badlands region was not directly impacted by continental glaciation, the continental glaciers are partly responsible for the ongoing landscape development because of their influence on regional river systems. Before the ice ages began in the late Tertiary river systems probably drained northward from the Western Interior region into the Hudson Bay region. As the larger continental ice sheets formed these north flowing rivers were blocked by the advancing glacial ice and large lakes formed along the ice front (perhaps much larger in area and volume than the modern Great Lakes). Eventually the flooded valleys filled to capacity and water flowed over divides into the next lower valley. In this manner the modern river systems evolved with the Missouri and Ohio Rivers merging with the Mississippi River system. The Missouri River basically follows the southwestern boundary of the last major glaciation.

The original rivers that drained northward into the Hudson Bay region probably had a more gentle stream gradient than that of the Missouri River when it formed along the southern ice front. As a result, over time the Missouri River has carved a gorge about 100m deep for most of its length across the Western Interior region. This down cutting of the main drainage has been gradually translating upstream into the headwaters of all its tributaries, producing the relief we currently see in the Badlands region. The rate of down cutting by rivers has not been equal across the region. The Cheyenne River has captured all the major streams draining from the Black Hills region, stealing water that probably once flowed into the White River and other streams. Throughout the western park region are many low divides between the White River and Cheyenne River valleys. These dry, low divides are an indication that stream capture has occurred. For instance, much of the area that is currently drained by Sage Creek probably drained to the south into the 
White River before stream capture occurred. On the low plateau between South Fork and Dry Creek in the southern end of Sage Creek valley are a series of old meandering stream channels left high and abandoned after stream capture changed the direction of drainage northward into the modern Sage Creek valley.

\section{Stream Terraces: Can They Tell Us About Past Climatic Conditions?}

Bench-like terraces made up of stream gravels are a fairly common occurrence along the sides of stream valleys throughout the Western Interior region. For instance, well-developed stream terraces can be seen along Rapid Creek valley between Scenic and Rapid City. Eliot Blackwelder (1915) recognized these terraces (or surfaces) throughout the central Rocky Mountains region and correlated them with major glaciation cycles (Blackwelder demonstrated that glacial moraines rest on well-developed terrace deposits along major stream drainages and grow progressively older going up section on the valley sides). Many glaciation periods occurred through the course of the ice ages, but four major glaciation periods are recognized in the mid-continent region. These major glaciation periods (stages) and interglacial warming periods (stades) are interpreted as follows (youngest to oldest; names shown include mid-continent continental glaciation cycles, International Quaternary stage numbers (IQ), and central Rocky Mountain glaciation cycles and interglacial "erosion cycles" of Blackwelder, 1915):

\section{Quaternary and Late Tertiary Time Scale (Stages and Stades)}

Holocene Epoch: (International Quaternary [IQ] stade 1): the current post-glacial warm period (stade) beginning roughly 11,000 years ago to the present. The current rise in global sea level following the last glaciation cycle is called the Flandrian transgression.

\section{Subdivisions of the Late Pleistocene Epoch:}

Wisconsin glaciation (IQ stages 2 and 4): consists of a series of glacial advances and retreats 100,000 to 11,000 years ago (called Pinedale glaciation stage in the central Rocky Mountains);

Sangamon interglaciation (IQ stade 5): a mostly warm period between 100,000 to 250,000 years ago) (associated with the Lenore erosion cycle in the central Rocky Mountains);

Illinoian glaciation (IQ stage 6): - consists of a series of glacial advances and retreats 400,000 to 250,000 years ago (called Bull Lake glaciation stage in the central Rocky Mountains);

Yarmouth interglaciation (IQ stade 7): a mostly warm period between the Illinoian and Kansan stages (associated with the Circle erosion cycle in the central Rocky Mountains).

\section{Subdivisions of the Early Pleistocene Epoch:}

Kansan Stage (IQ stage 8+) - consisted of a series of glacial advances and retreats 900,000 to 750,000 years ago (associated with the Buffalo glaciation stage in the central Rocky Mountains);

Aftonian Stade (IQ stade 11+?) - a mostly warm period between the Kansan and Nebraskan stages (associated with the Black Rock and(or) Union Pass erosion cycles in the central Rocky Mountains);

Nebraskan Stage (IQ stage 14+?) - consisted of a series of glacial advances and retreats between 2 million and 1.65 million years ago. 


\section{Pliocene Epoch and Late Miocene Epochs:}

Early glaciation periods may have occurred in the region prior to 1.65 million years, but no evidence has clearly established in the Western Interior region. The Fremont surface (also called "Summit peneplain") in the central Rocky Mountains may represent remnants of a late Miocene to early Pliocene pediment surface.

The correlation between climatic conditions between glaciation and interglaciations period to surficial processes is a complex, unending debate. Because glacial deposits rested on stream terraces in the Wyoming region, Blackwelder (1915) correlated the "wetter" glaciation periods with periods of floodplain broadening. He also interpreted that during the "dryer" interglacial periods streams carved into their floodplains. These periods of stream down cutting left remnants of the old floodplains abandoned as stream terraces along the sides of stream valleys draining uplifts in the Rocky Mountain region. Valley widening versus down cutting is related to sediment-transport capacity of streams. And, valley widening occurs when the valley floor is protected from erosion (during periods of high sediment supply). Down cutting (and terrace formation) results when the sediment-transport capacity changes so that stream channel erosion proceeds faster than the influx of sediment from upstream sources. However, the response of a stream to climatic changes may differ over a range of hundreds or thousands of years (Hancock and Anderson, 2002). As a result of time averaging, only the major "cycles" will produce long-lasting surficial features that can be seen today, and the origin of landscape features (such as escarpments or terraces) may be more related to past upstream stream-capture events than climatic cycles.

In the Badlands region terraces are apparent along some stream drainages, perhaps most notably along Rapid Creek between Scenic and Rapid City. Within Badlands National Park, the broad valley of Sage Creek is filled with Late Pleistocene sediments (fig. 78). The modern stream channel of Sage Creek is currently incised into this flood plain by about 10 meters. This crosscutting relationship suggests the previous valley broadening (flood plain development) occurred during the Wisconsin glaciation cycle, but specific climate and erosion (and deposition) relationships are unclear.

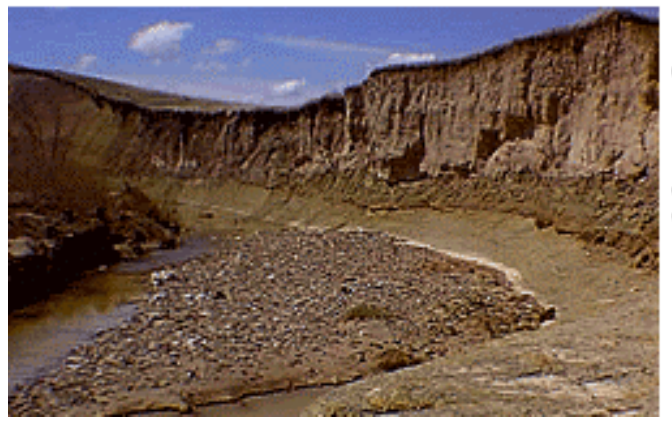

Figure 78. The modern channel of Sage Creek exposes Late Pleistocene floodplain sediments (light gray) filling an older incised valley cut into Cretaceous sediments. Studies of fossils and sediment content of such deposits may yield information about how climatic changes influenced floodplain development in the past.

Higher "surfaces" in the Badlands suggest earlier cycles of floodplain development followed by stream down cutting. Throughout the southern Sage Creek Wilderness Area much of the landscape is an erosionally dissected surface. Areas that hint of older valleys (erosional surfaces) can be seen on an enhanced digital elevation model (fig. 79). 


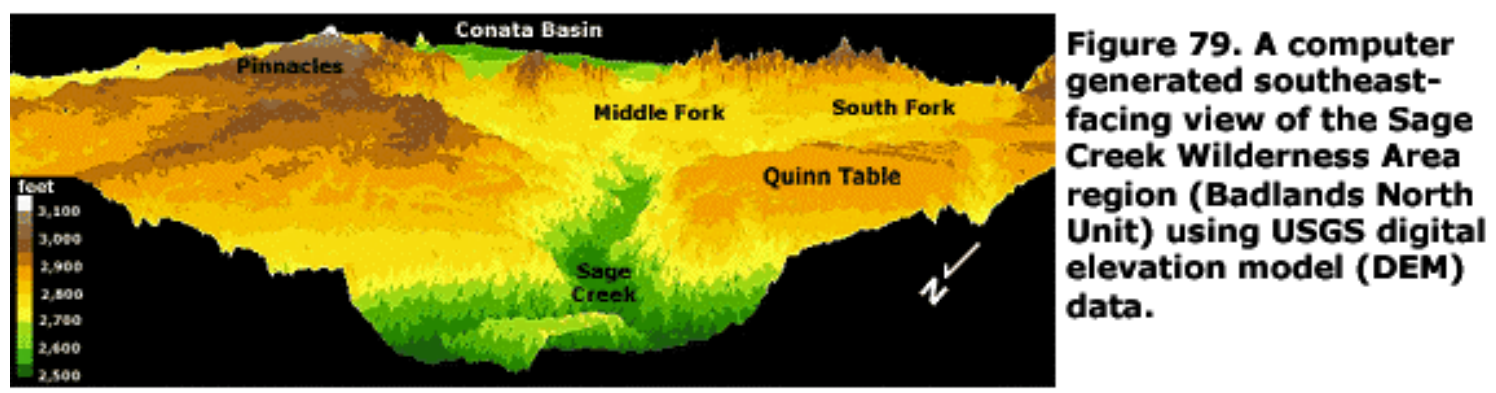

Eroded surfaces occur in different elevation ranges in different areas. From lowest to highest are:

Sage Creek - The broad valley of Sage Creek in the vicinity of the campground is an elevated floodplain about $10 \mathrm{~m}$ (30 feet) above current stream level. This surface probably also corresponds to a similar elevated floodplain surface throughout the Conata Creek drainage basin region (south of the Badlands escarpment). Possible association: Pinedale Stage.

South Fork - A low upland region forms a low dissected plateau that is perhaps best developed in the region between South Fork and Middle Fork (of Sage Creek) and their tributaries. This plateau is in the range of 30-40 m (100-120 feet) above modern stream level. Possible association: Bull Lake Stage.

Quinn Table - The broad flat surface of Quinn Table defines a higher erosional surface in the range of 110-120 m (350 to 400 feet) above stream level. Possible association: Buffalo Stage.

Pinnacles - The highest surface in the Badlands region is associated with the late Medicine Root Gravels. The High Pinnacles in the North Unit and the plateau-shaped Sheep Mountain in the South Unit correlate to this most ancient surface level. Possible association: Pliocene (Fremont surface)?

\section{Weathering, Mass Wasting, and Erosion}

The evolution of the landscape in Badlands National Park reflects many factors or conditions relating to bedrock and climate. The contrast in erosion styles between the marine sediments of the Pierre Shale and the overlying White River beds demonstrates that the physical and chemical properties of the bedrock are important factors in the formation of Badlands topography. The physical processes that change the landscape can be subdivided into weathering, mass wasting, and erosion.

Weathering includes the physical and chemical processes that reduce solid rock at the earth's surface into sediment. It involves mechanical weathering (disintegration of big pieces into small pieces without changing the chemical composition of the rock), and chemical weathering (the chemical decomposition of earth materials, involving a chemical or mineralogical change in composition, and reducing rock into sediment).

Mass wasting is the movement of material down an unstable slope as an effect of gravity. Erosion is simply the physical removal of sediments to other locations. Erosion of material results in deposition somewhere else. Surficial sedimentary deposits include alluvium (deposited clay, silt, sand, gravel, or similar material from running water), colluvium (sediment deposited at the base of a slope by mass wasting), and illuvium (wind-deposited sediments).

The climate of the Badlands National Park region is an important factor in reviewing weathering and erosion processes. Average rainfall is in the range of 17 inches (the range can several inches more in the higher elevations, and several inches less along the valleys). The driest period is mid winter (December and January) when rainfall is typically less than 0.3 inches. About 77 percent of the annual precipitation occurs 
in late spring and summer (April to September). Average June rainfall is in the range of 3.12 inches (based on data from Rapid City International Airport about 40 miles west of the park). This rainfall typically occurs in association with short-duration thunderstorms. Winter precipitation occurs with snowstorms that are most frequent in March. Average monthly temperatures range from a subfreezing average of 22 degrees F in January, to an average of 72 degrees in August (with daytime temperatures typically reaching the mid $90 \mathrm{~s}$ in the afternoon. The park only experiences an average of 130 frost-free days a year. The combination of high summer temperatures and short rain events, along with the dry cold winter make growing conditions difficult for most plants, particularly in the harsh, soil-free conditions in and around the badlands.

Erosion is perhaps most dramatic in the barren landscape of the badlands. Erosion rates are high in the barren landscape regions, as much as an inch of sediment per year.
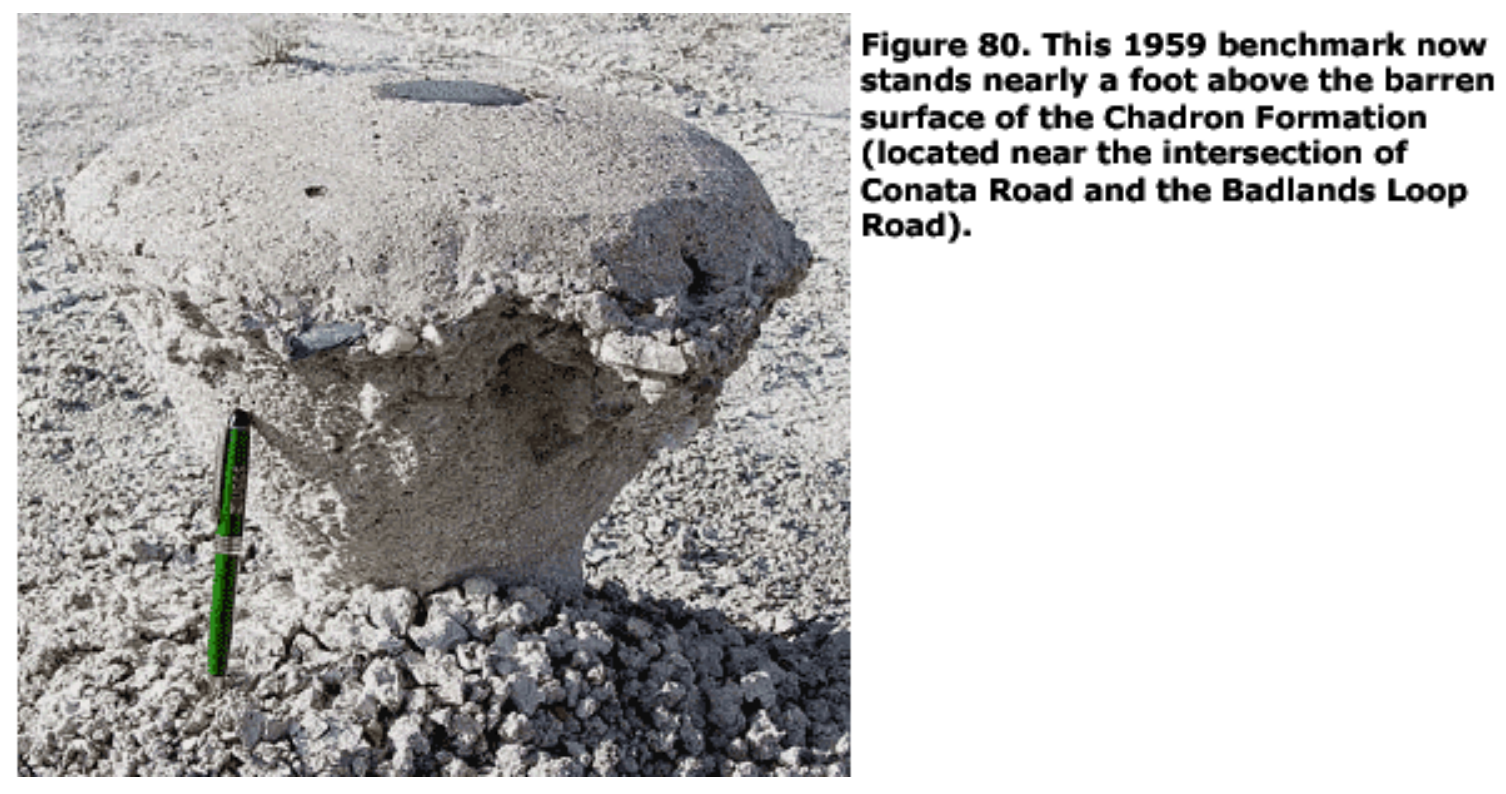

Heavy rainfall from thunderstorms has little ability to soak into the soil-free bedrock, as it flows as a sheet wash across the surface into rills (or rivulets) and then into stream channels. Mass wasting (including slumping and rock falls) contributes sediment directly to stream channels. Heavy rainfall loosens sediment. If rain falls faster that the soil or bedrock can absorb it, the water runs off, carrying along sediment. If enough rain falls, then flash floods occur. With the abundant clay, silt, and sand derived from the poorly consolidated sediments of the White River beds, the flowing water approaches maximum stream capacity (the total amount of material [load] which a stream is able to move by the combined processes of solution, suspension, and saltation).

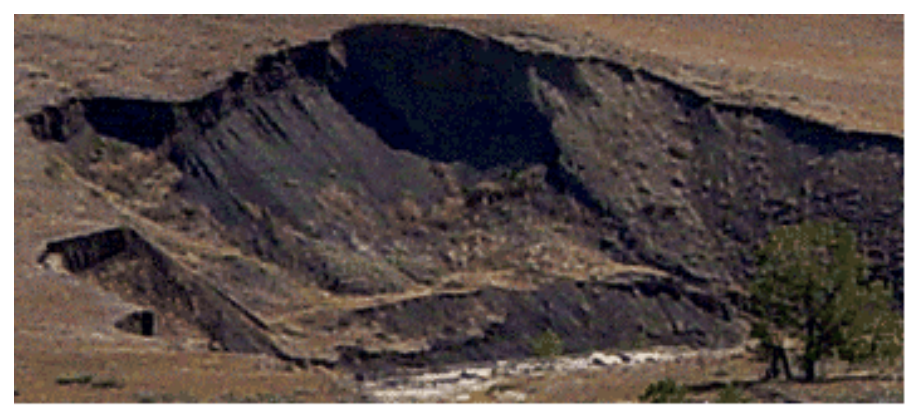

Figure 81. An active slump along Sage Creek is constantly adding new sedimentary material directly to the stream. 


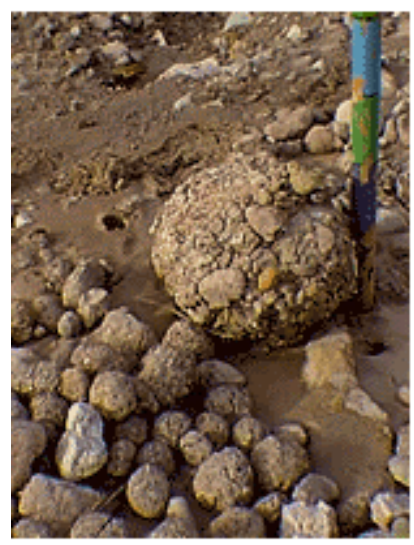

Figure 82. Armored mud balls form when chunks of clay-rich mud from the Chadron Formation fall into streams in flashflood. As the mud ball rolls downstream with the flow, the sticky clay surface picks up rocks and debris, giving it a pebble-studded surface.

\section{Castles, Monuments, Sod Tables, and Hoodoos}

Badlands National Park is best known for its scenic, rugged topography. The term badlands refers to regions of eroded land on which most of the surface is covered with ridges, gullies, and deep channels, having sparse vegetation.

Landscape features with badlands also have descriptive names, such as follows:

Castles are large star or block shaped barren badlands that are the remaining remnant of bedrock, typically located at the intersection of multiple stream drainages (see fig. 83).

A wall is another name for a linear erosional escarpment of badlands.

A monument is a lone remaining pinnacle of bedrock that rises away from other upland features (such as "walls" or "castles").

A hoodoo is a typically an inverted cone-shaped erosion remnant of sedimentary bedrock or a hard rock (sandstone) resting on a pedestal of softer material (such as clay). Hoodoos are smaller than castles or monuments, and are typically numerous in a badlands area.

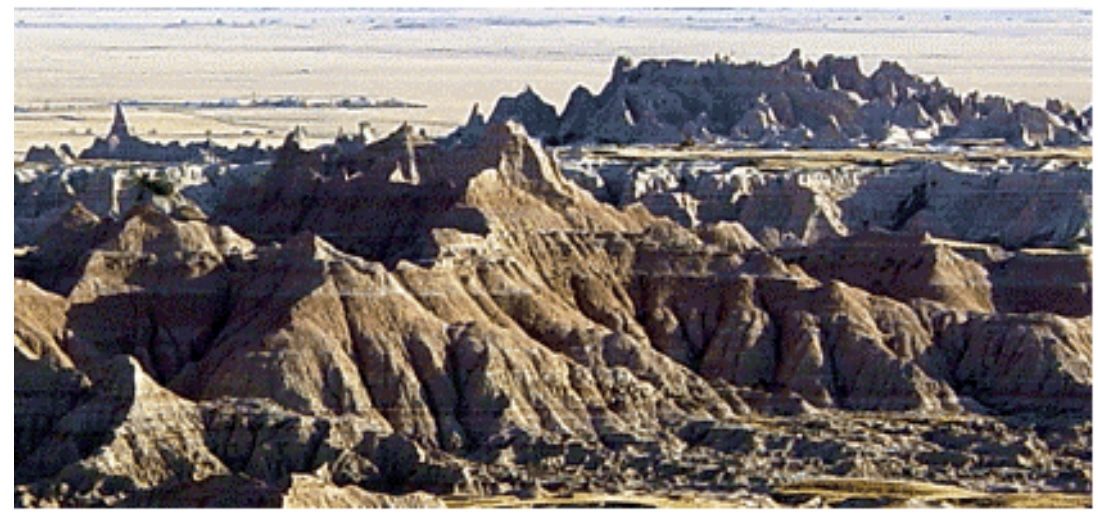

Figure 83. Castles and monuments occur throughout the region south of the High Pinnacles Overlook in Badlands North Unit.

Sod Tables are low, typically grass-covered mesas scattered in the valley bottoms between the higher castles, walls, and monuments of the badlands (fig. 84). The plateau-like grass-covered surfaces are remnants of an earlier floodplain surface (alluvial-colluvial fans) and on White River bedrock. Grasses and other plants bind a thin soil that fairly quickly gives way to erosion along expanding headwaters of new channels. Sod tables occur at several levels ranging from 0.5 to $10 \mathrm{~m}$ above channel bottoms in adjacent 
washes. The sod tables demonstrate that perhaps during a wetter period, perhaps early in the Holocene, allowed vegetation to become established. Today the region is dryer, and one the thin soil erodes away only barren badlands remain, and are prone to more intense erosion particularly during infrequent by heavy precipitation during summer seasonal storms.
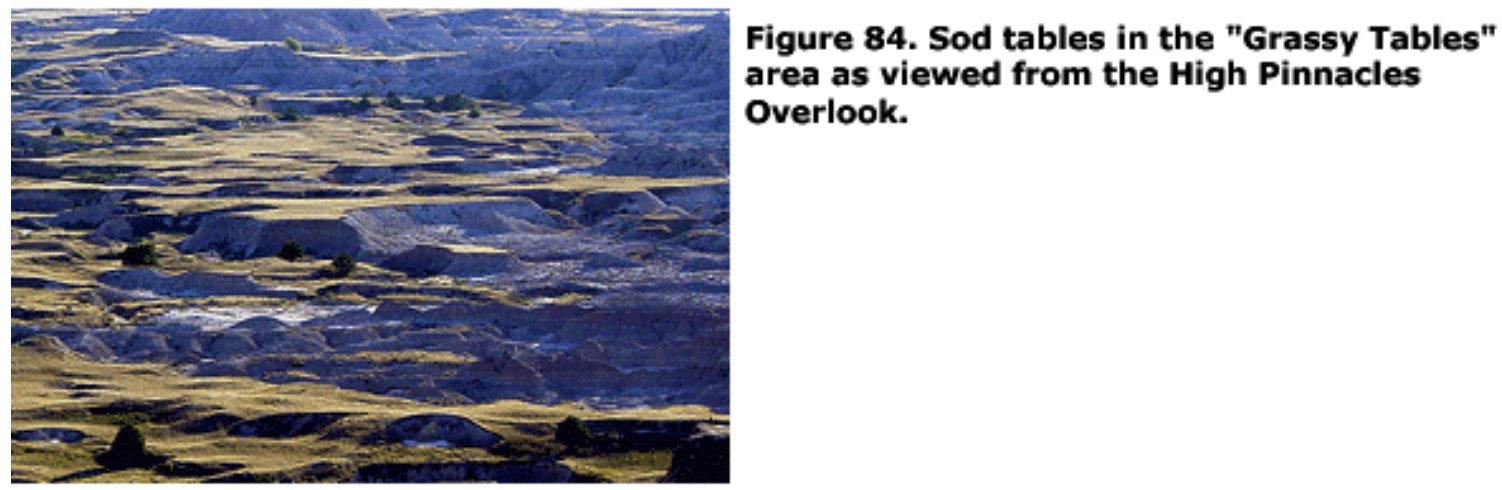

\section{Acknowledgments}

This investigation began with support form a U.S. Geological Survey EDMAP grant in support of stratigraphic research focused on the Sage Creek Wilderness Area of the North Unit of Badlands National Park. This research, partially supported by a U.S. Geological Survey EDMAP grant, is a follow-up to investigations to dissertation research (Stoffer, 1998 and Terry, 1998.) This research is a cooperative effort involving the authorities of the National Park Service, the U.S. Geological Survey, the South Dakota Geological Survey, and CUNY, Brooklyn College, Department of Geology.

\section{Selected Internet Links}

Badlands National Park website: hittp://Www.nps.gov/badl//i

Badlands National Park, USGS-NPS Vegetation Mapping Program Products: This website includes aerial photography_and information on climate, soils, Wildlife and vegetation:

http://biology.usgs.gov/npsveg/badl/l.

Ecoregions of North Dakota and South Dakota. ${ }_{2}$ 3. Northwestern Great Plains:

http://www.npwrc.usgs.gov/resource/1998/ndsdeco/43h.htm.

Stoffer, P., P. Messina, J. A. Chamberlain, Jr., D.O. Terry, Jr. 2001, The Cretaceous-Tertiary Boundary Interval in Badlands__National Park,__South Daknota:___.S._. Geological Survey Open-File Report 01-056, online at: http://geopubs. wr.usgs.gov/open-file/of01-056/.

\section{Selected references}

Agnew, A.F., and P.C. Tychsen, 1965, A Guide to the Stratigraphy of South Dakota: South Dakota State Geological Survey Bulletin 14, 195 p.

Blackwelder, E., 1915, Post-Cretaceous history of the mountains of central western Wyoming, Parts I, II, and III: Journal of Geology, v. 23, p. 97-116, 193-216, 306-330 
Bump, J.D., 1956, Geographic names for members of the Brule Formation of the Big Badlands of South Dakota: American Journal of Science, v. 254, p. 429-432.

Cobban, W.A., 1958, Two new species of baculites from the Western Interior Region: Journal of Paleontology, v. 32, p. 660-665.

Cobban, W.A., 1962, Baculites from the Bearpaw Shale and equivalent rocks of the Western Interior: Journal of Paleontology, v. 36, p. 126-135.

Crandell, D.R., 1958, Geology of the Pierre area, South Dakota: U.S. Geological Survey Professional Paper 307.

Clark, J., 1954, Geographic designation of the members of the Chadron Formation in South Dakota: Carnegie Museum Annals, v. 33, p. 197-198.

Darton, N.H., 1896, Preliminary report on artesian waters of a portion of the Dakotas: U.S. Geological Survey $17^{\text {th }}$ Annual Report, pt. 2, p. 609-694.

Darton, H.H., 1899, Part 4; Preliminary report on the geology and water resources of Nebraska west of the one hundred and third meridian: U.S. Geological Survey $19^{\text {th }}$ Annual Report, Pt. 4, p. 736, 755-759.

Elias, M.K., 1933, Cephalopods of the Pierre Formation of Wallace County, Kansas, and adjacent areas. University of Kansas Science Bulletin (Lawrence) v. 21, p. 289-363.

Gill, J.R. and W.A. Cobban, 1966, The Red Bird Section of the Upper Cretaceous Pierre Shale in Wyoming: U. S. Geological Survey Professional Paper 393-A.

Gill, J.R. and W.A. Cobban, 1973, Stratigraphy and Geologic History of the Montana Group and Equivalent Rocks, Montana, Wyoming, North and South Dakota: U. S. Geological Survey Professional Paper 776.

Hall, J. and F.B. Meek, 1854, Memoir of the Academy of Arts and Sciences (Boston) (new series), v. 5, p. 396.

Hancock, G. S. and R. S. Anderson, 2002, Numerical modeling of fluvial terrace formation in response to oscilating climate. GSA Bulletin, v. 114, p. 1131-1142.

Harksen, J.C., J.R. Macdonald, and W.D. Sevon, 1961, New Miocene formation in South Dakota: American Association of Petroleum Geologists Bulletin, v. 45, p. 674-678.

Hayden, F.V., 1857, Notes on the Geology of the Mauvaises Terres of White River, Nebraska: Proceedings of the Academy of Natural Sciences of Philadelphia, v. 9, p. 151-158.

Kennedy, W.J., N.H. Landman, W.K. Christiansen, W.A Cobban, and J.M. Hancock, 1998, Marine connections in North America during the late Maestrichtian: palaeogeographic and palaeobigeographic significance of Jeletzkeytes nebrascensis Zone cephalopod fauna from the Elk Butte Member of the Pierre Shale, South Dakota and NE Nebraska: Cretaceous Research, v. 19, p. 745-775.

Landman, N.H. and K.M. Waage, 1993, Scaphitid ammonites of the Upper Cretaceous (Maestrichtian) Fox Hills Formation in South Dakota and Wyoming: Bulletin of the American Museum of Natural History, v. $215,257 \mathrm{p}$.

Meek, F.B. and F.V. Hayden, 1856, Descriptions of new species of gastropods and cephalopods from the Cretaceous formations of Nebraska Territory. Proceedings of the Academy of Science of Philadelphia, v. 8, p. 63-126. 
Meek, F.B. and F.V. Hayden, 1857 [1858], Descriptions of new species and genera of fossils, collected by Dr. F. V. Hayden in Nebraska Territory; with some remarks on the Tertiary and Cretaceous formations of the Northwest: Proceedings of the Academy of Natural Sciences of Philadelphia, v.1857, pp.117-148.

Meek, F.B. and F.V. Hayden, 1861 [1862], Descriptions of new Lower Silurian (Primordial), Jurassic, Cretaceous, and Tertiary fossils collected in Nebraska by the exploring expedition under the command of Captain W. F. Reynolds, U.S. Topographical Engineer, with some remarks on the rocks from which they were obtained. Philadelphia Academy of Natural Sciences Proceedings, v. 13, p. 414-447.

Meek, F.B., 1876, Report on p. 1xi-lxiv, In A report on the invertebrate Cretaceous and Tertiary fossils of the upper Missouri country: U.S. Geological and Geographical Survey of the Territories (Hayden Survey) Monograph 9, [629 p.]

Morton, R.A., 1988, Near-shore responses to great storms: Geological Society of America Special Paper 229 , p. 7-20.

National_Park Service ${ }_{2}$ Badlands_____ational_Park (no date): The Pig Dig [website]: http://www.nps.gov/badl/brochures/pigdig.pdf

Nicknish, J.M. and J.R. Macdonald, 1962, Basal Miocene ash in White River Badlands, South Dakota: American Association of Petroleum Geologists Bulletin, v. 46, p.685-690.

O'harra C.C., 1920, The White River Badlands: South Dakota School of Mines (Department of Geology), Bulletin No. 13, 181 p.

Owen, D.D., 1852, Report of a Geological Survey of Wisconsin, Iowa, and Minnesota and Incidentally of a Portion of Nebraska Territory. Philadelphia, Pa: Lippincott, Grambo and Co.

Pettijohn, W.A., 1965, Eocene soil profile in the northern Great Plains: Proceedings of the South Dakota Academy of Science, v. XLIV, p. 80-87.

Pettijohn, W.A., 1966, Eocene paleosol in the northern Great Plains: U. S. Geological Survey Professional Paper 550-C, p. 61-65.

Pettijohn, W.A., 1967, New members of Upper Cretaceous Fox Hills Formation in South Dakota, representing delta deposits. American Association of Petroleum Geologists Bulletin, v. 51, p. 1361-1367.

Raymond, W.H. and U.R. King, 1976, Geologic Map of the Badlands National Park and Vicinity, WestCentral South Dakota: U.S. Geological Survey Miscellaneous Investigations Series Map I-934; scale 1:62,000.

Retallack, G.J., 1983, Late Eocene and Oligocene paleosols from Badlands National Park, South Dakota: Geological Society of America Special Paper 193, 82 p.

Robinson, C.S., W.J. Mapel and W.A. Cobban, 1959, Pierre Shale along western and northern flanks of Black Hills, Wyoming and Montana: Bulletin of the American Association of Petroleum Geologists, v. 43, p. 101-123.

Rubey, W.W., 1930, Lithologic studies of fine-grained upper Cretaceous sedimentary rocks of the Black Hills region: In Shorter Contributions to General Geology, 1930: U.S. Geological Survey Professional Paper 165-A, p. 3-4.

Say, T., 1820, Observations on some species of zoophytes, shells, etc., principally fossil: American Journal of Science, $1^{\text {st }}$ Ser. v. 2, p. 34-45. 
Searight, W. V. 1937. Lithologic stratigraphy of the Pierre Formation of the Missouri Valley in South Dakota: South Dakota Geological Survey, Report of Investigations no. 27.

Stoffer, P.W., 1998. Stratigraphy of the Upper Pierre Shale and Fox Hills Formation (Campanian and Maestrichtian; Late Cretaceous) in the Badlands National Park Region, South Dakota: Implications for Eustatic Changes in Sea Level, Tectonism, and Marine Paleoecology of the Western Interior Seaway: City University of New York, PhD dissertation, 499 p.

Stoffer, P.W., P. Messina and J.A. Chamberlain, Jr., 1997, Buried slumps in the upper

Pierre Shale/Fox Hills transition interval in Badlands National Park: Geological Society of America, Annual Meeting abstract.

Stoffer, P.W., P. Messina and J.A. Chamberlain, Jr., 1998, Upper Cretaceous stratigraphy of Badlands National Park, South Dakota: Influence of tectonism and sea level change on sedimentation in the Western Interior Seaway: Dakotaterra, v. 5, p. 55-62.

Stoffer, P.W., P. Messina, J.A. Chamberlain, Jr., and D.O. Terry, Jr., 2001, The Cretaceous-Tertiary Boundary Interval_in_Badland_ National_Park,_South_Dakota: U_.S. Geological Survey Open-File Report 01-056, online at: htttp://geopubs.wr.usgs.gov/open-file/of01-056/.

Terry, D.O, J.A. Chamberlain, Jr., P. Stoffer, P. Messina, P.A. Jannett, 2001, Marine Cretaceous-Tertiary boundary section is southwestern South Dakota: Geology, v. 29, no. 11, p. 1055-1058.

Terry, D.O., Jr., (editor), 1998, Depositional Environments, Lithostratigraphy, and Biostratigraphy of the White River and Arikaree Groups (Late Eocene to Early Miocene, North America: Geological Society of America Special Paper 325, 216 p.

Terry, D.O. and J.E. Evans, 1994, Pedogenesis and paleoclimatic implications of the Chamberlain Pass Formation, Basal White River Group, Badlands of South Dakota: Palaeogeography, Palaeoclimatology, Palaeoecology, v. 110, p.197-215.

Waage, K.M., 1968, The Type Fox Hills Formation, Cretaceous (Maestrichtian), South Dakota, part 1, Stratigraphy and Paleoenvironments: Peabody Museum Natural History Bulletin no. 27, 171 p.

Wanless, H.R., 1923, untitled discussion: American Philosophical Society Proceeding, v. 62, p. 194.

Ward, F., 1926, untitled discussion: American Journal of Science, $5^{\text {th }}$ Series, v. 2, p. 350-352.

Ward F., 1922, Geology of a portion of the Badlands: South Dakota Geological and Natural History Survey Bulletin, v. 11, p. 18-20.

Wood, R.A., 1999, The weather almanac: a reference guide to weather, climate, and air quality in the United States and its key cities, comprising statistics, principles, and terminology, $9^{\text {th }}$ edition: Detroit, Michigan: Gale Research Co.

Wortman, J.L., 1893, On divisions of the White River of Lower Miocene of Dakota: American Museum of Natural History Bulletin, v. 5, p. 95-105. 